ISSN impresso: $1677-1303$ ISSN eletrônico: 1983-9294

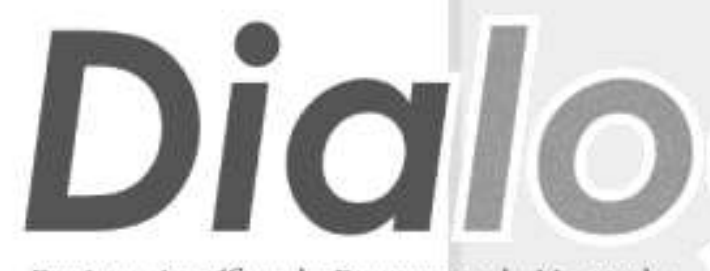

Revista científica do Programa de Mestrado em Gestào e Práticas Educacionais - PROGEPE

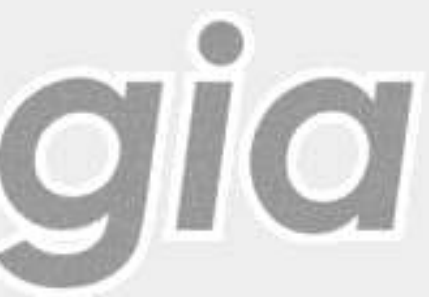

dialogia@uninove.br www.uninove.br/revistaDialogia 
C 2018 - Universidade Nove de Julho (Uninove)

dialogia@uninove.br www.uninove.br/revistadialogia Endereço para correspondência Universidade Nove de Julho (UNINOVE) Rua Vergueiro no 235/249, 12 andar - Liberdade, São Paulo, SP, Brasil, CEP 01504-001.

Telefone: +55 (11) 3385-9191

\section{Afiliada}

Abec - Associação Brasileira de Editores Científicos www.abecbrasil.org.br Membro

Clacso - Conselho Latino-americano de Ciências Sociais. http://www.clacso.org Fepae - Fórum dos Editores de Periódicos da Área da Educação, da Associação Nacional de Pós-graduação e Pesquisa em Educação Anped Bases indexadoras

BBE - Bibliografia Brasileira de Educação - MEC/INEP.

http://pergamum.inep.gov.br/pergamum/biblioteca/index.php?resol ution2=1024_1

Clarivate Analytics - http://mjl.clarivate.com/cgi-

bin/jrnlst/jlresults.cgi?PC=MASTER\&Word=Dialogia

CREDI - Centro de Recursos Digitais da Organização dos Estados

Ibero-Americanos (OEI).

http://www.oei.es/historico/br146.htm

DOAJ - Directory of Open Access Journals.

https://doaj.org/toc/1983-9294

EBSCO - Academic Databases for Colleges and Universities.

https://www.ebscohost.com/titleLists/aph-journals.htm

ERIH PLUS - Índice Europeu de Referência para as Humanidades (ERIH PLUS).

https://dbh.nsd.uib.no/publiseringskanaler/erihplus/periodical/info?i $\mathrm{d}=485776$

IRESIE - Base de datos sobre Educación - IISUE, UNAM

Latindex - Sistema Regional de Información em Línea para Revistas

Científicas de América Latina, el Caribe, España y Portugal.

http://www.latindex.unam.mx/latindex/ficha?folio=17561

OAJ - http://oaji.net/journal-detail.html?number $=4613$

REDIB - Red Iberoamericana de Innovación y Conocimiento Científico. https://redib.org/recursos/Record/oai_revista1099-dialogia ROAD - Directory of Open Access Scholarly Resources. http://road.issn.org/en $-$

Universidade Nove de Julho Reitoria: Eduardo Storópoli

Pró-Reitoria Acadêmica: Maria Cristina B. Storópoli Pró-Reitoria Administrativa: Jean Anastase Tzortzis Pró-Reitorias de campus: Claudio Ramacciotti Diretoria de Pesquisa: João Carlos Ferrari Corrêa Diretoria do Programa de Mestrado em Gestão e Práticas Educacionais (PROGEPE): Jason Ferreira Mafra

www.uninove.br

\section{UNINOVE}

Dialogia é uma publicação científica quadrimestral do Programa de Mestrado em Gestão e Práticas Educacionais (PROGEPE) que se propõe a debater e divulgar os temas relativos às práticas educacionais e ao pensamento pedagógico, especialmente os que resultam das pesquisas realizadas no âmbito dos programas de pós-graduação stricto sensu, nacionais e estrangeiros. Os seus destinatários são, prioritariamente, professores, pesquisadores, estudantes e todo o público que, direta ou indiretamente, mantêm interesse nas questões educacionais.

Dialogia is a quarterly scientific publication of the Master's Degree Program in Management and Educational Practices (PROGEPE) that proposes to discuss and to become known the themes concerning educational practices and pedagogical thinking specially those that result from researches carried out within the post-graduation nationals and foreign stricto sensu programs. Their receivers are primarily teachers, researchers, students and all kind of public that, directly or indirectly, keeps interest in educational issues.

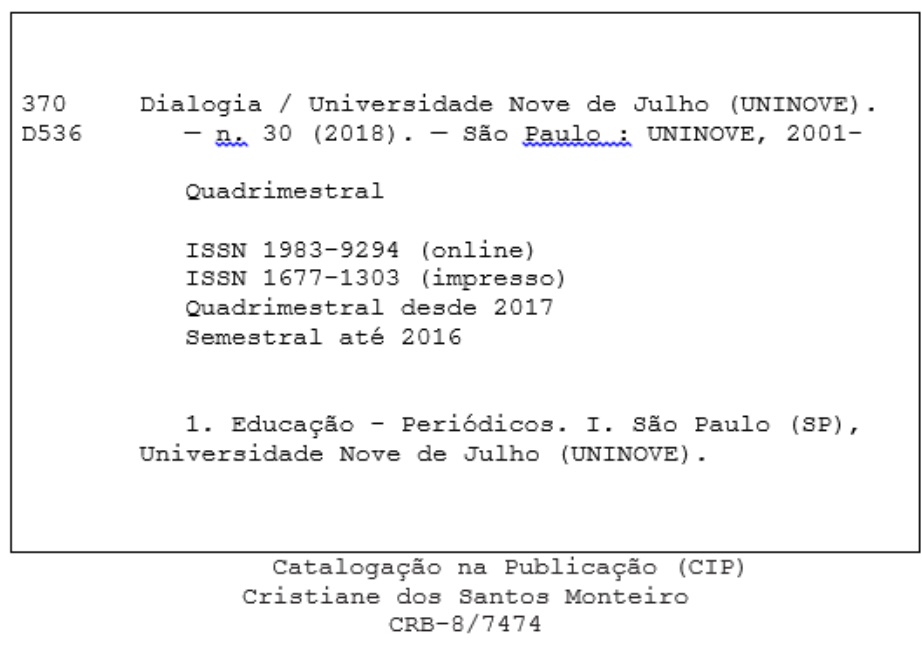

A instituição ou qualquer dos organismos editoriais desta publicação não se responsabiliza pelas opiniões, ideias e conceitos emitidos nos textos, os quais são de inteira responsabilidade de seu(s) autor(es). 


\section{Comissão Editorial}

Ana Maria Haddad Baptista (editora)

Márcia Fusaro (editora)

Jason Ferreira Mafra

Rosemary Roggero

\section{Conselho Editorial}

Adriana Salete Loss - Universidade Federal da Fronteira Sul [Brasil]

Afonso Celso Scocuglia - Universidade Federal da Paraíba [Brasil]

Ana Luisa Janeira - Universidade de Lisboa [Portugal]

António Teodoro - Universidade Lusófona de Humanidades e Tecnologias [Portugal]

Carlos Bauer - Universidade Nove de Julho [Brasil]

Carlos Rodrigues Brandão - Universidade Estadual de Campinas [Brasil]

Celso de Rui Beisiegel - Universidade de São Paulo [Brasil]

Cleiton de Oliveira - Universidade Metodista de Piracicaba [Brasil]

Daniel Carceglia - Universidad Nacional de Quilmes [Argentina]

Edgar Pereira Coelho - Universidade Federal de Viçosa [Brasil]

Genoino Bordignon - Universidade de Brasília [Brasil]

Guillermo Williamson - Universidade La Frontera [Chile]

João Cardoso Palma - Universidade Estadual Paulista [Brasil]

José Amilcar de Carvalho Coelho - Universidade Nova de Lisboa [Portugal]

Luciana P. Marques - Universidade Federal de Juiz de Fora [Brasil]

Luiza Cortesão - Universidade do Porto [Portugal]

Maria Manuela Duarte Guilherme - Universidade de Coimbra [Portugal

Marcella Milana - Universidade de Copenhague [Dinamarca]

Maria Stela Santos Graciani - Pontifícia Universidade Católica-SP [Brasil]

Miguel Escobar Guerrero - Universidad Nacional Autónoma de México [México]

Nilce da Silva - Universidade de São Paulo [Brasil]

Patrícia J. Grandino - Universidade de São Paulo-Leste [Brasil]

Peter Lownds - Paulo Freire Institute [EUA]

Ramon Moncada - Corporación Región [Colômbia]

Ubiratan D'Ambrósio - Universidade de São Paulo [Brasil]

Walter E. Garcia - Instituto Paulo Freire [Brasil]

\section{Equipe editorial}

Juliana Cezario

João Ricardo M. Oliveira

Cristiane dos Santos Monteiros 


\section{Pareceristas ad hoc -2018}

Angela Di Paolo Mota - Instituto Singularidades, São Paulo, SP - Brasil

Catarina Justus Fischer - São Paulo, SP - Brasil

Clóvis Da Rolt - Universidade Federal do Pampa, Jaguarão, RS - Brasil

Diana Navas - Pontifícia Universidade Católica de São Paulo, São Paulo, SP - Brasil"

Dirceu Benincá - Universidade Federal do Sul da Bahia, Teixeira de Freitas, BA - Brasil

Edielso Manoel Mendes Almeida - Pontifícia Universidade Católica de São Paulo, São Paulo, SP- Brasil

Isabel Jungk - Pontifícia Universidade Católica de São Paulo,São Paulo, SP - Brasil

Manuel Tavares - Universidade Nove de Julho, São Paulo, SP - Brasil

Monica Avila Todaro - Universidade Federal de São João del-Rei, São João del-Rei, MG Brasil

Patrícia Fonseca Fanaya - Universidade Federal de Santa Catarina, Florianópolis, SC - Brasil

Rodrigo Fontanari - Universidade de Sorocaba, Sorocaba, SP - Brasil

Rosemary Roggero - Universidade Nove de Julho, São Paulo, SP - Brasil

Tarcísio de Sá Cardoso Universidade Federal da Bahia, Salvador, BA - Brasil

Valdir Carlos Silva - Instituto Superior de Educação de São Paulo, São Paulo, SP - Brasil

Vanessa Beatriz Bortulucce - Universidade São Judas Tadeu, São Paulo, SP - Brasil

Ligia de Carvalho Abões Vercelli - Universidade Nove de Julho, São Paulo, SP - Brasil

Rosiley Aparecida Teixeira - Universidade Nove de Julho, São Paulo, SP - Brasil

Roberto Cezar Bianchini - Universidade Anhembi Morumbi, São Paulo, SP - Brasil

Paula Cristina David Guimarães - Universidade Federal de São João del Rei, São João delRei, MG - Brasil

Débora de Freitas Ramos - Universidade do Estado do Rio de Janeiro, Rio de Janeiro, RJ Brasil

Maurício Pedro da Silva - Universidade Nove de Julho, São Paulo, SP - Brasil

Maria Aparecida Costa dos Santos - Prefeitura Municipal de São Paulo, São Paulo, SP Brasil

Tatiana Pinheiro de Assis Pontes - Universidade Federal de São João del-Rei, São João delRei, MG - Brasil

Elizabeth dos Reis Sanada - Instituto Singularidades, São Paulo, SP - Brasil

Genilda Azeredo - Universidade Federal da Paraíba, Paraíba, PA - Brasil 


\section{Sumário/ Contents}

Editorial / Editor's note

Da Educação e da Literatura.

Ana Maria Haddad Baptista e Márcia Fusaro

\section{Entrevista / Interview}

Dos livros, da leitura, da literatura, Entrevista com o professor Clóvis Da Rolt.

Dossiê Temático: Educação e literatura / Thematic dossier: education and literature

Drummond e o engajamento literário

Drummond and the literary engagement

Cristiano Perius

As poéticas de cuidado com o meio ambiente na literatura infantil e juvenil

brasileira

The poetics of environmental care in brazilian children's and young literature

Eliane Santana Dias Debus

José Carlos dos Santos Debus

Entre margens: Guimarães Rosa Na Sala de Aula.

Between the Margins: Guimarães Rosa in the Classroom

Júlio de Souza Vale Neto

Lara Silva Perussi Bertão

Nayra Mikie Dias Kikuchi

Ensino de história, planejamento e autoria: experimentações com literatura negra em estágios curriculares obrigatórios.

Teaching history, planning and authorship: experiments with black literature in compulsory curricular stages

Carla Beatriz Meinerz

Fernanda Amorin Golembiewski

Raisa da Silva Oyarzabal

Cecília Meireles e sua atuação política na educação brasileira: literatura, jornalismo e feminino.

Cecília Meireles and his political action in Brazilian Education: literature, journalism and women

Nubea Rodrigues Xavier

Magda Sarat

Artigos / Articles

Infusing an international online learning experience into the curriculum: a United States and Mexico collaboration

Infundindo uma experiência de aprendizagem internacional online no currículo: uma colaboração entre Estados Unidos e México

Flavia Iuspa

O potencial transformador da arte: um diálogo entre Vigotski e Antonio Candido

The transformational potential of art: a Vigotski and Antonio Candido dialogue

Denise Stefanoni Combinato

Escola e interculturalidade: elementos para pensar a diversidade no currículo

School and interculturality: Elements to think diversity in the curriculum

Luciana Pacheco Marques

Gabriela Silveira Meireles

Vamos brincar na terra? uma experiência de valorização e resgate da cultura infantil com moradores da comunidade de Arraiol na Amazônia Amapaense.

Are we going to play on Earth? an experience of valuing and rescuing children's culture with residents of the community of the Amapaense Amazon Priscilla Pantoja do Nascimento Brandão

Ângela do Céu Ubaiara Brito 
A escolha profissional na perspectiva do estudante do ensino técnico de nível médio

Professional choice in the perspective of the high school technical education student

Nonato Assis de Miranda

Mateus Reis Santos

Arcy Pires Piagetti Junior

Rompendo os muros escolares

Breaking the school walls

Adriana Salete Loss

Por um currículo plural na perspectiva do multiculturalismo

For a pluralistic curriculum in the perspective of multiculturalism

Maria das Graças Gonçalves Vieira Guerra

Iracema Campos Cusati

Kleber Ferreira Costa

\section{Resenhas/ Reviews}

Formação de Professores no Brasil: leituras a contrapelo

de Olinda Evangelista e Allan Kenji Seki (Org.)

Eudite Fernandes Carneiro

.Instruções para os autores/ Instructions for authors

Orientações para submissão de trabalhos à revista

Dialogia...... 


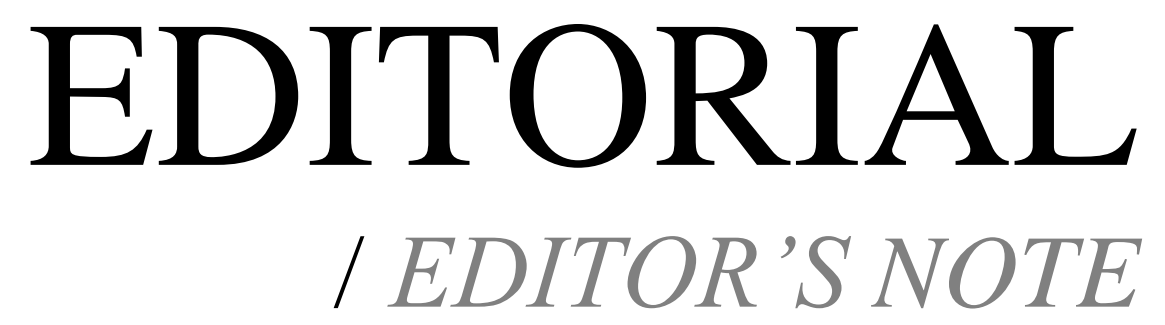





\section{Da Educação e da Literatura}

A edição no. 30 da Revista Dialogia, Educação e Literatura, traz uma entrevista com o poeta, ensaísta e professor Clóvis Da Rolt. Entre tantas outras coisas que poderiam ser destacadas, o professor enfatiza a importância da literatura enquanto uma ferramenta feroz de abertura para novos saberes, assim como o aspecto interdisciplinar que a leitura possibilita em todos os graus. Não deixa de observar o quanto as escolas, em geral, na maioria das vezes, esquecem que a literatura deveria ser um verdadeiro suporte para se repensar novas formas de existência, experiências.

No dossiê destacamos o texto Drummond e o engajamento literário em que a autora analisa o olhar social do poeta mineiro, tendo como fundamentação teórica Sartre, no que diz respeito da literatura, intrinsecamente, estar comprometida com a sociedade de sua época, ao mesmo tempo em que contrapõe Merleau-Ponty sob um olhar diferente, ou seja, a partir do interior da obra poética. As poéticas de cuidado com o meio ambiente na literatura infantil e juvenil brasileira possibilita um diálogo esclarecedor no que diz respeito aos cuidados que os tempos atuais exigem da humanidade por meio de narrativas dirigidas ao público infantil.

O artigo Entre margens: Guimarães Rosa na Sala de Aula é uma contribuição valiosa no que diz respeito à literatura. A proposta dos autores é analisar o famoso conto do autor mineiro "A Terceira Margem do Rio" enquanto uma leitura introdutória de Guimarães para o ensino médio. Nessa medida, destaca o quanto uma literatura universal e de real valor pode ser possível, inclusive, para aqueles que estão em fase de amadurecimento, para outras leituras do autor, assim como para aquelas leituras que precisam de um repertório para compreender a poética literária. O texto Ensino de História, Planejamento e Autoria: experimentações com literatura negra em estágios curriculares obrigatórios faz uma análise significativa ao analisar o papel do professor autor. Ou seja, propõe que as aulas de história dialoguem com as teorias propostas pela área juntamente com a literatura que foca o negro em estágios curriculares obrigatórios entre história e culturas africanas. Cecília Meireles e sua atuação política na educação brasileira: Literatura, Jornalismo e Feminisno é um artigo faz uma análise detalhada entre a vida e formação da escritora. Desta maneira, evidencia o legado que conjuga literatura, política e educação.

Os artigos que se seguem ao dossiê analisam diferentes questões de grande interesse para a área da Educação. Note-se a importante contribuição de Flavia Iuspa Correio da 
Florida International University. A pesquisadora destaca, entre outras coisas, questões de perspectivas múltiplas para encontrar soluções efetivas diante de problemas globais. Há uma análise de experiências internacionais de aprendizado que estende nossa consciência a respeito da diversidade cultural que povoa o globo. O texto $O$ potencial transformador da arte: um diálogo entre Vigotski e Antonio Candido faz uma análise importante sobre o papel transformador da arte ao mostrar o quanto a estética humaniza e adensa os sentidos.

Escola e interculturalidade: elementos para pensar a diversidade no currículo pode ser uma perspectiva diferenciada e mais abrangente para se refletir a educação dentro de um sistema global capitalista. Nessa medida, o artigo contraria o famoso discurso etnocêntrico. Vamos brincar na terra? Uma experiência de valorizaçãa e resgate da cultura infantil com moradores da comunidade de Arraiol na Amazônia Amapaense é um texto que discute o brincar ribeirinho na comunidade de Arraiol. Demonstra o quanto as brincadeiras infantis são importantes para compreender as crianças e o quanto as práticas sociais influenciam o comportamento das mesmas.

A escolha profissional na perspectiva do Estudante do Ensino Técnico de Nivel Médio é significativo, à medida que abre um espaço de reflexão, de caráter qualitativo, para professores que lecionam a estudantes de ensino médio. Rompendo os muros escolares possui como tema central a discussão dos processos educacionais escolares levando em consideração a reflexão sobre as práticas pedagógicas monoculturais e hegemônicas. Por um currículo plural na perspectiva do multiculturalismo é um texto que tem como centro a discussão do conceito de multiculturalismo. Neste artigo há uma reflexão significativa que envolve, inclusive, a formação de professores.

A resenha da coletânea Formação de Professores no Brasil: leituras a contrapelo reúne textos de pesquisadores ligados ao Grupo de Estudos sobre Política Educacional e Trabalho da Universidade Federal de Santa Catarina.

Boa leitura a todos, Ana Maria Haddad Baptista

Márcia Fusaro

as editoras 


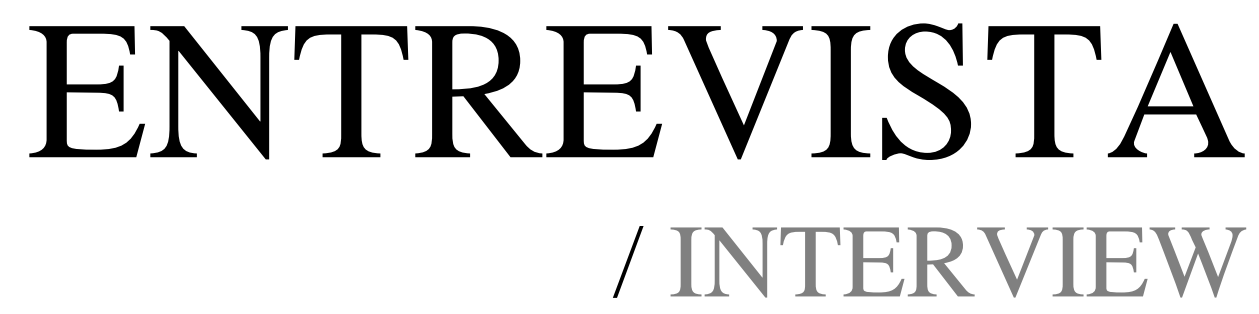





\section{Dos livros, da leitura, da literatura, Entrevista com o professor Clóvis Da Rolt}

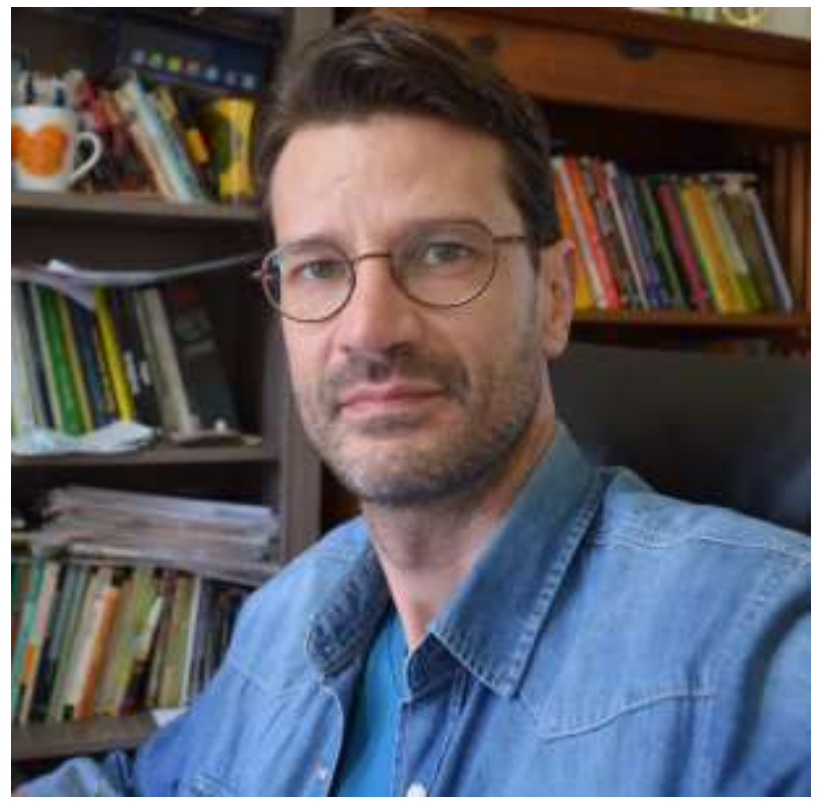

Docente na Universidade Federal do Pampa (UNIPAMPA), Campus Jaguarão-RS. Possui graduação em Licenciatura Plena em Artes Plásticas (Universidade de Caxias do Sul), Especialização em Ética e Filosofia Política (Universidade de Caxias do Sul), Mestrado em Ciências Sociais (Universidade do Vale do Rio dos Sinos) e Doutorado em Ciências

Sociais (Universidade do Vale do Rio dos Sinos). Realizou período de estudos de doutorado na Faculdade de Belas Artes da Universidade de Granada (Espanha), mediante bolsa do Programa de Formação Permanente da Fundación Carolina e Junta de Andaluzia.

Atua no campo das Artes Visuais e da Antropologia com especial interesse nos seguintes temas: história e teoria das artes visuais, arte-educação, antropologia cultural e estudos do imaginário.

Dialogia: Poderia elaborar um breve relato de seu percurso profissional?

Clóvis Da Rolt: Comecei a trabalhar muito cedo, aos quatorze anos de idade. Após diversas experiências profissionais, concluí o curso de Licenciatura em Artes Plásticas, o que me levou a atuar com arte-educação (em escola, curso técnico e casa de cultura). Alguns anos depois, ingressei numa especialização em Filosofia e prossegui os estudos com o mestrado e o doutorado em Ciências Sociais. Por algum tempo fui também colunista de um jornal na minha cidade natal, Bento Gonçalves-RS. Atualmente, sou professor da Universidade 
Federal do Pampa (UNIPAMPA) - Câmpus Jaguarão-RS, onde leciono disciplinas no campo da arte e da antropologia.

No que concerne à literatura, publiquei um livro de poemas em 2004, Canção de vidro. Em 2006, como integrante de um grupo, surgiu a coletânea Calendário - Antologia poética do Grupo Neblina. Após um hiato, em 2014 publiquei um livreto-experimento intitulado Universo. Em 2016 saiu meu trabalho mais recente em poesia, o livro $A$ orientação das serpentes, que foi finalista do Prêmio Açorianos de Literatura (Porto Alegre-RS).

\section{Dialogia: As bibliotecas passam por grandes transformações. Qual sua posição diante das mudanças? Quais gostaria de destacar?}

Clóvis Da Rolt: Creio que há mudanças salutares, como aquelas que olham com mais atenção para os leitores com necessidades especiais e para as novas plataformas de leitura. Vale destacar também a atenção que algumas bibliotecas têm dado à formação de leitores, especialmente em relação às crianças, já que este público, quando exposto a uma formação leitora qualificada, pode representar a continuidade de algumas propostas futuras.

Acho interessantes as iniciativas de algumas bibliotecas que operam numa lógica de convergência, ou seja, que constroem espaços para múltiplas experiências culturais e de sociabilidade. Penso, por exemplo, em bibliotecas que não acolhem exclusivamente a cultura escrita, mas também oferecem aos frequentadores espaços como galerias de arte, salas de cinema, filmotecas, ciclos de palestras, cursos diversos, etc.

Parece-me que a nossa época apresenta uma tendência à convergência, no sentido de que se possa extrair o máximo de experiências de um único contexto/lugar. Todavia, mesmo que uma biblioteca esteja formatada como um espaço supertecnológico, multissensorial e diversificado em seu repertório de "serviços", a leitura segue sendo algo muito pessoal: a elaboração íntima de um sujeito que quer se conhecer e conhecer o mundo. Evidentemente, tal elaboração também é possível em espaços mais tradicionais, dependendo do perfil do leitor.

Em alguns casos, devido à ânsia de atualização operada por modismos, há bibliotecas demasiadamente preocupadas com uma cosmética espacial e com a criação de uma atmosfera "descolada" e agradável aos leitores, o que pode gerar uma noção de que a leitura é sempre fácil, blasé e prazerosa como uma ida ao shopping center. Ler, ler verdadeiramente, ler em profundidade, ler com entrega e afinco é um aprendizado que vem com o tempo, instala-se aos poucos, cria camadas de aprimoramento. Isso nem sempre é 
prazeroso e agradável. É para o implemento deste aprendizado que as bibliotecas devem nos auxiliar.

\section{Dialogia: Qual o papel principal das instituições escolares em relação a leituras?}

Clóvis Da Rolt: São muitos os papéis desempenhados pelas instituições escolares no que se refere à leitura, tanto para promovê-la quanto para torná-la algo insuportável e maçante. Grandes paixões pela leitura podem ser construídas na escola. E grandes decepções também. O principal papel, inicialmente, está relacionado a uma alfabetização consistente, na idade certa, capaz de desenvolver ao máximo as competências leitoras dos alunos (leitura do texto, leitura do mundo, leitura de si mesmo no texto e no mundo). Não há leitor verdadeiramente formado que não tenha passado por uma sólida proposta alfabetizadora.

Penso que as escolas devem ser promotoras da leitura. Isso equivale a dizer que elas devem ter bibliotecas frequentadas; investir em metodologias de trabalho que incluam o livro e a leitura no cotidiano dos alunos; oportunizar a formação continuada (para as práticas de leitura) especialmente aos professores das séries iniciais, além de incentivar a percepção da leitura como um investimento precioso que reverbera na construção de imaginários, na capacidade de expressar-se com mais eficiência, na experiência estética da linguagem e no autoconhecimento. Porém, levando em consideração o que tenho observado em relação aos alunos que chegam à universidade, é evidente que a escola não está atuando na formação de leitores (o mesmo vale para a competência escrita). Mas o mais grave é que a escola pode estar corroendo os nossos alunos talentosos e nivelando por baixo os que teriam condições de se destacar.

Precisamos mais do que um fetichismo diante da leitura, mais do que uma encenação piegas sobre o valor histórico e cultural do livro durante a famigerada "Semana do Livro" organizada pela escola. Muitos desses eventos, inclusive, estão completamente esvaziados, haja vista a baixa qualidade do que se oferece aos alunos em termos literários. Projetos como o "autor na escola", via de regra, tornaram-se oportunidades para autores medíocres desovarem sua produção encalhada e lucrarem em cima de inocentes ainda incapazes de separar o joio do trigo. Além disso, são muitos os professores que não têm o hábito da leitura ou que sequer se sentem vexados em admitir que não gostam de ler. Como poderão atuar na formação de novos leitores? 


\section{Dialogia: Diz-se que o Brasil deveria ter mais leitores. Como fazer isso?}

Clóvis Da Rolt: Não creio que a quantidade seja um critério único. Precisamos de um número maior de leitores ou de mais qualidade nos níveis de leitura dos leitores que já temos? Talvez precisemos de ambos, mas isso não será uma tarefa fácil de ser alcançada diante de um país que ainda possui cerca de doze milhões de analfabetos. Se acrescentarmos a este número os analfabetos funcionais e os analfabetos diplomados (sim, o Brasil é um país no qual existe a categoria dos "analfabetos diplomados"), a situação torna-se verdadeiramente caótica.

Sempre acreditei que a leitura, a competência leitora e a formação do leitor são processos difíceis de se enquadrar com precisão. Para aprimorá-los há inúmeras estratégias de fomento, metodologias de ação, formas de incentivo, políticas públicas governamentais, etc. Mas acerca da leitura há também um mistério, algo que costumo associar a uma descoberta, uma revelação, um salto num abismo. Para algumas pessoas este mistério se apresenta, mas não para todas. Mal comparando, é como acreditar no poder e na ação de uma divindade. Chega um ponto em que as catequeses, exegeses e propedêuticas falham: ou você assume o divino ou o descarta. Com a leitura acontece algo semelhante. O mistério não se ensina, se vive. Mais do que teoria, leitura é prática. Quantos estão dispostos a isso?

A leitura é um processo tímido, lento, silencioso. É uma capacidade que vai sendo adquirida e aprimorada mediante a percepção de um tempo interno que varia de leitor para leitor. A leitura exige também a vivência de outras práticas e expressões da cultura e da linguagem que a ela se conectam, como o cinema, a música, o teatro. Isso quer dizer que, através do texto, lemos sempre um mundo em movimento e em conexão com experiências extratextuais.

Acredito que grande parte da formação de um leitor não está necessariamente ligada à escola, ao amparo do Estado, às estratégias de fomento à leitura, à ação de bibliotecas, etc. Tudo isso colabora, mas não é determinante. Ensina-se a técnica, a decodificação de um sistema linguístico, as características de um texto, a estrutura de um romance... Mas não se ensina a emoção, a sedução, a perplexidade, o encantamento e o mistério que fazem parte da leitura. Grande parte de tudo o que envolve a leitura é de natureza estritamente pessoal, é intransferível e intraduzível.

Como país, estamos atrasados em vários aspectos. A leitura é só um deles. Além disso, há pessoas que foram expostas a todos os recursos de incentivo à leitura, estudaram em boas escolas, são vizinhas de uma grande biblioteca, têm tempo disponível, usufruem de 
diferentes experiências culturais... E ainda assim não são leitoras! Se todas as condições favoráveis lhes foram possibilitadas, por que não leem?

\section{Dialogia: Como vê as relações entre Educação e Literatura?}

Clóvis Da Rolt: São relações necessárias, fundamentais e imprescindíveis. Não há educação que possa relegar a literatura a um plano acessório. Uma educação que não contemple a literatura não merece ser qualificada como tal. A literatura constitui um grande arquivo da memória, da expressão simbólica e da sensibilidade humana; é um dos principais meios de entendimento do drama que é a existência. Sem a literatura perdemos um dos meios fundamentais de representação acerca de quem somos nós, além de empobrecermos os sentidos que podemos dar à vida.

Nas tradições antigas, o estudo aprofundado da literatura, da poesia e da linguagem (retórica, gramática, lógica, etc) era condição mínima de civilidade, além de constituir um caminho obrigatório a ser trilhado para uma formação intelectual. Hoje, lamentavelmente, há um movimento de repúdio aos clássicos e às tradições. Falar em "literatura superior" tornou-se ofensivo. Há toda uma militância relativista e desconstrucionista que quer nos fazer acreditar que não existem diferenças entre um poema de Virgílio e a letra de uma canção sertaneja, já que tudo é "expressão" e como tal deve ser entendido. Com isso, estamos legitimando o grotesco e o banal, pois eles também "expressam" alguma coisa. A barbárie cultural mais comezinha tem ocupado um lugar que outrora pertenceu aos gigantes.

Escritores, poetas, artistas, filósofos, bibliófilos e pensadores consagrados disputam hoje espaço com youtubers e "influenciadores digitais", gente que ganha a vida hipnotizando as massas com sofismas, chistes e alguns insights ocasionais. Nesse sentido, penso ser necessário criarmos algumas formas de blindagem, as quais só serão eficazes quando os clássicos voltarem a ser novamente uma presença fundamental frente aos processos de formação e educação. 


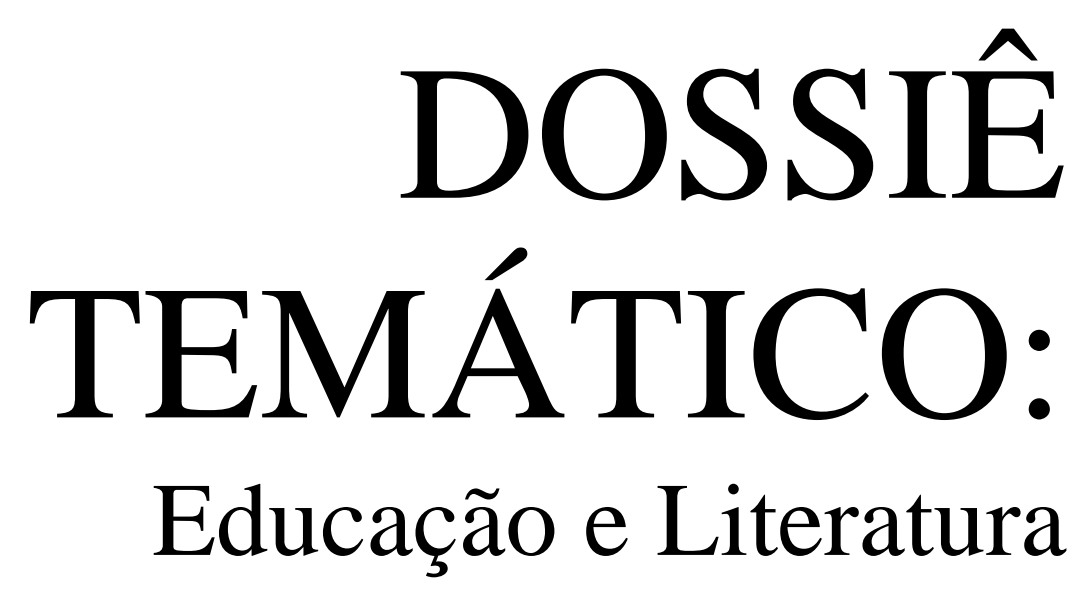

/ THEMATIC DOSSIER:

Education and Literature 


\title{
Drummond e o engajamento literário
}

\author{
Drummond and the literary engagement
}

\author{
Cristiano Perius \\ Doutor em Filosofia. Professor do departamento de Filosofia da Universidade Estadual de \\ Maringá. \\ Maringá - PR - Brasil \\ cristianoperius@hotmail.com
}

\begin{abstract}
RESUMO: Este ensaio examina o tema do engajamento social do artista na obra poética de Carlos Drummond de Andrade, adotando, como critério de análise, as imagens produzidas a partir da atividade do olhar. Ligada ao corpo e a sua dimensão sensível, as metáforas do olhar constituem uma distância intencional apta a estabelecer uma relação de responsabilidade e de compromisso entre o eu lírico e o mundo. Para discutir o alcance desse compromisso, comparamos as teorias do engajamento literário de Jean-Paul Sartre e de M. Merleau-Ponty. Enquanto M. Merleau-Ponty defende uma forma de engajamento perceptivo e apenas indiretamente comprometido com a realidade social, Jean-Paul Sartre, ao contrário, compreende a atividade literária a partir da categoria da ação, que mobiliza o engajamento explícito e correlacionado ao político. A poesia de Drummond, confrontada com esta dupla compreensão do engajamento, satisfaz os dois conceitos.

PALAVRAS-CHAVE: Literatura. Responsabilidade Social. Drummond. Merleau-Ponty. Sartre.
\end{abstract}

ABSTRACT: This essay examines the theme of the social engagement of the artist in the poetic work of Carlos Drummond de Andrade, adopting, as a criterion of analysis, the images produced from the activity of the look. Attached to the body and its sensitive dimension, the metaphors constitute an intentional distance to establish a relationship of responsibility and commitment between the lyrical and the world. To discuss the scope of that commitment, we compared the theories of literary engagement of Jean-Paul Sartre and Maurice Merleau-Ponty. While Merleau-Ponty defends a form of engagement perceptive and only indirectly committed to social reality, Sartre, to the opposite, understands the literary activity starting from the category of the action, that mobilizes the explicit engagement, correlated to the politician. The poetry of Drummond, when responding to this dual understanding of engagement, satisfies both concepts.

KEY-WORDS: Literature. Social Responsibility. Drumond. Merleau-Ponty. Sartre.

Este estudo analisa o tema do engajamento sob a perspectiva das imagens do olhar. A razão desta escolha é natural à experiência de Drummond, que realiza uma poesia corporal e irônica que associa o "olho" (sentido da visão, olhar, óculos) e a "boca" (sorriso, fala). Como observaremos mais à frente, a metáfora dos olhos em seu universo semântico não é um dispositivo meramente estético na atividade poética. Ligada ao corpo e a sua natureza afetiva, o olhar incorpora a dimensão social e política que se aproxima, em determinados momentos, ao conceito de obra de arte engajada e à responsabilidade social do artista. 
Para o exame deste tema importante, que é a responsabilidade poética, adotaremos o seguinte encaminhamento metodológico: de um lado [linha 1], examinaremos a descrição, por assim dizer, "neutra" do mundo, sem parti pris moral ou ético explícito, de outro [linha 2], o engajamento literário em sua forma explícita.

Iniciemos pela "linha 1":

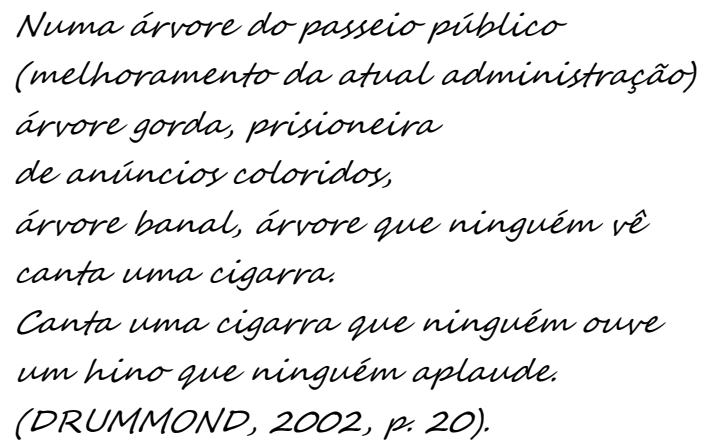

O movimento dos sentidos sobre o mundo, onde o poeta vê/ouve uma cigarra, é efeito do escritor situado como ser-no-mundo (cf. no mesmo poema: "O poeta fecha-se no quarto./ O poeta está melancólico.”). O fenômeno da expressão é o resultado da paisagem visual sobre a percepção aguda dos acontecimentos. A subjetividade do poeta traz à superfície um sentido oculto, não manifesto até o momento. A qualidade do sensível não é ser apenas visual, mas acompanhada pelos outros sentidos:

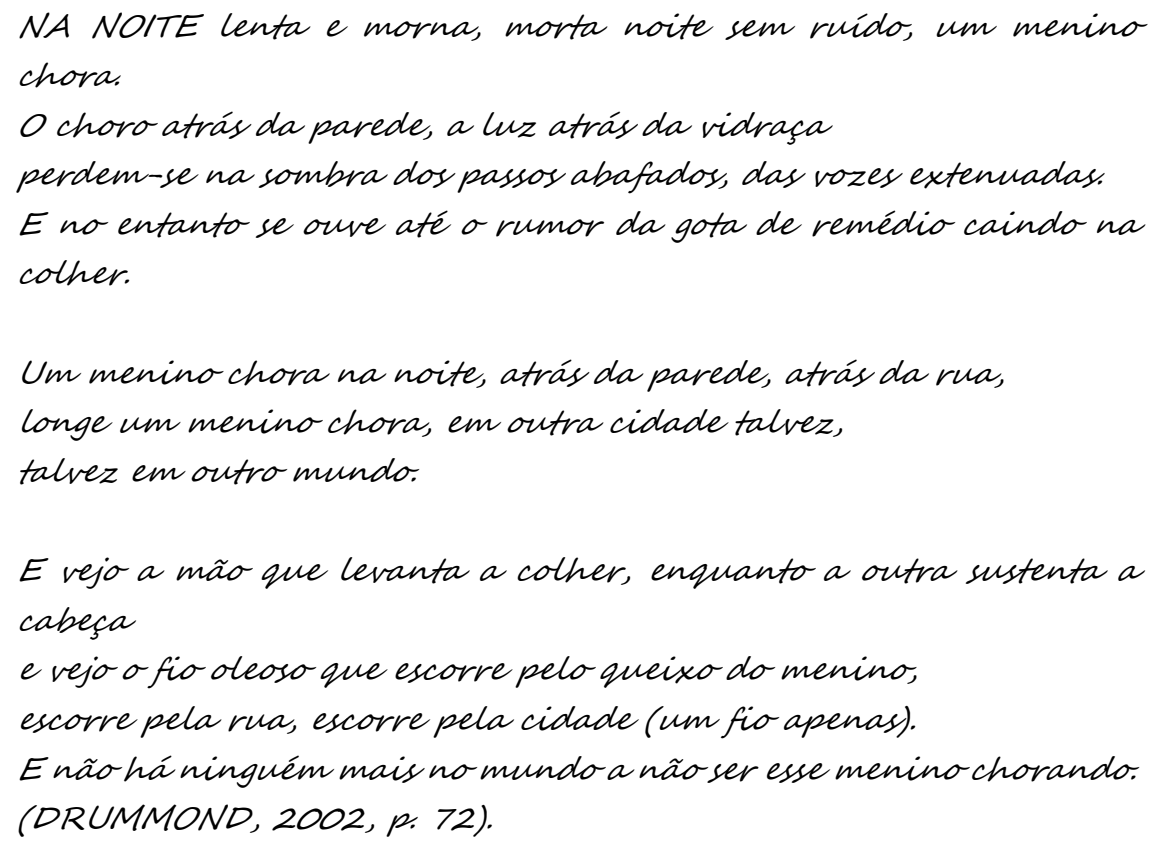

O poema "Menino Chorando da Noite" apresenta a descrição fiel de um fato ordinário que, apesar disso, soa perfeitamente inusitado. Da possível doença do menino ao desespero da 
mãe, a encenação dos versos é dramática. A descrição não trata de uma situação particular, mas, universal: "atrás da parede, atrás da rua,/ longe um menino chora, em outra cidade talvez,/ talvez. em outro mundo." Aqui ou adiante, não importa, o menino chora, e esta sorte de indiferença casuística salienta um fato grave de per si. Escutar a gota de remédio tocando a colher, a mão aproximando-se do menino, os sussurros em torno ao corpo ardente, implica a dimensão corporal, sob a forma de fragmento possível, não conceitual, da afecção sensível. Outro poema complementa este estado de comprometimento afetivo:

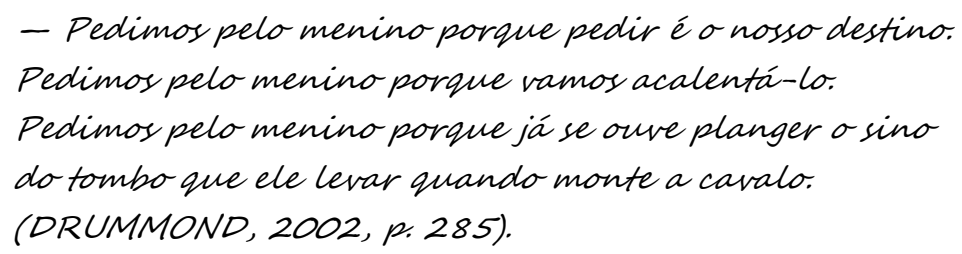

Pedimos pelo menino porque é de nossa natureza o cuidado. A sabedoria do adulto, o desejo de vê-lo crescer sem queda, está em que já viu e aprendeu por experiência, mais do que pelo conhecimento técnico, os perigos da existência. Ora, o conhecimento técnico é desumanizado frente à responsabilidade de quem vê atentamente o mundo ${ }^{i}$. Por certo que o olhar é vago, brinca nas paragens do visível, vê o sapo na lagoa (cf. o poema "Festa no Brejo”), mas, também é responsável. Trata-se de um fenômeno de humanização do olhar que, em alguns momentos, contempla o mundo de forma apática, sem julgamento moral, ético ou político:

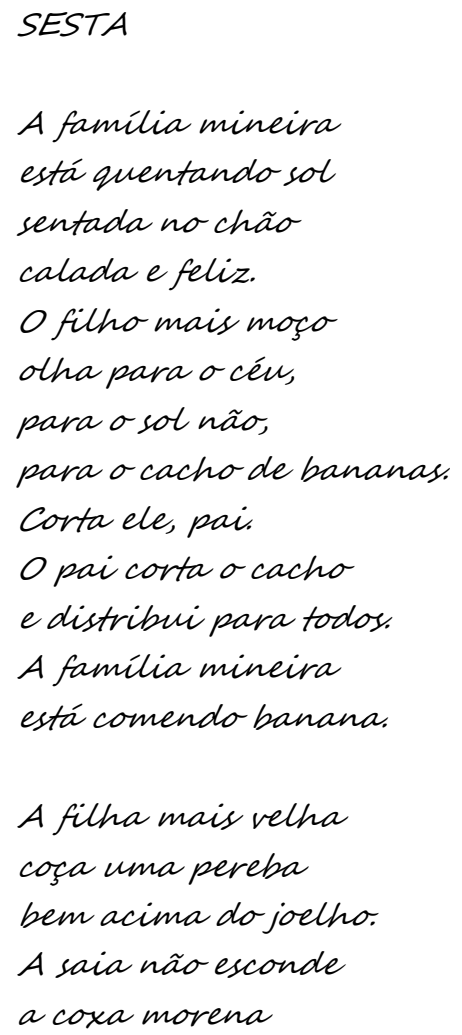




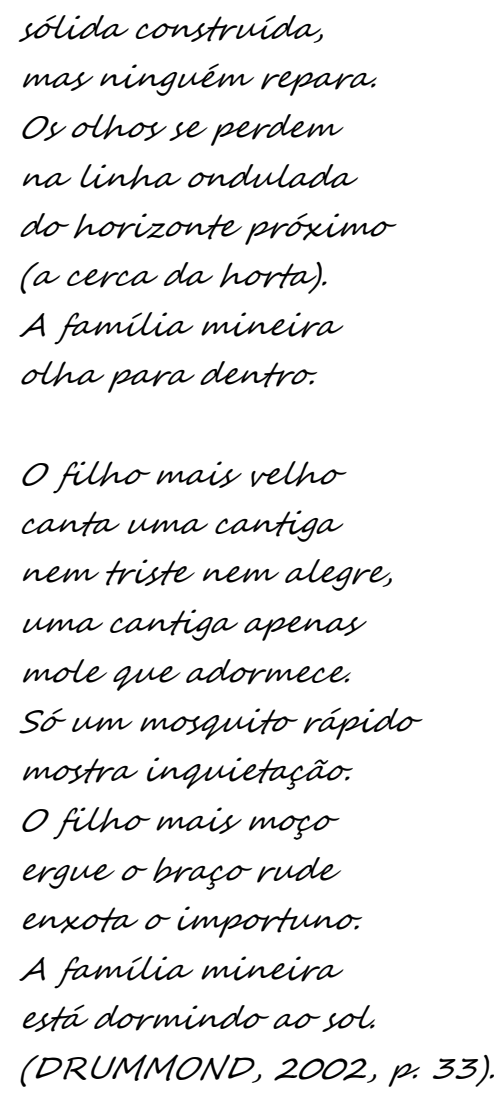

A dinâmica do poema trata de estabelecer um quadro pitoresco. A descrição da família mineira comendo bananas, descansando ao sol, a riqueza em pormenores, a moça coçando a pereba, a cantiga do moço, o mosquito, é tão visual que aproxima o texto da imagem pictórica. “Ut pictura poesis”, pois direciona a comunicação por meio de palavras à descrição pura dos eventos. Outros versos expõem as imagens como o registro visual de estados de coisas:

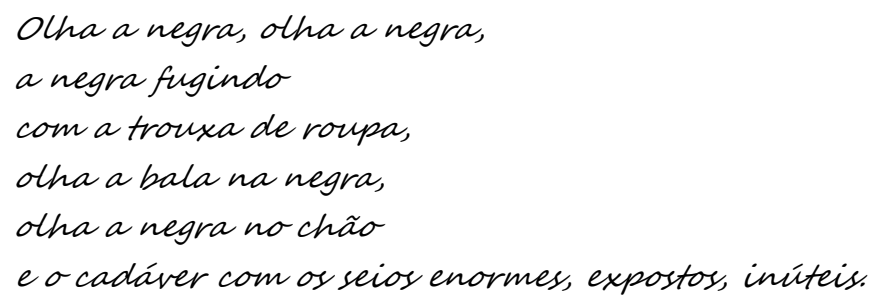

A família mineira, no plano rural e calmo, tanto quanto a exposição do cadáver do morto, no plano urbano e agitado, possuem uma dimensão social eminente. A julgar pelo teor jornalístico da segunda imagem, a notícia do crime suposto, a manchete policial, reforçamlhe o teor crítico, especialmente a marginalidade e o racismo. O que os versos apontam, na contramão do sensacionalismo, a ser recebido pela insensibilidade das massas, é o tratamento impessoal da manchete policial, a indiferença das notícias que exploram o sofrimento das vítimas e não se comprometem. Significa requerer um parâmetro humano de olhar e receber 
a crueldade, em que pesem os mecanismos de divulgação da violência. $\mathrm{O}$ interesse do olhar não é meramente visual e indiferente, não procura motivo de exposição sem critério de investigação consciente. No caso do corpo assassinado, incorpora o reverso da notícia, assim como a simplicidade contemplativa, quase religiosa, da roça mineira, no outro poema. Isso significa que a mera exposição visual das coisas já comporta uma dimensão ética e social, quando ver é testemunhar, isto é, exige a cumplicidade de quem não pode mais negar a realidade em sua emergência característica. Mas isso não é tudo, pois, se é verdade que a dimensão do olhar, mesmo em sua forma neutra e contemplativa [linha 1], já carrega o teor social como forma de testemunha ocular do mundo - da mesma forma como quem saca uma fotografia -, então, será ainda mais eloquente quando passar ao sentimento de responsabilidade em sua forma explícita [linha 2].

Acompanhemos as imagens [linha 2]:

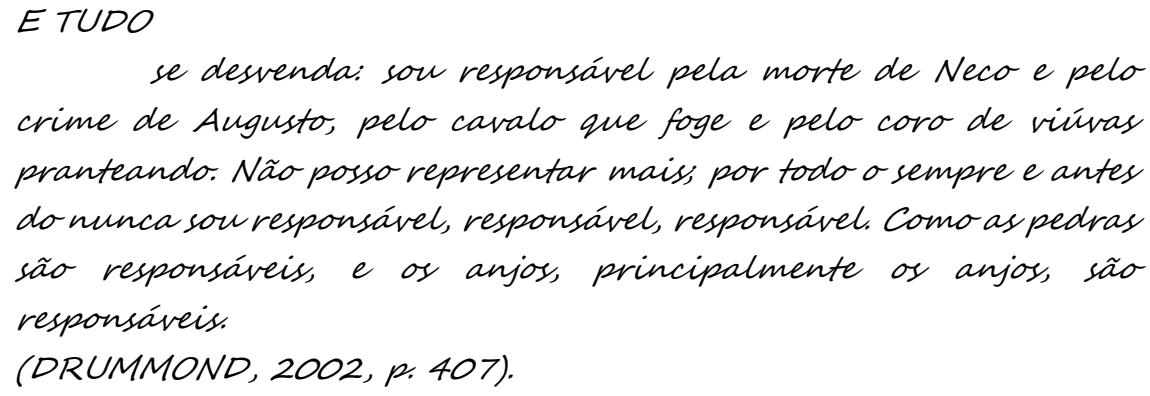

Impossível não evocar a descrição do engajamento literário de “O que é a literatura?”, uma vez que Sartre visa, como se sabe, a responsabilidade do escritor como intelectual atento ao mundo em que vive. Seja através do furor de Émile Zola ao dizer “J'accuse....? em carta aberta ao presidente da república, face aos acontecimentos políticos do seu tempo, seja através da expressão de Dostoievski: "Somos todos culpados de tudo e de todos perante todos, e eu mais do que os outros", a literatura não é neutra, isto é, isenta, como se o acontecimento estético não pudesse ter efeitos éticos e políticos de primeira ordem. O ponto mais alto do engajamento que conduz a consciência poética ao coração dos problemas sociais e políticos é o poema "Nosso Tempo", em especial a sua última estrofe:

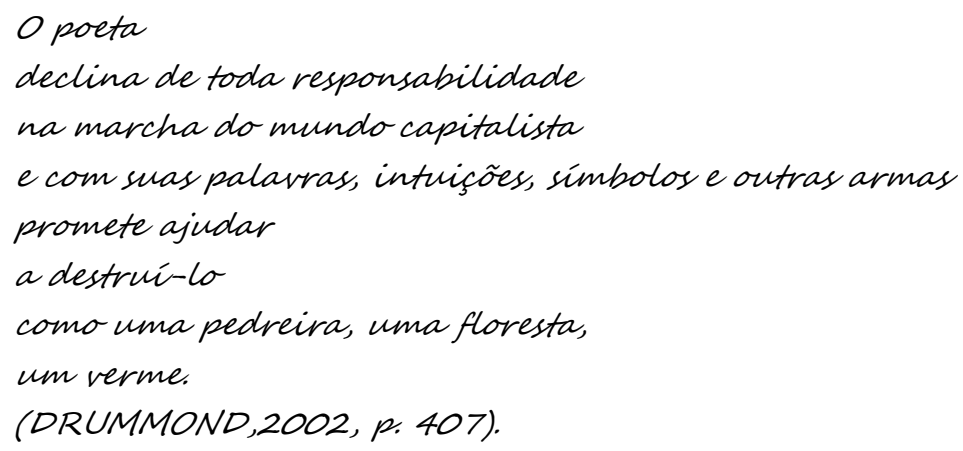


O poeta sabe que "declina", isto é, dá forma a palavras por agrupamento e flexão dos vocábulos do léxico. "Fazendeiro" de versos, sua matéria é o verbo, “apenas arabesco", e, no entanto, ocorre de perceber que este exercício é bem mais do que um jogo de palavras. O poema identifica claramente o lápis ao revólver. Utilizando metáforas da linguagem transitiva, visa agir energicamente contra o estado das coisas. Segundo Jean-Paul Sartre (1948, p. 29): "Ele [o escritor] sabe que as palavras, como diz Brice Parain, são 'pistolas carregadas'. Quando fala, ele atira. Pode calar-se, mas uma vez que decidiu atirar é preciso que o faça como um homem, mirando o alvo, e não como uma criança, ao acaso, fechando os olhos, só pelo prazer de ouvir os estampidos.” A letra do poeta não é mais, como em outras escolas literárias, a defesa de ideais abstratos, românticos ou metafísicos. (Tampouco a fala doce da literatura beletrística, diletante e recreativa, que nem sequer é literatura, se pensamos em campeões de audiência - que vão da auto-ajuda a histórias de alquimia -, e na Academia Brasileira de Letras, de que grandes escritores brasileiros, entre eles, Drummond, não participaram.) É um instrumento de guerra. Toda a máquina poética é então, “com suas palavras, intuiçoes, símbolos e outras armas", um grito de resistência e de combate. (DRUMMOND, 2002, p.125) “Meu nome é tumulto, e escreve-se/ na pedra." Poeta coletivo, não fala por si mesmo, solidário aos que não falam, em particular aos mais desfavorecidos:

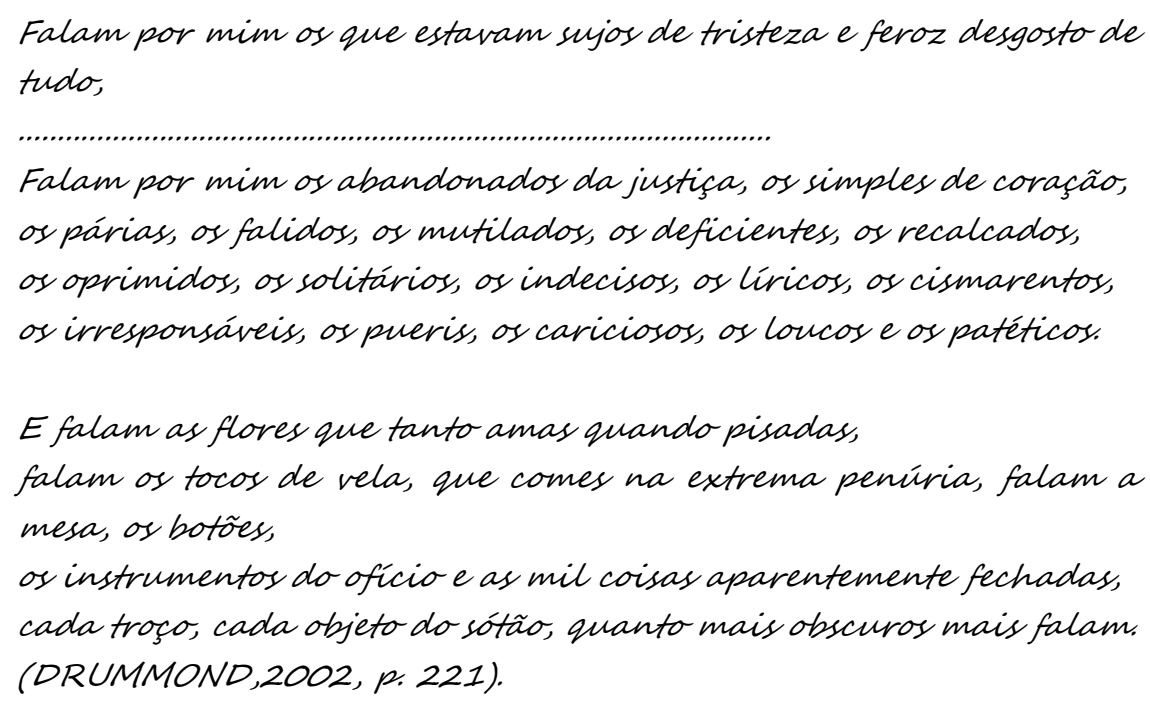

A disposição do poeta é servir de porta-voz aos homens, atingindo de modo eloquente os quatro cantos da Terra: 
Ó conta, velha preta, ó jornalista, poeta, pequeno historiador urbano, ó surdo-mudo, depositário de meus desfalecimentos, abrete e conta, moca presa na memória, velho aleijado, baratas dos arquivos, portas rangentes, solidão e asco,

pessoas e coisas enigmáticas, contai,

capa de poeira dos pianos desmantelados, contai;

velhos selos do imperador, aparelhos de porcelana partidos, contai; ossos na rua, fragmentos de jornal, colchetes no chão da costureira, uto no braço, pombas, cães errantes, animais caçados, contai. Tudo é tão dificil depois que vos calastes...

E muitor de vós nunca se abriram.

(DRUMMOND, 2002, p. 127).

Ataca então a página por todos os lados, preenchendo rapidamente os espaços brancos. $\mathrm{O}$ primeiro excerto acima é do poema "Nosso Tempo", de $\boldsymbol{A}$ Rosa do Povo, que dispõe de um total de 179 linhas e VII partes. "Canto ao Homem do Povo Charle Chaplin", citado em seguida, também de $\boldsymbol{A}$ Rosa do Povo, contém 225 linhas e VI partes. Trata-se do poema mais longo de Drummond. Esta observação é relevante, se considerarmos que a média de tamanho dos poemas de Drummond é muito inferior. A avaliação quantitativa aponta para o sentimento de sucesso a um poeta acostumado a registrar o desequilíbrio provocado pelo imenso trabalho para pouco material verbal. Ora, a razão deste sucesso é o ingrediente ético. Rompendo a barreira solipsista, o poeta atinge de forma exuberante as imagens de convívio, caminhando de mãos dadas com os homens. Em outras palavras, a eticidade é alcançada pelos canais de participação e de humanização da sociedade histórica e concreta. Trata-se de ligar o fenômeno de expressão poética ao ideal de transformação social e política — de que a coletânea de 1945, A Rosa do Povo, é o maior expoente. Que se note, neste sentido, o nítido contraste entre o exercício de uma poesia social participante, cujo genitivo objetivo: “...do povo", já manifestava formalmente, e o tônus hermético e classicista, voltado à cor cinza, de Claro Enigma, publicado em 1951.

Tudo se passa como se o poeta, passado o alvorecer inicial dos primeiros quatro livros - onde se firma como representante do segundo modernismo brasileiro - , abraçasse os ideais socialistas através da poesia participante que é $\boldsymbol{A}$ Rosa do Povo, se decepcionasse, desacreditasse, quase completamente silenciasse, dissolvendo a euforia dos anos de ouro através do Claro Enigma, voltado ao soneto, às sombras do tempo, à bílis negra, às cinzas das tumbas - o columbário —- e, recusando a oferta, seguisse o passo cabisbaixo, lasso, caprichoso. Ora, A Rosa do Povo é de 1945, e reúne os poemas escritos na primeira metade daquela década, período de florescimento do socialismo utópico e dos ideais participantes 
que não sobrevivem a duas guerras mundiais, onde vence a incerteza, o pessimismo próprio do pós-guerra, que coincide com os anos de produção do Claro Enigma.

Todavia, se é verdade que a perspectiva ética e social, após a coletânea de 1945, se arrefece, nem por isso deixa de lado a atividade de olhar o mundo, editado, agora [no Claro Enigma, e nas coletâneas imediatamente sucessivas], pela disposição de uma nova experiência estética, marcada pelo pessimismo, ceticismo, hermetismo, orfismo, entre outras qualidades inerentes. Isso significa que Drummond não abandona o engajamento, mas o transforma a partir de um novo dispositivo crítico. Lembremo-nos de José Guilherme Merquior, que define o tônus do Claro Enigma como "pessimismo crítico - ainda mais crítico do que pessimista" (MERQUIOR, 1975, p. 190). Tal perspectiva de leitura é contrária à tripartição clássica: poesia irônica, social e metafísica, em primeiro lugar porque o engajamento do olhar, tanto quanto o teor irônico e metafísico, não é exclusivo a um período, em segundo, porque o tema da responsabilidade poética não acaba, mas, modifica-se. Muito pelo contrário: toda a poética de Drummond está comprometida com o engajamento do olhar, mesmo quando não encontra solução viável. A perspectiva do Claro Enigma, então, e das coletâneas imediatamente sucessivas, longe de significar o embotamento, explora outra forma de pensar o ser-no-mundo (e o ser-para-outro), mesmo que sob a intenção de fugir do tempo presente e editar o tempo mítico.

O que define a responsabilidade poética não é apenas o compromisso explícito com a luta política e a reforma de classes, mas a dialética gradual e ambivalente do engajamento direto e indireto - denominados linha 2 e linha 1, respectivamente. Se não fosse assim, isto é, se apenas a temática diretamente social fosse portadora de valor, perder-se-ia grande parte do alcance deste vasto tema que é "Literatura e Sociedade" (sublinhe-se: “ $\underline{e}$ "), isto é, a rede complexa e infinita de intercâmbios entre a universalidade e o eu lírico, o eu e o mundo. De fato, há uma gama de interfaces, de relações multilaterais e interdisciplinares no teor artístico, que, embora autônomo, interage com as ciências (questões cognitivas), com as normas éticas e políticas (questões morais e cívicas), com os problemas insolúveis da existência (questões metafísicas). Segue disso a conclusão de que o engajamento é melhor compreendido quando acompanhamos o registro poético da imagem do mundo no eu lírico, isto é, o "sentimento do mundo". A presença corporal do poeta "sério, simples e forte", segundo o "Poema de Sete Faces", indica o trabalho de imaginação poética através da atividade de olhar o mundo sensibilizado com o que vê. Só assim compreende-se a razão das "pupilas gastas na inspeção contínua" (do poema "A Máquina do mundo") e as "retinas fatigadas" (do poema "No meio do caminho"). Sinal de que a atividade do olhar não é só passiva, isto é, não atua apenas como 
testemunha ocular do mundo [linha 1], pelo contrário, passagens há em que o peso das imagens deixa os olhos liquidados [linha 2]: “eu vi; já não quero ver” (DRUMMOND, 2002, p. 141); "Meus olhos são pequenos para ver// — mas veem, pasmam, baixam deslumbrados." (DRUMMOND, 2002, p. 205). Ora, o título do poema dos dois últimos versos é "Visão 1944", escrito explicitamente sobre a II Guerra Mundial. De forma que o mundo histórico e concreto, onde o homem vive e relaciona-se socialmente, longe de ser descrito de forma fantasiosa ou idílica, é uma fonte permanente das imagens.

Enfim, a responsabilidade poética pode ser medida enquanto olhar de cumplicidade com o meio contemplado. O olhar que participa, direta ou indiretamente, da realidade concreta, não quer dizer assentimento, mas a face combativa do poeta, recusando a disposição habitual das coisas. Este ato de recusa é resultado da decisão de não permanecer indiferente em face às imagens. Mais ainda, indica a pretensão de praticar uma poesia corrosiva, revolucionária:

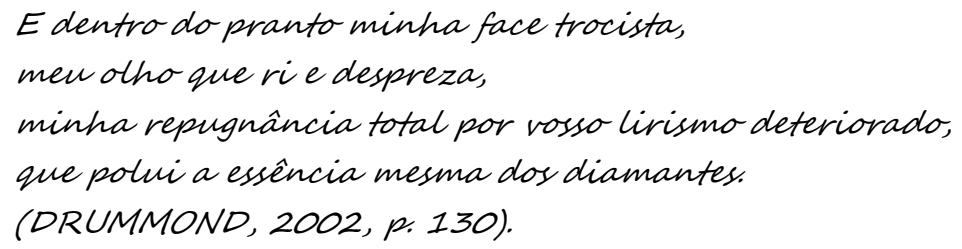

Os versos relacionam o riso e o choro que, mesmo no quarteto inicial do poeta (Alguma poesia, Brejo das almas, José e Sentimento do Mundo), onde o chiste e a piada são mais frequentes, são apresentados segundo um trabalho de identificação entre o cômico e o trágico. Vejamos dois exemplos. 1. "Os desiludidos do amor/ estão desfechando tiros no peito./ [...] enquanto as amadas dançarão um samba/ bravo, violento, sobre a tumba deles." (DRUMMOND, 2002, p. 59); 2. "E o amor sempre nessa toada:/ briga perdoa perdoa briga.// Mas, se não fosse ele, também/ que graça que a vida tinha?// Mariquita, dá cá o pito,/ no teu pito está o infinito." (DRUMMOND, 2002, p. 8) Como podemos ver nestas passagens, a situação trágica é elevada ao patético da exposição satírica. Pensemos nos poemas "José" e "Quadrilha". De forma que o olhar poético elege o essencial da vida, deixando, onde passa, o abraço solidário da visita [inha 2], ou apenas, com o melhor humor possível, a descrição das coisas em sua forma dura [linha 1].

O que justifica esta leitura do engajamento a partir de duas linhas é a compreensão de que a literatura comunica-se com o plano social de forma oblíqua e indireta - apesar de, em determinados momentos, desempenhar a função de porta-bandeira à ação concreta. Prova desta possibilidade é Réjean Ducharme (1996, p. 57), em L'avalée des Avalés, que 
diz: "Tudo que espero de um livro é que me diga que há mais vida do que a que espero encontrar, que me inspire a força e a coragem e que me diga quando é hora de agir." Tratase de opor, como seria necessário, as teorias do engajamento de Sartre e de Merleau-Ponty. Nas Cartas de uma Ruptura, Merleau-Ponty interroga-se para saber qual é a melhor relação entre o filósofo e a cidade, mencionando a figura de Sócrates. Sobre a relação correta entre filosofia e política - relação extensiva à literatura, pois que se trata da função dos intelectuais, sejam eles quem for, pensadores, escritores ou poetas -, ao contrário de Sartre, cogita a separação entre filosofia e política, chegando a dizer que "antes de mais nada, uma coisa é certa: houve uma mania política entre os filósofos que não rendeu nem em boa política nem em boa filosofia.” (MERLEAU-PONTY, 1960, p. 10). A razão para a má filosofia está na exigência de que o intelectual desempenhe uma função eminentemente social e política (exigência esta que, supostamente, também vale para a intensão de suas palavras). Ora, segundo Merleau-Ponty, a teoria da ação imediata corrompe o núcleo sadio do engajamento, pois o filósofo, o poeta, nem sempre sabe (como) agir. De forma que em lugar de uma “filosofia da ação pura",iii aplicada a Sartre, está uma "filosofia da ambigüidade", aplicada a Merleau-Ponty, para quem a subjetividade do escritor é tributária de uma colcha prévia, endereçada ao sensível.

\section{Dois engajamentos: Sartre (lógos humano) e Merleau-Ponty (lógos estético)}

Vejamos claramente a diferença entre os autores. Para Sartre, escrever é sinônimo de agir, pois "se Deus não existisse, tudo seria permitido". A frase é de Dostoievski, citada por Sarte imediatamente após a afirmação de que "estamos agora num plano em que há somente homens" (SARTRE, 1973, p.24.). Ou seja, não há nenhum tipo de fundamento transcendente ou salvador, nada tem, a priori, valor, a não ser o que fazemos por meio de nossas escolhas. Portanto, os valores são absolutamente mundanos, isto é, dependem exclusivamente do engajamento e responsabilidade dos homens, uns para com os outros. Daí porque todas as ações nos comprometem. Não agir é ainda uma forma de ação. Estamos sempre engajados, mesmo quando o ignoramos. Até mesmo no romance $\boldsymbol{A}$ Náusea lê-se a famosa frase de Roquentin: "O menor gesto me engaja". Sartre reconhece que, de forma semelhante a Kant, o homem é um fim em si mesmo. Age de forma livre e autônoma, ou seja, ao menos no plano ontológico, é responsável pelo que faz e não tem desculpas. "Tal é o homem que nós concebemos. Homem total. Totalmente engajado e totalmente livre." (SARTRE, 1949, p. 28). Ser homem significa, tal como aos mitos gregos (de Prometeu à 
caixa de Pandora), que nada somos por natureza e, por isso mesmo, estamos abertos a todas as possibilidades. $\mathrm{O}$ homem não tem nenhuma essência, mas se faz livremente, criando valores e conquistando a dignidade. O valor humano é paradoxal, pois surge da contradição entre não ser nada prévio ao que faz por meio de ações concretas e, por isso mesmo, subordinado a elas.

Em que medida esta descrição do fenômeno humano não é válida para MerleauPonty? Na medida em que na fenomenologia de Merleau-Ponty não aparece como categoria fundamental o ser-em-si-para-si, mas o sensível. Não é a consciência nadificadora o conceito ontológico fundamental, isto é, a intencionalidade radical que faz do homem um ser regido pela falta de ser, mas o ser de indivisão, o ser bruto ou selvagem, isto é, a imbricação [empiétement] ambígua e incompleta (visível e invisível, manifesta e oculta, iluminadora e ocultadora) contida no sensível. Assim, da consciência nadificadora (Sartre) ao sensível (Merleau-Ponty), a diferença é clara, pois passamos do lógos do mundo humano ao lógos do mundo estético, isto é, da rivalidade absoluta entre ser-em-si e ser-para-si, segundo Sartre, pois jamais teremos a paz das coisas, a um horizonte prévio ao homem, que pertence à natureza. Se o lógos humano e o lógos estético diferem, é porque a expressão da natureza primordial não contém nenhuma ação, mas, esquemas perceptivos embrionários e prémundanos, que necessitam o devir da expressão, isto é, o tempo de "acontecer" no mundo. Para Sartre, a questão do engajamento tem por fundo a transitividade do signo prosaico, a partir do projeto original de um ser que, ao decidir escrever, provoca a liberdade do leitor. Para Merleau-Ponty, no entanto, não é a categoria da ação o efeito imediato da linguagem literária, mas a vocação expressiva da percepção. O recurso à ação é revogado em nome da percepção incoativa e infinita que, mais do que designar estados de coisas mundanos, remodela e reconfigura estes estados. $O$ engajamento literário, então, modifica-se sensivelmente, porque a fala originária não é linguageira, mundana, mas, prenunciativa e iniciadora do que vai ser.

Nas cartas trocadas entre Sartre e Merleau-Ponty, por ocasião da ruptura entre os filósofos, encontram-se elementos que discutem a forma do engajamento. Da parte de Sartre, lemos a acusação de que Merleau-Ponty retira-se da política com a finalidade louvável, do ponto de vista pragmático, de escrever um texto filosófico, ou seja, a censura de Sartre sobre o colega não recai sobre a crítica a seu posicionamento político em si, mas sobre o lugar de onde parte esta crítica. Nas palavras de Sartre (apud MERLEAU-PONTY, 2000, p.135, grifo do autor): 
Quem discute a atitude daqueles que permanecem sobre o terreno objetivo da política e que tentam, bem e mal, escolher entre motivos objetivamente válidos, torna-se também criticável de uma apreciação objetiva. Mas tu não és aquele que diz: farei melhor se eu me abster. Tu és aquele que diz aos outros: é preciso se abster. Foi duro ler, na revista Express, o relatório de uma conferência que fizeste aos estudantes onde me taxaste publicamente como errado.

Trocando em miúdos, o que Sartre diz é o seguinte: "Posiciona-te como quiseres e critica-me, pois toda posição política é criticável. O que não aceito é ser criticado por alguém em cima do muro, afirmando que qualquer tomada de posição é um equívoco." Qual é a resposta de Merleau-Ponty a Sartre? Muito semelhante à afirmação de Signos segundo a qual "houve uma mania política entre os filósofos, que não rendeu nem boa política, nem boa filosofia", Merleau-Ponty responde que a boa filosofia (e, portanto, a boa política) é pura e simplesmente "ambígua", isto é, não carrega em si mesma o dispositivo da ação imediata sobre os acontecimentos, mas guarda recuo ou distanciamento em relação aos mesmos. Esta é a razão pela qual reclama a neutralidade editorial da Revista Les Temps Modernes, que, “em vez de tomar posições apressadas, deve fazer estudos de conjunto, visar o leitor pela cabeça e não pelo coração, pois a ação do escritor consiste em fazer o vai e vem entre o acontecimento e a linha geral, não em afrontar (no imaginário) cada acontecimento como se fosse decisivo, único e irreparável.” (MERLEAU-PONTY, 2000, p.148) Está clara então a objeção que Merleau-Ponty endereça a Sartre: o engajamento, se for possível, não é evidente, nem imediato. Todavia, a posição de Merleau-Ponty não é a torre de marfim, a inatividade. Lógos estético não quer dizer desengajamento. Pelo contrário, o que ele defende é o engajamento à distância e indireto, em oposição ao que chamou de "engajamento continuado - em sentido cartesiano", isto é, o engajamento cuja ação é tão urgente a ponto de estar fadado a repetir-se a cada situação ou fato. Nas palavras de Merleau-Ponty (2000, p.148, grifo do autor):

\footnotetext{
Meu método é mais próximo da política que teu método de engajamento continuado (no sentido cartesiano). Ora, por isso mesmo, ele é mais filosófico, pois a distância que ele põe entre o acontecimento e o julgamento desfaz a armadilha do acontecimento e deixa ver claramente o sentido. Eu não tinha nenhuma necessidade de separar a filosofia do mundo para permanecer filósofo - e nunca o fiz. Seria necessário que ouvisses com mais atenção a lição de abertura [O Elogio da Filosofia], que dizes ter compreendido. Tratei de Sócrates para mostrar que o filósofo não é um fazedor de livros e que não sai jamais do mundo.
} 
Para Merleau-Ponty, o exemplo de Sócrates é inequívoco. A política não é um acessório para Sócrates - este que foi condenado à cicuta, sob o pretexto de corromper a juventude. Sartre, no entanto, acusa Merleau-Ponty de misturar política e filosofia. Nas palavras de Sartre (apud MERLEAU-PONTY, 2000, p.138): "Um membro do MRP pode criticar minha apreciação da guerra da Indochina, um socialista pode criticar minha concepção do PC, mas ninguém tem o direito de fazê-lo em nome da épochè fenomenológica". Ora, o que dá à política este ar tão suscetível e inseguro, infenso a acordo durável? Mais uma vez, é exemplar a observação de Merleau-Ponty no Prefácio a Signos: "Em filosofia, o caminho pode ser difícil, mas temos certeza de que cada passo torna possível os outros. Em política, temos a impressão acabrunhante de que tudo deve ser sempre refeito.” (MERLEAU-PONTY, 1960, p.10). Em outras palavras, muito aquém do (belo) universal filosófico, constituído por relações necessárias entre conceitos, está o mundo (sujo) da política, construído sobre relações pragmáticas, estratégicas e passageiras. O que Merleau-Ponty visa, portanto, com o nome de Sócrates neste momento é dizer a Sartre que, de fato, não podemos separar as coisas: ninguém deixa a cidade para ser filósofo. É o mesmo ser filósofo (escrever livros) e ser cidadão (se meter na política).

Diante deste debate entre Sartre e Merleau-Ponty nas Cartas de uma Ruptura, podemos perguntar o seguinte: em que medida esta conclusão, válida para o engajamento do filósofo, também vale para o engajamento da literatura? Ora, a identidade entre o filósofo e o cidadão, legítima para a conexão entre filosofia e política, também ocorre com o escritor, pois o poeta, o romancista, também é cidadão, ou seja, não está fora do mundo, mesmo quando pensa a metafísica. Qual é então a verdadeira ligação entre o artista e a cidade? Para responder esta pergunta, importa perceber o deslocamento de Merleau-Ponty em relação a Sartre. O elo entre o artista e a cidade é explícito, segundo Sartre, porém o mesmo não acontece, segundo Merleau-Ponty. Senão, vejamos:

O estudo que vamos ler dá uma descrição evidente do meio pré-humano, abaixo do tempo e da vida, que é o da arte e da literatura. Se o autor os desconecta da preocupação de exprimir a experiência humana, é porque a arte, segundo ele, coloca-se antes do mundo verdadeiro, e que o artista não é ainda um homem. (MERLEAU-PONTY, 1997, p. 122).

A afirmação de Merleau-Ponty coloca em cheque o "engajamento continuado" sartriano, uma vez que coloca a atividade artística em estado de vanguarda, isto é, aquém ou além do mundo instituído. Em outra afirmação da mesma página, Merleau-Ponty acrescenta: 
Mesmo se reintegramos a literatura à atividade significante do homem, se a tomamos inteiramente como fala e questão do autor com o seu público, há de fato uma solidão do escritor, há, na expressão literária e artística, um questionamento sobre si mesmo e um humor sonhador que fazem do escritor um mau partidário e, seguidas vezes, como se diz, um homem sem caráter.

Notemos, nesta frase, três níveis de defasagem entre o belo (valor estético) e o correto (valor moral), três estados gradativos de aproximação, in crescendum, entre a boa arte e a má política, uma vez que admite a legitimidade de uma obra de arte produzida pelo artista: 1) solitário; 2) sem partido; 3) sem caráter. Em outras palavras, Merleau-Ponty está pensando a possibilidade da alienação do artista em face ao mundo, pois trabalha só, sem amigos, sem reconhecimento, mais ainda, seu exercício implica a possibilidade de um posicionamento equivocado do ponto de vista empírico, revelando a distância entre o espaço aberto por uma obra de alcance visionário e conceitual, de um lado, e a miopia ou a fragilidade psicológica de quem a produziu, de outro. Devemos concluir disso que o engajamento não é possível, dado os obstáculos efetivos que Merleau-Ponty nos apresenta? Nada disso. O elo intrínseco ou o nó górdio entre os domínios ético e estético está de pé. Trata-se do engajamento como problema filosófico. Este problema filosófico (o est-ético), não está fora do horizonte de ambos os filósofos, embora, como se sabe, não estão de acordo quanto a forma deste engajamento.

\section{Conclusão}

Depois destas rápidas considerações sobre o engajamento literário de Merleau-Ponty e de Sartre, voltemos ao ponto de partida. Onde está o Drummond neste debate? A resposta é a seguinte: o engajamento perceptivo, passivo e à distância, de que fala Merleau-Ponty, é muito claro à luz das imagens da poética de Drummond na linha 1. Trata-se de engajamento do olhar, cujas imagens são primordialmente visuais e "neutras", isto é, efeitos da intencionalidade produzida a partir da subjetividade de quem vê o mundo à distância sem parti pris ético ou político em sentido explícito, isto é, sem emitir juízo. Esta forma de engajamento visual não suprime, contudo, a outra forma, mais sanguínea, declarada e explícita [linha 2].

Prova de que a poesia de Drummond, a julgar pelo debate desse tema, agrada gregos e troianos. 


\section{Referências}

CAEYMAEX, F. La dialectique entre Sartre et Merleau-Ponty. In : Dialectique, littérature : avec des esquisses inédites de la «Critique de la raison dialectique ». [Revue Études Sartriennes, n¹0.] Bruxelles : Ed. Ousia, 2005.

DRUMMOND DE ANDRADE, Carlos. Poesia completa. Rio de Janeiro: Ed. Nova Aguilar, 2002.

DUCHARME, Réjean. L'avalée des avalés. Paris: Gallimard, 1966.

MERLEAU-PONTY, Maurice. Parcours. Paris: Verdier, 1997. . Parcours deux. Paris: Verdier, 2000.

. Signes. Paris: Gallimard, 1960.

MERQUIOR, José Guilherme. Verso universo em Drummond. Rio de Janeiro: J. Olympio, 1975.

SARTRE, Jean Paul. O existencialismo é um bumanismo. São Paulo: Editora Abril Cultural, 1973.

Qu'est-ce que la littérature? Paris: Gallimard, 1948.

Situations II. Paris: Gallimard, 1949.

\section{NOTAS:}

'Que o leitor perdoe a inescapável remissão de uma passagem do poema acima ("Os Bens e o Sangue") associado à tragédia, ocorrida no dia 05/11/2015, envolvendo a mineradora Samarco e as vítimas de Mariana: "E virá a companhia inglesa e por sua vez comprará tudol e por sua vez perderá tudo e tudo volverá a nadal e secado o ouro escorrerá ferro, e secos morros de ferrol taparão o vale sinistro onde não mais haverá privilégios". ((DRUMMOND, 2002, p.285)

ii "Ut pictura poiseis" é uma expressão latina, atribuída a Horácio, fundada sobre a fraternidade entre as artes. Embora só tenha adquirido força de teoria estética no Renascimento, os estudos de comparação entre as artes plásticas e a literatura são bem mais antigos. Note-se, neste sentido, a formulação de Plutarco, segundo a qual a pintura é uma poesia muda e a poesia é uma pintura falante. O recurso valorativo/comparativo entre as artes, no entanto, entrou em decadência após o Renascimento, tendo como opositor mais conhecido o texto Laocoon, publicado em 1766, de autoria de Lessing. Embora o lema desta escola não seja o ideário estético de Drummond, não deixa de ser interessante observar, neste poema, a aproximação entre poesia e pintura.

iii Expressão de Florence Caymex. Cf. CAEYMAEX, F. La dialectique entre Sartre et Merleau-Ponty. In: Revue Études Sartriennes, n.10. Bruxelles : Ed. Ousia, 2005, p. 132. 
recebido em 10 set. 2018 / aprovado em 19 nov. 2018

Para referenciar este texto:

PERIUS, C. Drummond e o engajamento literário. Dialogia, São Paulo, n. 30, p. 19-34, set. /dez. 2018. Disponível em: <https://doi.org/10.5585/Dialogia.n30.10481> 


\title{
As poéticas de cuidado com o meio ambiente na literatura infantil e juvenil brasileira
}

\author{
The poetics of environmental care in brazilian children's and young literature
}

\begin{abstract}
Eliane Santana Dias Debus
Doutora em Linguística e Letras pela Pontifícia Universidade Católica do Rio Grande do Sul. Professora da Universidade Federal de Santa Catarina. Florianópolis - SC - Brasil. elianedebus@,hotmail.com

José Carlos dos Santos Debus Doutor em Educação pela Universidade Federal de Santa Catarina. Professor colaborador da Unidade de Educação de Santa Catarina. Florianópolis - SC - Brasil. zecadebus@gmail.com
\end{abstract}

\begin{abstract}
Resumo: $O$ artigo busca problematizar a temática do meio ambiente na literatura para infância e juventude, em particular naquelas narrativas que apresentam e representam a relação das personagens com os recursos hídricos, levando em conta o contexto da discussão da preservação natural como primícia, recaindo sobre títulos que têm as águas como força potencializadora: Os rios morrem de sede (1976), de Wander Piroli, e Água de anil (2014), de Nilma Lacerda. Procuramos evidenciar nestas narrativas uma poética de cuidado com o meio ambiente, para isso nos apoiamos nos estudos da Ecoliteracia (RAMOS; RAMOS, 2013) e os estudos da Ecocrítica (CAPRA, 2008; GARRARD, 2006). Constatamos na análise a recorrência do cuidado de forma diversa, porque diferentes são os momentos históricos da escrita e o contexto da produção afeta o resultado para esse leitor que já não é mais o mesmo. No entanto, não impossibilita a experiência leitora com as questões ambientais.

Palavras-chave: Literatura. Temática do meio ambiente. Poética de cuidado.
\end{abstract}

Abstract: The article seeks to problematize the environmental theme in the literature for childhood and youth, in particular in those narratives that present and represent the relationship of characters with water resources, taking into account the context of the discussion of natural preservation as a first step, falling on titles that have the waters as a potentiating force: The rivers die of thirst (1976), Wander Piroli, and Agua de anil (2014), by Nilma Lacerda. We try to show in these narratives a poetic of care with the environment, for this we support the studies of Ecoliteracia (RAMOS, RAMOS, 2013) and Ecocritical studies (CAPRA, 2008, GARRARD, 2006). We find in the analysis the recurrence of care in a different way, because different are the historical moments of writing and the context of production affects the result for this reader who is no longer the same. However, it does not preclude the reader experience with environmental issues.

Keywords: Literature. Theme of the environment. Poetic of care.

O presente artigo busca problematizar a temática do meio ambiente na literatura infantil e juvenil brasileira, em particular naquelas narrativas que apresentam e representam a relação das personagens com os recursos hídricos. Levando em conta o contexto da discussão da preservação natural como primícias, nosso foco recai sobre títulos de autores 
brasileiros de tempos distintos, são eles Narizinho Arrebitado, de Monteiro Lobato, publicado pela primeira vez em 1920; Os rios morrem de sede, de Wander Piroli, publicado na década de 1970 e Agua de anil, de Nilma Lacerda, publicado na segunda década do século XXI, procurando evidenciar nessas narrativas, cada qual a seu modo, uma poética de cuidado com o meio ambiente.

O momento histórico da escrita das narrativas em questão, por certo, corrobora para uma visão distinta da natureza, em particular a temática da água, bem como nos modos comunicativos desses com o público leitor criança. Uma visão encantatória da representação da água, alongada por um período de poucas indústrias poluentes e a não escassez de recursos hídricos, na década de 1920, a uma visão de denúncia na década de 1970, momento dos resultados dos primeiros impactos de destruição da natureza no Brasil e outra, no início do terceiro milênio, que agudiza a relação das mãos humanas e as relações de poder. Assim, as palavras que emergem dessa escrita se circunscrevem as águas doces de três rios de travessias diversas.

A leitura dessas narrativas se articula as leituras de referenciais teóricos sobre e para a educação literária, para a Ecoliteracia, em particular nos estudos de Ana Margarida Ramos e Rui Ramos (2013) articulados ao projeto "Meio ambiente e ecoliteracia na novíssima Literatura Infantil e Juvenil", bem como uma aproximação com os estudos da Ecocrítica (CAPRA, 2008) que buscam estudar a relação entre literatura e meio ambiente.

\section{Dos dizeres da natureza - para além e com o literário}

Água que nasce na fonte serena do mundo

E que abre o profundo grotão

Água que faz inocente riacho e deságua

$\mathrm{Na}$ corrente do ribeirão

Águas escuras dos rios

Que levam a fertilidade ao sertão.

(Guilherme Arantes - Planeta Água)

A música "Planeta Água”, concorrente do Festival MPB Shell em 1981 - integra o álbum "O amanhã" pela Elektra -, que compõe a discografia do compositor e cantor brasileiro Guilherme Arantes, anuncia de forma sensível, e poderíamos dizer também romântica e idealizada, a importância da água e a relação e dependência dos seres vivos com esse bem tão precioso. Música símbolo de um período em que as discussões no Brasil sobre o meio ambiente se faziam ainda novidadeiras. Da década de 1980 a esta segunda década do 
século XXI, transformações no modo de ser e pensar a natureza se fizeram e o debate sobre o tema se agudizou.

O Brasil, por certo, é privilegiado no que diz respeito aos mananciais de águas que habitam seu solo. Em suas terras, de dimensões continentais, se abriga uma grande parte do Sistema Aquífero Guarani, manancial de água doce subterrânea, que tem fronteira com os países da América latina Paraguai, Uruguai e Argentina, sendo que no Brasil o aquífero está distribuído no solo de oito estados. No entanto, tal fato não inviabilizou a crise de água na maior cidade do país, São Paulo, por exemplo, provocando um racionamento sem precedentes na história nos anos de 2013 e, principalmente, 2014. Evidenciando o quão somos dependentes da água e que não existem projetos em longo prazo que evitem tal crise, já que estava anunciada há alguns anos.

Tal situação demonstrou o descuido das mãos humanas, seja no aspecto privado, seja no aspecto público. O uso indiscriminado da água no dia a dia das pessoas comuns e pequenas empresas (lavação de calçadas, prédios, entre outros), como no dia a dia de pessoas públicas, responsáveis por políticas de cuidado (ausência de um cuidado em longo prazo; falta de previsão e provisão) promoveu uma crise exigindo uma mobilização por partes de diferentes instâncias.

Da mesma forma, o desastre ambiental sem precedentes no distrito de Bento Rodrigues, localizado no município de Mariana (Minas Gerais/Brasil) provocado pelo rompimento de duas barragens de rejeitos de minério de ferro da empresa Samarco, em 05 de novembro e 2015, potencializa as discussões sobre os cuidados e preservação com o meio ambiente, a partir do cenário de desolação que tomou conta da região e se estendeu por outros estados; rios e córregos foram engolidos por lama; a vida marinha extinta: peixes soterrados; solo esterilizado sem possibilidade de vida, tal resultado demonstra como a natureza é frágil impotente diante da ação humana.

O discurso de defesa e preservação da natureza, bem como de políticas de sustentabilidade ecoa por diferentes redes e se anuncia como imprescindível neste século XXI em que a natureza grita. Uma nova consciência e comportamento dos cidadãos crianças, jovens, homens e mulheres - gentes de todas as etnias, gêneros e classes sociais - é exigido nestes tempos marcados pelo consumo descartável e aligeirado dos bens de consumo.

Seria possível promover práticas de cuidado e proteção do meio ambiente por meio do texto literário sem cair em discursos moralizantes e esvaziados? A literatura para crianças e jovens tematiza em suas narrativas a problemática ambiental? Quais as relações 
estabelecidas entre o tempo histórico (passado/presente/futuro) e os discursos para infância nos livros literários?

No artigo "Os primórdios da relação entre literatura para a infância e ambiente em Portugal” (2017), Ângela Balça e Fernando Azevedo traçam um panorama da temática ambiental na literatura para infância portuguesa, demarcando a década de 1970 como marco crucial da sua inserção, a partir de dois acontecimentos. O primeiro de nível mundial diz respeito à Conferência das Nações Unidas sobre o Meio Ambiente Humano (1972) e outro local que se refere a Revolução de 25 de Abril de 1974. Os estudiosos analisam títulos considerados emblemáticos, como Valéria e a Vida (1976) e Voa, pássaro, voa (1978), de Sidônio Muralha, Beatriz e o Plátano (1976), de Ilse Losa e Sílvia Montarroyos e Histórias do bicbinho qualquer (1980), de Silvia Montarroyos.

No artigo "Ecoliteracia e literatura para a infância: quando a relação com o ambiente toma conta dos livros", Ana Margarida Ramos e Rui Ramos (2013) analisam um conjunto de títulos portugueses para infância a partir da década de 1960, com ênfase nos contemporaneíssimos, elencando a representação da natureza nesses títulos e a sua importância para um respeito para com a natureza. Levando em conta a semântica da palavra ecoliteracia - eco/oiko (casa) e literacia (conhecimento/competência) os autores destacam que "o indivíduo possuidor de ecoliteracia, ou literacia ecológica, será aquele que detém competências e conhecimentos acerca da sua 'casa', aqui tomada como o ecossistema planetário". (RAMOS; RAMOS, 2013, p. 17); esse indivíduo teria uma relação sustentável com os elementos com os quais; seria responsável por suas atitudes e ações.

Segundo Ramos e Ramos (2013, p. 17):

A ecoliteracia é a capacidade de os cidadãos desenvolverem um tipo de pensamento favorável à desconstrução do paradigma antropocêntrico que caracteriza as sociedades ocidentais e as suas consequências mais diretas, nomeadamente a concessão do homem como legítimo explorador do meio natural em seu proveito e a da natureza como uma inesgotável fonte de bens ao dispor de todas as necessidades e desejos humanos (o providencialismo). A essa desconstrução corresponde a edificação de uma concessão ecocêntrica, segundo a qual o homem se encontra integrado num sistema biológico complexo, cujo equilíbrio deve constituir uma aspiração individual e coletiva.

Capra (2008) remete a uma "alfabetização ecológica" que deveria ser parte importante de todas as esferas, entre elas a educação em todos os seus níveis de ensino, não ficando circunscrita a uma disciplina, mas presente poderíamos dizer, enraizada ao currículo escolar como um todo. Ainda, segundo o autor, as artes, e nesse caso específico de nosso texto, a narrativa literária pode ser "um instrumento poderoso para ensinar o pensamento 
sistêmico." (CAPRA, 2008, p. 24-5), em que as relações estão imbricadas fio a fio, pois fazemos parte do mesmo tecido que constitui a biosfera.

Nem tão perto, nem tão longe podemos trazer a ecocrítica para esse diálogo ao refletirmos sobre a representação do meio ambiente na literatura, pois a ela coube o estudo relacional dessas duas áreas. O termo ecocriticism cunhado na década de 1970, por meio de algumas coletâneas produzidas na década de 1980, é um campo de estudo que se efetiva na década de 1990, quando é criada a disciplina Literatura e Meio Ambiente na Universidade de Nevada, Reno, Estados Unidos da América. (PINTO; MAGALHÃES, 2013).

Garrard (2006) em seus estudos descreve três tropos, figuras de como a natureza é representada, consubstanciados na relação homem e natureza: a pastoral, o mundo natural e o apocalíptico. Nos dois primeiros a relação estésica com a natureza, numa compreensão das sensações e da relação com o meio de forma aprazível faz parte das representações; no último numa relação apocalíptica, por vezes desacreditada pelas versões proféticas de aniquilação da natureza, é uma das mais recorrentes pelos ambientalistas contemporâneos. Não buscaremos obrigatoriamente ler os títulos propostos pela lente dos tropos, mas eles nos ajudam a situar uma representação de natureza, cada qual nos seu tempo histórico.

Sob a mirada dos estudiosos aqui elencados adentramos a análise dos três títulos anunciados, trazendo para o debate da literatura para infância a conexão entre o contexto da escrita: a realidade literária (ficcional) e o contexto da leitura: a realidade vivida (de carne e osso) e como elas se imbricam.

\section{Que águas deságuam na literatura brasileira para infância? Três livros, três momentos}

Não temos a pretensão de fazer um mapeamento quantitativo dos títulos brasileiros para infância que tematizam a água, até porque seria difícil quantificá-los e qualificá-los no que se refere aos seus fins, de mera representação ambiental para a movimentação das personagens ao protagonismo da cena. Deteremos-nos, como já explicitado, em três livros específicos que foram publicados em três momentos distantes temporalmente no contexto brasileiro: Reinações de Narizinho (1931), de Monteiro Lobato, circunscrito ao universo dos primeiros livros infantis produzidos no Brasil; Os rios morrem de sede (1976), de Wander Piroli, pertencente à fase do "boom" da literatura para infância e juventude e Água de Anil (2014), 
de Nilma Lacerda publicado nesta segunda década do século XXI, ou seja, quase 80 anos o separam do primeiro livro em análise.

A temática da natureza sempre esteve presente nas narrativas infantis, a representação da fauna e flora, tem sido um dos grandes objetos dessa produção. Embora tenhamos autores que cantaram de forma ufanista as belezas da pátria, como os versos de Olavo Bilac no início do século XX, e a partir de uma visão nacionalista como as narrativas de Monteiro Lobato na década de 1920, sabe-se que a temática se sobressai a partir do final da década de 1970, trazendo para o cenário da escrita para infância e juventude a denúncia de depredação da natureza pela mão humana à narrativas denuncias de uma crise ecológica do início do século XXI que demarcam a devastação da natureza, como o recente Um dia, um rio (2016), de Leo Cunha, com ilustrações de André Neves, que tematiza a morte do Rio Doce/Mariana - de forma sensível e encharcada de poeticidade. Na correnteza barrenta do rio em suspensão as palavras navegam denunciando, mas ao mesmo tempo anunciando possibilidade de redenção. As ilustrações de André Neves, por certo, impactam o leitor desmobilizando-o do seu olhar cotidiano ao focar nos pequenos restos/objetos cobertos de barro/lama. Os dizeres dessa narrativa instauram outra maneira de trazer as discussões ambientais sobre os lugares que habitamos e que nos habitam, de forma singular e distinta do cotidiano, inaugurando um olhar alargado sobre o tema.

Narrativas de ontem e de hoje que nos cabe seguir o percurso.

\section{Primeiro Momento - navegando por águas límpidas}

O escritor Monteiro Lobato publicou seus livros para crianças entre o período de 1921 e 1945, a par de outros títulos, como Histórias Diversas e textos esparsos, publicados pós-morte. Sua literatura trouxe à cena uma representação de criança irriquieta, perguntadeira, criativa, em contraponto com as crianças reais que não possuíam espaço para colocarem em exercício suas traquinagens, cercadas que estavam pelo mundo dos grandes.

Em 1931 Lobato reúne em um único exemplar denominado Reinações de Narižinho 11 livros que obedeciam a características específicas que inseriam no mesmo plano a realidade e o imaginário, sem fins mais específicos do que o da própria "alegria" do ato de ler, prazer a ser descoberto pelo leitor nas linhas e entrelinhas de histórias que partiam do microuniverso do Sítio do Picapau Amarelo e, muitas vezes, se estendiam por espaços temporais e geográficos ora determinados, ora indeterminados. Exemplo disso está no livro Pena de papagaio (1930), em que, como que entrando numa máquina imaginária do tempo, as 
personagens são transportadas ao mundo das fábulas a dialogar com os fabulistas Esopo e La Fontaine.

Duas são as narrativas desse livro que nos servem de mote à escrita: "Narizinho Arrebitado" e "Reino das Águas Claras". A representação da água no microuniverso do Sítio do Picapau Amarelo, criado por Lobato é construída em dois planos: um do "real" da vida cotidiana das personagens, representado pelo ribeirão que corta o Sítio de Dona Benta e outra "paradisíaca" e fantasticamente ficcional no plano onírico das crianças em viagem por espaços fantásticos, como o Reino das Águas Claras.

Corre pelos fundos do pomar do Sítio um ribeirão de águas "apressadinhas e mexeriqueiras", e é em sua beirada que a menina Narizinho e a boneca Emília "sentam na raiz dum velho ingazeiro para dar farelo de pão aos lambaris.” (LOBATO, 1993, p.7). No plano do sono sonhado, a menina e a boneca visitam o Reino das Águas Claras, espaço paralelo ao Ribeirão em que habitam serem marinhos de toda espécie, inclusive o Príncipe escamado, pretendente da menina:

Que lindos lugares ela viu! Florestas de coral, bosques de esponjas vivas, campos de águas das formas mais estranhas. Conchas de todos os jeitos e cores. Polvos, enguias, ouriços - milhares de criaturas marinhas tão estranhas que até apreciam mentira do barão de Munchause. (LOBATO, 1993, p.12).

A poética lobatiana é a da exaltação da natureza potencializadora de uma beleza impar, uma visão nacionalista e positiva da natureza. Uma natureza sem a interferência da mão humana. Os personagens lobatianos usufruem dela em seu estado bruto, sem o conflito entre uso e abuso.

Podemos aqui retomar a ideia de "tropos mundo natural" (GARRAD, 2006) de um Reino fantástico intocado pelas mãos humanas, preservado do olhar adulto, privilégio de usufruto da infância, pois somente à Narizinho e Emília é permitido o encontro num Reino de Águas tão límpidas. Por outro lado, o ribeirão, localizado no Sítio "real”, é lugar de repouso e remanso, portal para o fantástico.

\section{Segundo momento: condições adversas de navegação}

A produção de Wander Piroli surge na década de 1970, dentro de um momento específico da literatura infantil brasileira, em que os temas até então silenciados como a 
representação realista da infância, a separação dos pais, morte, a preocupação ecológica, entre outros se tornam possibilidades de enredo. O menino e o pinto do menino e Os rios morrem de sede, ambos do autor e publicados na Coleção do Pinto, da Editora Comunicação, de Belo Horizonte. Segundo Lajolo e Zilberman (1987, p. 126) "parece ter cabido a ela a consolidação (mesmo que ao preço de um certo escândalo) de uma literatura infantil comprometida com a representação realista e às vezes violenta da vida social brasileira".

$\mathrm{Na}$ narrativa Os rios morrem de sede, o pai, ontem filho, leva agora o seu menino, como o seu pai o fazia, para pescar, isso fica evidenciado quando diz a sua esposa: "- Você sabe, nega: eu sou o Bumba, Bumba sou eu. Como papai era então eu, e agora eu sou ele." (PIROLI, 2015, p. 16). Revestido de uma memória nostálgica o homem realiza os preparativos que antecedem a pescaria, envolto em minúcias e calmaria: preparar o alforje, as varas de pescar, a garrafa de café, tudo organizado para a saída na mansidão da manhã, mal o dia clarear. Alertado pela esposa de que o rio não seria mais o rio da sua infância, ele alerta:

- Eu achava que vocês não deviam ir lá - observou a mulher.

- Tenho que ir.

- Deixa então o Bumba.

- Eu esperei ele crescer, nega. Ele precisa ir. Ele vai comigo como se eu estivesse indo com papai e nada tivesse mudado.

- Você sabe que tudo está mudado. Você mesmo disse que até o rio está acabando. (PIROLI, 2015, p. 17).

No percurso - das ruas silenciosas de Belo Horizonte ao trajeto da Estação de Trem - a viagem que busca unir os fios do passado vai sendo costurada pelo diálogo da rememoração do pai que traz ao filho o rio da sua infância. Ao chegar próximo do rio, encontram um velho canoeiro que vive não mais dos peixes mas da venda de areia, pois o rio se transformará em certa parte num imenso areal.

O rio não é mais o mesmo. O rio largo, profundo e limpo de outrora era agora raso, encardido e de margens despidas.

Desceram a plataforma e foram caminhando em silêncio ao lado da linha do trem, até encontrar uma estradinha que devia levar ao rio. [...] Através da neblina, notou que a margem do outro lado do rio também estava pelada, e o rio, quase no osso, se estendia lento, a água suja, marrom. Não havia sequer um pequeno arbusto para dependurar o embornal. (PIROLI, 2014, p. 31).

A poética de Piroli é de denúncia, denúncia de destruição ambiental: “Os rios morrem de sede". No entanto, a personagem adulta não se compromete e não se coloca como 
culpado da destruição. A culpa é dos outros, "Os filhos da puta". Frase forte que é repetida pelo filho, menino de sete anos que imita o pai repetindo "Fedaputa". Mais brutal do que a expressão e o gesto do menino que acaba cuspindo no velho rio.

Aqui poderíamos fazer uma analogia com o Tropo pastoral (GARRARD, 2006) contrastando o passado de natureza exuberante em que o rio era "vivo" e o presente em que o rio está “morto". A denúncia da destruição ecológica, embora seja o mote, ela não é realizada num tom profético de aniquilação, mas de resignação.

\section{Terceiro momento - Água de Anil, de Nilma Lacerda}

Nilma Lacerda e a literatura do século XXI - Texto não linear, composto de fragmentos de diferentes discursos (rol-lista; dramático, memorialístico); vozes que se cruzam e entrecruzam e deságuam nas mesmas águas, águas de anil. Os diferentes discursos na narrativa lhe dão um ritmo célere. Há uma urgência narrativa como as águas que correm e deságuam ...

Rosalvo, filho da lavadeira Dinalva, aprende muito cedo a ler o rol da lista das roupas lavadas por sua mãe. O menino estuda e se torna doutor deputado e a temática de preservação do meio ambiente, plataforma de sua eleição, é logo esquecida quando entra o jogo de forças do poder. Consciente da distância entre seus ideais de mocidade e seus atos, a personagem retoma a infância na procura do anil. $\mathrm{O}$ anil usado para limpar a roupa é o recurso usado pelo menino, já adulto, para renascer em outro lugar:

Já é madrugada. Cheiro de infância na casa, barulho de rio aqui dentro. Estou cansado, e é difícil dormir. O olhar de taturana arde em minha memória, revira camadas antigas, eus dentro de mim. Caminho em branco, sustos da noite, mágoas, lágrimas, manchas, respiração difícil.

Minha vida tão ligada ao rol de roupa. Minha infância a se admirar da trouxa de roupa suja virando alva e cheirosa.

Fico em casa nessa manhã. Preciso buscar esse olhar (LACERDA, 2014, p. 67).

A poética de Lacerda denuncia os discursos contraditórios do cuidado com as questões ambientais e os jogos de poder no plano político. Escrito de forma sensível a autora anuncia e denuncia o sentimento de culpabilidade da personagem que se purifica, não para se eximir, mas para retornar a luta. Uma luta que é politica e economicamente ganha pelo lobby dos grandes produtores rurais. Rosalvo vai à lona sem lutar. Todas as conquistas que idealizou na juventude para a preservação da vida junto aos rios vão aos poucos se esvaindo 
no emaranhado das concepções políticas dominantes. "Mais de uma vez planejei fazer umas viagens pelo estado, seguir o curso dos rios principais, ouvir o povo, ribeirinhos, pescador, mas Brasília é um sugadouro.” (LACERDA, 2014, p. 39). Rosalvo até se animava para a luta e ensaiava alguns embates. "Mas meus protestos se afogaram em água pouca. Engoli a seco [...].” (LACERDA, 2014, p. 41). Os rios, suas nascentes e as matas ciliares ficavam completamente desprotegidos diante da ampliação do cultivo da soja no cerrado e Rosalvo é calado diante de argumentos socialmente estabelecidos nos discursos majoritários e também se entrega a estes discursos: "A soja tem um impacto enorme no produto interno bruto. Cerrado não alimenta ninguém. Nem faz justiça social.” (LACERDA, 2014, p. 54). Sua derrota e a possibilidade de reação também são incorporadas pelos discursos dominantes e ele se entrega: "o fato é que na juventude somos levados por impulsos, fantasias; a maturidade pede prudência e moderação" (LACERDA, 2014, p. 54).

A luta em defesa das questões ambientais é assumida por outro narrador, o "garoto do blog”. Que começa questionando: “O verdes tão perdendo a guerra?” (LACERDA, 2014, p. 45). Há uma reflexão sobre o meio ambiente desde o mundo antigo, na Grécia. Com a natureza se modificando pela própria ação da natureza. Temos os fatos da natureza, mas também temos os fatos da ação do homem. Aqui o destaque da narrativa vai para "dialética do conforto": "queremos um planeta saudável, mas buscamos luxos e comodidades que exigem enorme dispêndio de recursos naturais. Consumimos mais do que necessitamos, desperdiçamos sem remorso, a reciclagem é tímida [...].” (LACERDA, 2014, p. 45).

A narrativa de Água de Anil faz uma analogia com os quintais que já tivemos em nossas casas com pés de abacate, carambola, acerola, entre outras e que, por conta do consumismo e do desejo de morar perto do trabalho, os entregamos para a especulação imobiliária. Segundo o narrador, acabamos com o pé de abacate e começamos a fazer leis para proteger os abacateiros. Por outro lado, “os pés de abacate impendem o desenvolvimento de uma patente de abacate sintético que vai facilitar a vida das pessoas, então a lei dá uma volta para desproteger o que protegia." (LACERDA, 2014, p. 49). Aqui entra o discurso político do contrassenso que dissimula e permite que "elegemos deputados verdes, senadores verdes, que encontram todas as justificativas para o voto contrário ao discurso que dizem defender.” (LACERDA, 2014, p. 49). Deste modo, “a soja avança sobre as veredas, lambendo o cerrado como língua seca. Em lugar da diversidade, uma única espécie que rende $\$ \$ \$ \$ \$ \$$ nas exportações” (LACERDA, 2014, p. 49). São essas incongruências que engolem o político Rosalvo. "Filho da mãe de blog [...]. Tudo baderneiro [...].” (LACERDA, 2014, p. 63). 
As angústias de Rosalvo o levam de volta a sua meninice a procura de anil para purificar sua vida. "Ainda me lembro? Encher o balde de água, dissolver o anil, embeber o pano, torcer para tirar o excesso, enrolar o pano na vassoura, passar no chão, depois nas paredes, nos móveis. [...] Deixar as janelas abertas para secar naturalmente" (LACERDA, 2014, p. 67).

O tom profético de uma natureza aniquilada - não pelo indivíduo, mas pelo coletivo; não pelo privado, mas pelo público - se faz audível em Água de anil.

\section{Na imprecisão da vida, navegar é preciso}

Levando em conta o contexto da discussão da preservação natural como primícia, nosso foco recaiu sobre os títulos que têm as águas como força potencializadora, entre eles Reinações de Narizinho (1920), de Monteiro Lobato; Os rios morrem de sede (1976), de Wander Piroli e Água de anil (2014), de Nilma Lacerda, procurando evidenciar nestas narrativas uma poética de cuidado com o meio ambiente. Constatamos que a recorrência do cuidado se dá de forma diversa, porque diferentes são os momentos históricos da escrita e o contexto da produção afeta o resultado para esse leitor que já não é mais o mesmo. No entanto, não impossibilita a experiência leitora de modos distintos de ver e viver as questões ambientais.

Com(o) (con)viver na natureza? Ontem e hoje, nas narrativas, somos convidados a reflexionar as distintas posturas de habitar, mas, por certo, o habitar "não é uma estado transitório; ao contrário, implica a imbricação a longo prazo dos seres humanos numa paisagem de memória, ancestralidade e morte, de ritual, vida e trabalho." (GARRARD, 2006, p. 154).

Os dizeres dessas narrativas instauram outra maneira de trazer as discussões ambientais sobre os lugares que habitamos e que nos habitam, de forma singular e distinta do cotidiano, inauguram um olhar alargado sobre o tema, auxiliando na construção de um pensamento ecológico. Podemos por certo crer em uma educação ecológica por meio de uma educação literária.

Somos náufragos a deriva, a espera do outro que nos transporte a um lugar seguro para aportar. No entanto, seria importante pensar que na imprecisão da vida, navegar é preciso. 


\section{Referências}

BALÇA, Angela; AZEVEDO, Fernando. Os primórdios da relação entre literatura para a infância e ambiente em Portugal. Textura, v. 19 n. 39, jan./abr.2017.

CAPRA, F. Educação. In: TRIGUEIRO, A. (Coord.). Meio ambiente no século 21: 21 especialistas falam da questão ambiental nas suas áreas de conhecimento. 5 ed. Campinas, SP: Autores Associados, 2008. p. 19-33.

CUNHA, Leo. Um dia, um rio. Ilustração de André Neves. São Paulo: Pulo do Gato, 2016.

DISCOGRAFIA PLANETA ÁGUA. Festival MPB Shell, 1981. Álbum O Amanhã (pela Elektra).

GARRARD, Greg. Ecocrítica. Trad. Vera Ribeiro. Brasília: Editora UNB, 2006.

LACERDA, Nilma. Água de anil. Il. Kammal João. São Paulo: DSOP, 2014.

LAJOLO, Marisa; ZILBERMAN, Regina. Literatura infantil brasileira: histórias e histórias. São Paulo: Ática, 1987.

LOBATO, Monteiro. Reinaçães de Nariz̧inho. Ilustração de Manuel Victor Filho. São Paulo: Brasiliense, 1993.

PINTO, Francisco Neto Pereira Pinto; MAGALHÃES, Hilda Gomes Dutra. Contribuição da ecocrítica ao ensino de literatura. Litterata, v.3, n. 1, 2013. Disponível em: <http://periodicos.uesc.br/index.php/litterata/article/view/808/832>. Acesso em: 21 nov. 2018.

PIROLI, Wander. Os rios morrem de sede. Ilustração de Lelis. São Paulo: Cosac Naify, 2015.

RAMOS, Rui; RAMOS, Ana Margarida. Ecoliteracia e literatura para a infância: quando a relação com o ambiente toma conta dos livros. Solta Palavra, 19, Porto, abr. 2013. Disponível em:

$<$ http://repositorium.sdum.uminho.pt/bitstream/1822/23877/1/Ramos $\% 2$ c $\% 20$ A. $\% 20$ M. $\% 20 \mathrm{e} \% 20$ Ramos $\% 2 c \% 20 R . . p d f>$. Acesso em: 21 nov. 2018.

recebido em 03 set. 2018 / aprovado em 19 nov. 2018

Para referenciar este texto:

DEBUS, E. S. D.; DEBUS, J. C. S. As poéticas de cuidado com o meio ambiente na literatura infantil e juvenil brasileira. Dialogia, São Paulo, n. 30, p. 35-46, set. /dez. 2018. Disponível em: <https://doi.org/10.5585/Dialogia.n30.10420> 


\title{
Entre margens: Guimarães Rosa na sala de aula
}

\author{
Between the margins: Guimarães Rosa in the classroom
}

\begin{abstract}
Júlio de Souza Vale Neto
Doutor em Teoria e História Literária pela Universidade Estadual de Campinas. Professor do Curso de Letras da Universidade Federal de São Paulo. São Paulo - SP - Brasil juliovalleunifesp@gmail.com

Lara Silva Perussi Bertão Mestranda em letras pela Universidade Federal de São Paulo. São Paulo - SP - Brasil lara.perussi@hotmail.com

Nayra Mikie Dias Kikuchi Mestranda em letras pela Universidade Federal de São Paulo. São Paulo - SP - Brasil nayra03@hotmail.com
\end{abstract}

Resumo: Este artigo propõe uma abordagem didática para "A Terceira Margem do Rio", um dos mais famosos contos de Guimarães Rosa. Neste contexto, sugerem-se alguns aspectos para a sua abordagem no Ensino Médio, bem como algumas possíveis atividades de avaliação. Baseado em diferentes fontes teóricas - que combinam documentos oficiais como os PCN (Parâmetros Curriculares Nacionais) e as OCEM (Orientações Curriculares para o Ensino Médio), alguns estudiosos do ensino de literatura como Vincent Jouve e diferentes trabalhos críticos sobre "A Terceira Margem do Rio" - , o texto pretende destacar a importância da literatura na escola, na qual o professor desempenha um papel específico e mesmo crucial.

Palavras-chave: Literatura. Ensino. Conto. Guimarães Rosa.

\begin{abstract}
This paper shows a didactical approach of "A Terceira Margem do Rio", one of the most famous short stories written by Guimarães Rosa. In this context, we suggest some aspects to approach this text at the High School level, including possible evaluation activities. Based on different theoretical sources - which combines official documents as PCN (National Curriculum Parameters) and OCEM (Curriculum Orientations of High Schoo), some authors who think about literary teaching as Vincent Jouve and different critical works about "A Terceira Margem do Rio" -, we intend to highlight the importance of literature in the school, where teacher develops a specific role, even crucial.
\end{abstract}

Keywords: Literature. Teaching. Short Story. Guimarães Rosa. 


\section{Considerações Iniciais}

Considerando a leitura enquanto uma atividade complexa e multifacetada, que pode ser entendida como um processo de cinco dimensões - neurofisiológica, cognitiva, afetiva, argumentativa e simbólica (JOUVE, 2002) ${ }^{1}$-, este artigo tem por objetivo, ocupando-se da relação entre leitura e educação, apresentar uma proposta de aula de Literatura Brasileira concebida para o último ano do Ensino Médio, a partir da qual se vislumbram alternativas metodológicas para a valorização da leitura literária no espaço escolar.

Salienta-se que o ensino de Literatura nas escolas é regulado por diversos documentos oficiais, como os Parâmetros Curriculares Nacionais $(\mathrm{PCN})^{2}$ e as Orientações Curriculares para o Ensino Médio (OCEM). Em se tratando das Orientações, concebe-se o texto literário de modo mais complexo do que mais um modo discursivo dentre vários, sendo assim diferenciado não só pela elaboração linguística que prevê, mas também pela transgressão decorrente do exercício de liberdade proporcionado aos leitores, donde se conclui que a função da arte e, por isso, da literatura, dentro e fora das instituições de ensino constitui-se

[...] como meio de educação da sensibilidade; como meio de atingir um conhecimento tão importante quanto o científico - embora se faça por outros caminhos; como meio de pôr em questão (fazendo-se crítica, pois) o que parece ser ocorrência/decorrência natural; como meio de transcender o simplesmente dado, mediante o gozo da liberdade que só a fruição estética permite; como meio de acesso a um conhecimento que objetivamente não se pode mensurar [...]. (BRASIL, 2006, p. 52-3).

Dessa forma, elegeu-se o conto "A terceira margem do rio", publicado originalmente em 1962, no livro Primeiras Estórias, por acreditar-se que tal escrito roseano compreende a pluralidade significativa inerente às grandes obras literárias, uma vez que, suscitando desde o seu título a ambientação do insólito, o texto propicia “[...] um agenciamento metafórico, plural, criativo, provocativo do mundo [...]" (DALVI, 2013, p. 84). Submetido a uma mediação pertinente, crê-se que o conto atraia o interesse do leitor, seja porque problematiza questões contemporâneas próprias do meio social a que pertence, seja porque, distanciandose e aproximando-se de tais questões, dentro de suas camadas de "insolidez", constitui-se como “[...] 'álgebra mágica’ que por mais indeterminada é mais exata.” (BRAGANÇA, 2000, p. 662). Pretende-se, então, que os alunos adentrem no universo místico construído pelo texto, valorizando-se, a partir de suas leituras, os "lugares de incerteza" (JOUVE, 2012, 
p.150) abundantes no conto, de forma a nele encontrar, senão as respostas, as perguntas não satisfeitas pelo mundo real.

\section{Desenvolvimento da aula}

Entendendo, pois, a importância da Literatura no ensino e o papel que desempenha na formação crítica dos alunos, pretende-se, neste momento, apresentar estratégias didáticas de abordagem do conto roseano "A terceira margem do rio" em sala de aula.

Em princípio, é desejável que uma leitura prévia e individual do conto seja realizada por todos os alunos da turma. Este contato inicial com o texto é necessário ao sujeito leitor na medida em que, a partir dele, se estabelecerão algumas das "dimensões" mencionadas por Jouve, notadamente a afetiva e a cognitiva. A ocasião, portanto, é relevante para a elaboração das primeiras hipóteses interpretativas, sendo recomendável, para a otimização dessa etapa, encorajar a escrita de notas à margem do texto, de inspirações diversas.

Na primeira aula dedicada à análise, propor-se-ia uma leitura em voz alta do conto, devido à sua complexidade linguística, bem como ao fato de que "ler para o outro nunca é apenas oralizar um texto. Ledor e ouvinte dividem mais que a reprodução sonora do escrito, eles compartilham um interesse pelo mesmo texto, uma interpretação construída e conduzida pela voz, além de outras influências recíprocas." (COSSON, 2014, p. 104). No mesmo sentido, Daniel Pennac elenca os efeitos produzidos, no ouvinte, a partir da escuta de um texto lido competentemente em vOz alta:

Se ele lê verdadeiramente, põe nisso todo o seu saber, dominando seu prazer, se sua leitura é um ato de simpatia pelo auditório como pelo texto e seu autor, se consegue fazer entender a necessidade de escrever, acordando nossas mais obscuras necessidades de compreender, então os livros se abrem para ele e a multidão daqueles que se acreditavam excluídos da leitura vai se precipitar atrás dele. (PENNAC, 1993, p. 166).

A leitura em voz alta, portanto, abarca desde as camadas mais básicas de leitura, incluindo as de compreensão textual, até propriamente as camadas interpretativas, constituindo-se numa oportunidade para que, desde logo, identifiquem-se pontos a serem explorados ao longo da mediação. Em seguida, tendo dividido a sala em grupos, com a finalidade de instigar um trabalho de construção coletiva de sentido, eles exporiam as suas hipóteses iniciais de leitura, que compreendessem tanto uma possível explicação para o título 
“A terceira margem do rio" quanto a elaboração de um glossário, capaz de contemplar as questões espontaneamente surgidas a partir da discussão preliminar. Para esse fim, seria de utilidade, além da mediação do professor, a pesquisa em dicionários ou suportes eletrônicos. A escolha das novas tecnologias da informação e comunicação (TICs) como instrumento didático fundamenta-se na ideia de que elas possam contribuir no processo de ensinoaprendizagem, ainda que este seja um assunto controverso nas discussões mais recentes sobre o posicionamento da escola frente à era digital. Contudo, como lembra Rojo, "em vez de proibir o celular em sala de aula, posso usá-lo para comunicação, a navegação, a pesquisa, a filmagem e a fotografia" (2012, p. 27).

Posteriormente, de acordo com as exposições dos alunos, enquanto mediador de leitura, caberia ao professor apontar possíveis equívocos e extrapolações interpretativas, uma vez que o texto literário está sujeito a diferentes interpretações, mas não admite incoerências:

Se é conveniente encorajar a leitura subjetiva, é também conveniente ensinar os alunos a evitarem uma subjetividade desenfreada, fonte de delírio interpretativo. O problema da liberdade do leitor e dos limites da interpretação deve ser abordado em classe, mesmo que isso pareça ambicioso. [...] Eles são capazes de compreender que existem muitas maneiras de ler e que uma leitura socializada impõe regras. (ROUXEL, 2013, p. 22).

Feitas as reparações, na tentativa de imergi-los no universo ficcional do conto, o professor dirigiria perguntas aos alunos, formulando-as de modo preferencialmente indireto, no âmbito das questões surgidas a propósito da conversa prévia. O processo supõe, portanto, um movimento inicial, mais aberto, a partir do qual ele se torna gradativamente mais dirigido. Dentre as questões de interesse, a serem naturalmente filtradas ou adaptadas de acordo com as devolutivas iniciais da turma, teríamos as seguintes: "Qual o cenário da narrativa?”; "O que vocês pensam acerca da linguagem pela qual as personagens se expressam?”; "Vocês já tinham ouvido falar do autor? Se sim, o que ouviram?”; “Quais são as personagens do conto e quais suas impressões acerca delas?”; "Qual o perfil do narrador?” e "Qual, na opinião de vocês, é o principal conflito do conto?”. Nesse processo de imersão, os estudantes seriam incentivados a estabelecer relações entre as informações ficcionais e situações reais, as quais, vivenciadas ou não, fariam parte do conhecimento que têm do mundo. Isto é, a partir das inquietações dos alunos, a discussão seria aprofundada por um viés teórico. 
Sobre o cenário, conviria apresentá-lo como uma região não especificada, mas identificável como sendo o mundo da infância e mocidade do autor, o sertão de Minas (RÓNAI, 1981, p. XXIV-V). Dessa forma, o professor poderia contextualizar brevemente o Movimento Regionalista, abordando, junto a essa questão, a linguagem empregada no conto, a qual não se restringe à simples reprodução de um falar sertanejo, mas se apropria dele visando à criação do que Rónai denomina "insólitas locuções individuais” (1981, p. XXXIII), uma vez que, para além de expressões pouco utilizadas comumente como "entestou", “achaques", ou neologismos como "demoramento" e "subimento", encontramos a presença constante de expressões que, repetidas em seu caráter insólito, reforçam a dimensão fantástica dos próprios acontecimentos do texto. É bom lembrar, contudo, que muito desse aspecto criativo já terá sido abordado, muito provavelmente, pelos próprios alunos, especialmente na etapa em que, se valendo de instrumentos de pesquisa como dicionários ou a web, terão visto frustradas, em parte, algumas de suas consultas, na uma vez que várias expressões, justamente por neologísticas ou inusuais, não se encontram dicionarizadas. $O$ aparente fracasso (ao menos parcial) dessas pesquisas revela-se funcional, entretanto, em dois níveis: primeiro, para reforçar ou, se for o caso, introduzir o próprio conceito de "neologismo" e, segundo, para ilustrar, precisamente, um dos níveis transgressivos de que o texto literário, como lembra as OCEM, legitimamente se reveste enquanto forma de arte. Nesse âmbito, é coerente recorrer ao próprio texto literário em questão, evidenciando pelo menos um trecho no qual se evidencia essa insolidez linguística:

Sou homem de tristes palavras. De que era que eu tinha tanta, tanta culpa? Se o meu pai, sempre fazendo ausência: e o rio-rio-rio, o rio-pondo perpétuo. Eu sofria já o começo - esta vida era só o demoramento. Eu mesmo tinha achaques, ânsias, cá de baixo, cansaços, perrenguice de reumatismo. (ROSA, 1981, p. 31).

Em relação às personagens, valeira a pena destacar traços que lembram a antiga estrutura patriarcal no Brasil, ainda presentes no interior do país, como lembra Ana Paula Pacheco:

O respeito do mais novo pelo mais velho, o direcionamento da vida do filho espelhada na do pai, num sistema de produção rural onde pouco varia o papel e o lugar reservado a cada indivíduo no grupo, lembra uma ordem social fundada em laços patriarcais, com costumes arraigados. (PACHECO, 2006, p. 147). 
A ausência do pai na ficção e, por conseguinte, a maior responsabilidade da mãe na criação dos filhos, provavelmente, seria um aspecto, com o qual, boa parte dos alunos se identificaria ou reconheceria como recorrente na sociedade. Pela mitificação da situação corriqueira do abandono paterno, esses leitores estariam diante da "[...] descoberta de uma gama de sentimentos que a elaboração poética tramou, desvendou e criou em torno de um fato [...]" (OSAKABE, 2008, p. 51). Dados externos, como os indicadores sociais sobre a mulher, fornecidos pelo IBGE, poderiam ser somados à discussão, permitindo uma abordagem interdisciplinar no estudo, como previsto nos documentos oficiais. ${ }^{3} \mathrm{O}$ movimento se reveste de importância na medida em que o ensino de literatura, ao menos potencialmente, vincula-se à maturação afetiva dos alunos e, portanto, ao desenvolvimento de sua autonomia enquanto sujeitos. Em outras palavras, "como os problemas do homem e do mundo não são simples, precisam de soluções complexas, interdisciplinares." (NEVES, 2015, p.482)

Em seguida, é conveniente que a sala seja conduzida a refletir acerca das razões e dos efeitos discursivos da narração em primeira pessoa: a priori é possível perceber, como discorre Del Farra (1978, p. 51), que o enredo ganha sentido a partir da voz do narrador, restrita à percepção que ele tem dos acontecimentos e que oculta e desvela o que lhe convém. Concomitantemente, pode-se notar que o fato do narrador se posicionar como um "eu" permite ao leitor estabelecer um contato mais direto com o texto, bem como ser evidenciada a aproximação simbólica, quase fatídica, entre o filho (narrador) e o pai (aquele sobre quem se narra):

\footnotetext{
'A terceira margem do rio' é uma narrativa em primeira pessoa; essa escolha técnica convencional concentra uma peculiaridade que não passa despercebida ao leitor: a voz que conta a história do pai conta também a sua, à sombra deste, um trajeto em que a demora e a inércia tomaram o lugar das decisões. Entre testemunha e protagonista, o filho não tem nem um recuo do primeiro, dado pela clara distinção entre eu e outro, nem a relevância do segundo, e fica, também ele, no meio do caminho." (PACHECO, 2006, p. 158).
}

Retomando um aspecto já salientado no início da aula proposta, destaca-se a oportunidade do docente, a partir das respostas que os alunos deram em relação ao possível sentido do título, abordar o caráter insólito do conto. Tomando como pressuposto a inexistência de uma terceira margem do rio (nas palavras de Limia, "a margem que não se fixa, maleável, mutante, que não cria normas e, portanto, não aprisiona.” ( 2000, p. 327)), 
seria possível indagar, então, acerca da racionalidade e/ou irracionalidade do narrado. Desse modo, no tocante ao principal conflito do conto, seria de interesse indagar se a incoerência do título estaria, possivelmente, relacionada ao suposto transtorno mental do pai do narrador, bem como se o filho, cogitando tomar a mesma atitude do pai, substituindo-o na terceira margem, teria também enlouquecido. O conceito de loucura, assim, seria posto no centro da discussão, permitindo questionar, por exemplo, se todas as atitudes do homem, dispondo de pleno estado mental, seriam motivadas pela razão, e mesmo na difícil precisão do limiar entre a sanidade e a loucura. Para melhor discorrer acerca da relatividade da loucura, evocada direta e indiretamente no texto, seria interessante mencionar obras como Elogio da loucura (1511) de Erasmo de Rotterdam, a História da Loucura na Idade Clássica (1972) de Michel Foucault e até mesmo a peça shakespeariana Hamlet (1602), obras que, respectivamente, satirizam, teorizam e tematizam a loucura (ainda que fingida), demonstrando o quão frutífero tem sido esse tema nos campos filosófico, religioso e literário. Em relação à literatura brasileira, especificamente, nunca seria demais remeter ao conto O Alienista, de Machado de Assis, ficando a cargo do professor graduar a quantidade de informações oferecidas a seu respeito, posto que a leitura da obra, em momento posterior, pode ser instigada ou orientada a partir dessa intervenção a propósito de Rosa.

A propósito do desfecho surpreendente do conto, seria pertinente questionar os alunos acerca de aspectos que reforçam o teor insólito ou mesmo sobrenatural do texto. Interessa, por exemplo, inquirir do que, possivelmente, o narrador foge ao final do conto, ou, mais especificamente, pelo que a personagem se culpa e do que tem medo. Seria conveniente, pois, reler os dois parágrafos finais da narrativa, nos quais se evidencia o temor que o filho sente do pai e do "além" que ele representa, um além que é a morte em vida. Explorar os possíveis sentidos dessa "morte em vida", bem como, de modo mais geral, a relação que o ser humano trava com a morte, consiste aqui num aspecto de relevo, especialmente porque, numa das chaves de leitura do conto, a terceira margem do rio pode ser pensada como o desconhecido, que permeia e oprime a existência do homem em sua travessia pela vida rumo à morte. ${ }^{4}$ Contudo, admitindo-se que o conto permanentemente agencia variados "lugares de incerteza", construindo-se por meio de lacunas e sugestões frequentemente indiretas, cabe ao professor atentar para os limites e condições de possibilidade da leitura aqui encaminhada, a ser enriquecida e mesmo confrontada por abordagens concorrentes, surgidas naturalmente ao longo da discussão. 


\section{Proposta de atividades}

A fim de consolidar as reflexões produzidas na leitura crítica, o docente poderia propor aos alunos diversas atividades avaliativas. A ideia é que, por meio delas, o estudante possa retomar aspectos discutidos nas etapas anteriores, operando as seleções, reconfigurações e ampliações necessárias para a boa execução da proposta. Aqui, apenas sugerem-se três encaminhamentos dentre muitos possíveis, ora valorizando-se movimentos analítico-interpretativos ancorados em leituras comparativas, ora valorizando-se incursões propriamente criativas, que necessariamente dão notícia, também, de uma dada interpretação do conto roseano. Para todos eles, convém lembrar que o acompanhamento do professor deve se estender pelo processo como um todo, dividindo-o em etapas mediante as quais seja possível, em conjunto com os alunos, avaliar o andamento parcial da proposta e planejar, com base nesse diagnóstico, os passos subsequentes. Dito isto, algumas das atividades poderiam consistir nas seguintes:

1) Em grupos de até cinco integrantes, efetuar uma adaptação paródica ou estilizada do conto (peça teatral, vídeo, animação, história em quadrinhos). Importa avaliar o processo como um todo, desde a ideia original, passando pela confecção de storyboard ou de roteiros, quando for o caso, até o produto final.

2) Em duplas ou trios, selecionar qualquer produção artística (literária, musical, cinematográfica) relacionada à temática do conto estudado. Novamente, interessa acompanhar o processo desde a seleção do objeto a ser comparado, passando pelos aspectos efetivamente a serem realçados na associação, até a entrega da versão final do trabalho, que deve ser apresentado à turma.

3) Elaborar uma análise comparativa, individualmente ou em dupla, entre o conto e a animação dirigida por Alê Abreu, O menino e o mundo (2014), com a finalidade de traçar semelhanças e diferenças entre as duas produções artísticas. $\mathrm{Na}$ animação $\mathrm{O}$ menino e o mundo, a ausência paterna é a grande desencadeadora do enredo: o menino, sentindo falta do pai, o qual sai do campo em busca de um trabalho na cidade, parte para conhecer o novo mundo para onde foi seu progenitor, encontrando miséria, pobreza, desigualdade, mas também esperança de um renascer. Aos olhos do menino, a vida é uma travessia da infância à velhice, é o desconhecido - a "terceira margem do rio" - ao qual o homem está condicionado. Além da temática da ausência paterna, a língua portuguesa aparece substituída por uma língua não convencional e inventada, donde se percebem, de imediato, duas frentes possíveis de exploração do conto e da animação, respeitando-se as suas respectivas especificidades. Para 
essa atividade, também seria solicitada a entrega da versão escrita do trabalho e a apresentação da análise produzida aos companheiros de classe, depois, naturalmente, de o professor acompanhar o processo de elaboração como um todo.

Ao final, depois das apresentações, seria promovido um último debate com a sala, no qual seria discutido o processo de elaboração dos trabalhos, suas produções e impressões de leitura, observando-se a manutenção de um clima favorável ao diálogo, sendo este essencial à formação de sujeitos leitores: "[...] um contexto onde reinam a confiança, o respeito e a escuta mútuos é propício ao encontro com os textos literários - e é mesmo determinante." (ROUXEL, 2013, p.30)

\section{Considerações finais}

Conclui-se que é essencial ao professor de literatura a reflexão e a fundamentação teórica de sua prática, tal qual o reconhecimento de seu papel enquanto mediador na dinâmica leitor e obra, como previsto nos documentos oficiais. Assim, efetuando possíveis acomodações como as sugeridas na proposta apresentada, o professor estimularia o aluno a se posicionar criticamente frente a diferentes discursos, desenvolvendo suas habilidades e competências leitoras.

Espera-se, dessa forma, que a abordagem apresentada do conto “A terceira margem do rio" seja uma alternativa, dentre muitas outras, de atender as diversas necessidades dos alunos em suas peculiaridades, bem como que contribua para o amadurecimento literário e mesmo afetivo da turma, tendo em vista que o contato, devidamente mediado, com um texto tão rico em possibilidades interpretativas, tende a evocar sentimentos com os quais as pessoas, em situação de ensino-aprendizagem ou não, convivem cotidianamente, bem como conhecimentos vários acerca do mundo em que vivem.

Em um contexto de sala de aula, permitir que os alunos façam intervenções, questionem, utilizem dos meios dos quais dispõem para a melhor compreensão textual (como as novas tecnologias, mas não apenas elas) e relacionem um conto produzido no século XX a dilemas contemporâneos permite, desde que tais movimentos se deem segundo uma organização e gradação pertinentes, que a literatura seja valorizada e cumpra o seu papel formador na educação, em contraste com o que se concebe, de modo redutor, como "pedagogia oficial": 
A literatura pode formar; mas não segundo a pedagogia oficial, que costuma vê-la ideologicamente como um veículo da tríade famosa, - o Verdadeiro, o Bom, o Belo, definidos conforme os interesses dos grupos dominantes, para reforço da sua concepção de vida. Longe de ser um apêndice da instrução moral e cívica, [...] ela age com o impacto indiscriminado da própria vida e educa como ela, - com altos e baixos, luzes e sombras. (CANDIDO, 1999, p.84).

\section{Notas}

1 Tese formulada por Gilles Thérien (1990) em sua obra Pour une sémiotique de la lecture.

2 “A leitura é o processo no qual o leitor realiza um trabalho ativo de compreensão e interpretação do texto, a partir de seus objetivos, de seu conhecimento sobre o assunto, sobre o autor, de tudo o que sabe sobre a linguagem etc. Não se trata de extrair informação, decodificando letra por letra, palavra por palavra. Trata-se de uma atividade que implica estratégias de seleção, antecipação, inferência e verificação, sem as quais não é possível proficiência.” (BRASIL, 1998, p.69).

3 As Orientações Curriculares para o Ensino Médio (OCEM) afirmam que “[...] nos programas pedagógicos são reforçadas as propostas de interdisciplinaridade, transdisciplinaridade, transversalidade. O intuito delas é promover a expansão da compreensão de mundo, pois pretendem ensinar os alunos a entender as relações entre as disciplinas pedagógicas - em vez de ensinar as matérias escolares de maneira isolada, ou seja, voltadas para si mesmas - e as disciplinas escolares, e delas com a sociedade e a vida dos alunos. O resultado esperado deve reverter para a compreensão da complexidade social em que vivem os cidadãos (no caso, alunos, professores, pais, familiares), sendo a questão da diversidade um dos componentes dessa complexidade." (BRASIL, 2006, p. 94)

4 “Sob a lei do insólito, o familiar torna-se estranho (o pai-fantasma, sombra do pai conhecido) [...]" (PACHECO, 2006, p. 153)

\section{Referências}

BRAGANÇA, Soraya Patrícia Rossi. O inferno em “A terceira margem do rio". In:

DUARTE, Lélia Parreira (Org.). Veredas de Rosa. Belo Horizonte: PUC-MG, 2000, p. 662665.

BRASIL. Parâmetros curriculares nacionais: Terceiro e quarto ciclo do ensino fundamental: língua portuguesa. Brasília: MEC/SEF, 1998.

. Orientações curriculares para o ensino médio. Brasília: MEC/Secretaria da Educação, 2006. 
CANDIDO, Antonio. A literatura e a formação do homem. Remate de Males. Revista do Departamento de Teoria Literária IEL/ UNICAMP, Número Especial Antonio Candido. Campinas, Anual, 1999, p. 81-90.

COSSON, Rildo. Círculos de leitura e letramento literário. São Paulo: Editora Contexto, 2014.

DALVI, Maria Amélia. Literatura na Escola: propostas didático-metodológicas. In: DALVI, Maria Amélia; REZENDE, Neide Luzia; JOUVER-FALEIROS, Rita. Leitura de literatura na escola. São Paulo: Parábola, 2013. p. 67-97.

DAL FARRA, Maria Lúcia. O narrador ensimesmado: o foco narrativo em Vergílio Ferreira. São Paulo, Ática, 1978.

JOUVE, Vicent. O que é leitura? In: - A leitura. São Paulo: Editora da Unesp, 2002. cap. 1, p. 17-33. Por que estudar literatura? São Paulo: Parábola, 2012.

LIMIA, Júlia. A terceira margem do rio. In: DUARTE, Lélia Parreira (Org.). Veredas de Rosa. Belo Horizonte: PUC-MG, 2000, p. 327-331.

NEVES, Carmen Moreira de Castro. Formação de professores da educação básica e pósgraduação: a interdisciplinaridade necessária. In: FERNANDES, Valdir; PHILLIPPI JÚNIOR, Arlindo. Práticas da interdisciplinaridade no ensino e pesquisa. 2015, p. 471-499.

OSAKABE, Haquira. Poesia e indiferença. PAIVA, Aparecida (Org.) et al. Leituras Literárias: discursos transitivos. Belo Horizonte: Ceale/ Autêntica, 2008, p. 37-54.

PACHECO, Ana Paula. Lugar do mito: narrativa e processo social nas Primeiras estórias de Guimarães Rosa. São Paulo: Nankin, 2006.

PENNAC, Daniel. Como um romance. (trad. Leny Werneck). Rio de Janeiro: Rocco, 1993. 
ROJO, Roxane; ALMEIDA, Eduardo de Moura (Org.). Multiletramentos na escola. São Paulo: Parábola editorial, 2012.

ROUXEL, Annie. Aspectos metodológicos do ensino da literatura. In: DALVI, Maria Amélia; REZENDE, Neide Luzia; JOUVER-FALEIROS, Rita. Leitura de literatura na escola. São Paulo: Parábola, 2013, p. 17-33

RÓNAI, Paulo. Os vastos espaços. In: ROSA, João Guimarães. Primeiras estórias. Rio de Janeiro: José Olympio, 1981, p. XX-XLVI.

ROSA, J. G. A terceira margem do rio. In: Primeiras estórias. Rio de Janeiro: José Olympio, 1981, p. 27-32.

recebido em 01 out. 2018 / aprovado em 19 nov. 2018

Para referenciar este texto:

NETO, J. S. V.; BERTÃO, L. S. P.; KIKUCHI, N. M. D. Entre margens: Guimarães Rosa na sala de aula. Dialogia, São Paulo, n. 30, p. 47-58, set. /dez. 2018. Disponível em: $<$ https://doi.org/10.5585/Dialogia.n30.10626> 


\title{
Ensino de história, planejamento e autoria: experimentações com literatura negra em estágios curriculares obrigatórios
}

\author{
Teaching history, planning and authorship: experiments with black literature in \\ compulsory curricular stages
}

\begin{abstract}
Carla Beatriz Meinerz
Doutora em Educação pela Universidade Federal do Rio Grande do Sul. Docente do Programa de Pós-Graduação em Educação da Faculdade de Educação da Universidade Federal do Rio Grande do Sul. Rio Grande do Sul - RS - Brasil carlameinerz@gmail.com

Fernanda Amorin Golembiewski Especialista em Ensino de História e Geografia pela Universidade Federal do Rio Grande do Sul. Rio Grande do Sul - RS - Brasil fernanda.golembiewski@ufrgs.br

Raisa da Silva Oyarzabal Especialista em Ensino de História e Geografia pela Universidade Federal do Rio Grande do Sul. Rio Grande do Sul - RS - Brasil raisa.oyarzabal@ufrgs.br
\end{abstract}

\begin{abstract}
Resumo: Objetiva analisar a autoria do professor de história na criação de aulas, através da construção de planejamentos conectados com literaturas, histórias e culturas africanas e negras. Resulta de reflexões a partir de práticas metodológicas de ensino e pesquisa com documentos de estágios curriculares obrigatórios do curso de Licenciatura em História da UFRGS. Problematiza a presença étnico-racial hegemônica nos saberes expressos nesses planejamentos. Como referência no campo específico do ensino de História, utiliza a autora Ana Maria Ferreira da Costa Monteiro e, no campo geral da Educação e formação de professores, o autor Maurice Tardiff. No campo da literatura, fundamenta-se nos escritos do pensador Luiz Silva (Cuti). Os resultados parciais apontam a recorrência do uso de narrativas históricas e literárias vinculadas aos conteúdos de história e cultura africana e afro-brasileira, com menos enunciação do diálogo entre saberes distintos e da educação das relações étnico-raciais.
\end{abstract}

Palavras-chave: Ensino de História. Literatura. Planejamento. Autoria. Estágios Curriculares Obrigatórios.

\begin{abstract}
It aims to analyze the authorship of the history teacher in the creation of classes, through the construction of plans connected with black and African literatures, histories and cultures. It results from reflections from methodological practices of teaching and research with documents of compulsory curricular internships of the course of Degree in History of UFRGS. It problematizes the hegemonic ethnic-racial presence in the knowledge expressed in these plans. As a reference in the specific field of teaching History uses the author Ana Maria Ferreira da Costa Monteiro and, in the general field of
\end{abstract}


Education and teacher training, the author Maurice Tardiff. In the field of literature it is based on the writings of the thinker Luiz Silva (Cuti). The partial results point to the recurrence of the use of historical and literary narratives linked to the contents of African and Afro-Brazilian history and culture, with less enunciation of the dialogue between distinct knowledge and the education of ethnic-racial relations.

Keywords: History Teaching. Literature. Planning. Authorship. Compulsory Curricular Internships.

\section{Considerações Iniciais acerca da presença das temáticas negras nas aulas de história}

Começamos nossa escrita com um trecho do conto "Boneca" de Luiz Silva (Cuti) (2016, p. 44):

\footnotetext{
Não. Por gentileza, eu estou procurando uma boneca...

Temos várias. Olha aqui a Barby, a Xuxinha... E a loirinha foi apanhando diversas bonecas. Colocava-as sobre o balcão, como se escolhesse para si. Olha que gracinha esta aqui de olhos azuis! É novidade. Chegou ontem e já vendeu quase tudo. Chora, tem chupeta, faz pipi... E essa outra aqui? Não é uma graça? E levou ao colo a ruivinha de tom amarelado, bem clarinha. Mexeu-lhe os bracinhos e as perninhas e indagou: Não gostou de nenbuma?

É que estou procurando uma boneca negra...

Tem sim! - o dono da loja dirigia-se à empregada: Procura melhor, na prateleira de baixo, lá em cima mesmo, perto da pia.
}

Inspirando-nos na metáfora literária que conta a trajetória de um pai em busca de uma boneca negra para presentear sua filha nos festejos natalinos, indagamos sobre a presença das temáticas negras nas aulas de história. Vamos contar trajetórias de buscas da presença negra nos planos de jovens professores em formação, inquiridos a tratar de educação das relações étnicoraciais em suas aulas. A partir de reflexões construídas em análise de experimentações realizadas nos estágios curriculares obrigatórios do curso de Licenciatura em História da Universidade Federal do Rio Grande do Sul (UFRGS), tratamos da importância da autoria do professor de história no momento de criar suas aulas, por meio de planejamentos com uma perspectiva participativa, interativa e emancipatória. A pergunta central de nossa escrita é: Qual a presença étnico-racial hegemônica nos saberes expressos nesses planejamentos?

Nosso foco analítico centra-se na relação pedagógica interativa, dialógica e emancipatória (FREIRE, 1996), considera o protagonismo do jovem estudante na relação com os diferentes saberes que circulam no processo de aprendizagem (CHARLOT, 2000). O jovem estudante é compreendido em seu lugar válido de fala dentro desse processo dialógico, interlocutor ativo na 
negociação de saberes históricos (MONTEIRO; PENNA, 2011). Buscamos compreender as escolhas epistemológicas que destacam o protagonismo de pensadores negros nos planos dos professores estagiários, a partir do que aprendemos com os saberes construídos nas lutas por emancipação, forjadas pelo movimento negro educador no Brasil (GOMES, 2017). Tais aprendizagens levam à descolonização dos currículos (GOMES, 2012), demarcada pelos marcos legais instaurados a partir da Lei 10.639/03, que institui a obrigatoriedade do ensino de histórias e culturas negras e afro-brasileiras na educação nacional.

O presente estudo se coloca na perspectiva que Nilma Lino Gomes (2017), inspirada na sociologia proposta por Boaventura de Sousa Santos, nomeia como pedagogia das emergências: aquelas que reconhecem e tornam credíveis os saberes produzidos, articulados e sistematizados pelo movimento negro para a prática e para o pensamento educacional. Observa a relação dessa formulação com as pedagogias decoloniais, nascidas das lutas, resistências e práticas insurgentes (WALSH, 2013). As pedagogias das emergências criam a tensão necessária para o rompimento das pedagogias das ausências (GOMES, 2017), aquelas que produzem intencionalmente o ausente, o não existente, o não credível. Trata-se, nesta análise, de destacar as ausências e permanências da educação das relações étnico-raciais nos planos e práticas docentes relativas aos estágios curriculares obrigatórios de ensino de história. Enfocamos a interação com saberes diversos, buscando na literatura negro-brasileira (SILVA, 2010), e no diálogo com os movimentos sociais, a fundamentação para práticas conectadas com uma história plural e uma ecologia de saberes (SANTOS, 2010).

A literatura negro-brasileira, segundo Silva (2010), marca a presença de personagens, autores e leitores negros e negras, creditando e valorizando positivamente os saberes dos sujeitos da diáspora africana no Brasil. Para o autor, "a literatura é poder, poder de convencimento, de alimentar o imaginário, fonte inspiradora do pensamento e da ação.” (p. 12). Como fazer humano e plural, ela experimenta o racismo e a luta antirracista em seu processo. No caso de nosso país, a produção literária negro-brasileira anuncia saberes que se expressam no "entrechoque das ideias e nos intercâmbios dos pontos de vista." (p. 13).

As narrativas literárias e históricas, na qualidade de conhecimentos sistematizados e relacionados aos currículos e ao ensino escolarizado, são práticas socioculturais mediadas pela linguagem e constituídas em relações de poder. Roland Barthes (1989), no clássico texto "Aula", ao argumentar acerca do fato de que a liberdade existe somente fora da linguagem, pergunta-se sobre o que, então, permitiria driblá-la, já que a linguagem não possui exterioridade. A resposta 
do pensador está na literatura, na escrita e no texto. Assim, "linguagem, em seu aspecto de aprisionamento, é combatida não pela mensagem de que ela é instrumento, mas pelo jogo de palavras de que ela é teatro (p. 17). Jogar com as palavras parece fundamental na relação pedagógica. Esse jogo pode ser intencionalmente pensado, através das escolhas epistêmicas realizadas nos textos dos planejamentos do educador.

A escrita que ora apresentamos surge como fruto das reflexões acerca das práticas docentes nos estágios de duas licenciandas que, no momento da escrita, atuavam como monitoras das atividades de ensino de Estágio de Docência em História I - Ensino Fundamental. Resulta igualmente de diálogos com uma docente universitária, responsável pelas atividades de ensino dos estágios curriculares obrigatórios de História. Conecta-se com resultados de pesquisa com base em análise documental produzida em relatórios de estágio. O recorte temporal da análise é circunscrito aos anos de 2013 e 2014, tendo como referência a metodologia que cruza relatos de experiências de estágio e monitoria em atividades de ensino em história, assim como a análise de relatórios de um grupo de professores em formação. $\mathrm{Na}$ análise documental qualitativa, compreende-se a produção de dados num conjunto de 48 relatórios de estágio, correspondendo aos estágios de ensino fundamental, realizados no segundo semestre de 2013.

\section{Planejamento como Processo Criativo: entre o protagonismo do estudante e a autoria do professor}

No curso de licenciatura em história da UFRGS, as atividades de ensino vinculadas à docência e aos estágios curriculares são realizadas na Faculdade de Educação, momento em que o licenciando é convocado a elaborar uma trajetória de ações e reflexões conectadas com suas vivências no espaço escolar, colocando-se como autor e criador de suas proposições políticopedagógicas. São ações obrigatórias dessas atividades: 1) a observação do espaço escolar e da turma em que será realizada a prática docente, através de aproximações com os diferentes atores da comunidade escolar; 2) a construção de um diagnóstico inicial com o perfil da turma, geralmente através de um questionário ou enquete realizado nos primeiros encontros com os estudantes; 3) a confecção de um plano geral, a partir de recortes teórico-metodológicos no campo da História e da Educação, evidenciando a busca por um foco temático para a prática docente realizada no acordo $^{1}$ com a escola, o professor de História e o orientador do estágio; 4) a 
confecção de planos específicos e de materiais didáticos próprios criados em processos de autoria e pesquisa; 5) a constante avaliação dos impactos das práticas propostas e possível reorientação das escolhas didáticas; 6) a visita de supervisão do estágio, acompanhada por um retorno ao licenciando sobre esse momento de observação; 7) a avaliação do estágio por parte dos jovens estudantes da escola; 8) a construção dos textos reflexivos finais: para o ensino fundamental trata-se de um relatório e, para o ensino médio, um artigo.

Em nossas experiências docentes buscamos construir os planejamentos valorizando o conceito de autoria e as possibilidades que ele pode propiciar para as aulas de história. A autoria dos recursos didáticos, que implica em escolhas feitas pelo professor, é entendida como uma potencialidade, na medida em que permite a construção de planejamentos para realidades específicas de turmas. Nesse sentido, é possível estabelecer um vínculo entre a autoria do professor e o protagonismo do estudante, mediadas pelos diálogos com literaturas diversas, capazes de consolidar uma ecologia de saberes (SANTOS, 2010).

A confecção de materiais didáticos de autoria do professor estagiário constitui uma das etapas importantes do estágio docente. Esses materiais devem ser elaborados a partir dos diagnósticos obtidos nas observações. Construir um material didático é um dos desafios da prática docente, pois torna necessário que o professor em formação saia da zona de conforto e do que está acostumado na rotina acadêmica - ou seja, textos longos e nem sempre didáticos - e pense em recursos adequados aos jovens da educação básica.

Os relatórios dos estágios, portanto, objetivam uma escrita que se constitui em um modo radical de expressar o pensamento reflexivo. Ela se torna uma expressão narrativa forte, pois através dela é possível avaliar, julgar, compreender e redimensionar os fatos e experimentações próprias do estágio, ao considerar uma relação do licenciando consigo mesmo - suas escolhas, impulsos, atitudes, omissões, alegrias e dúvidas. Tal expressão narrativa conecta-se com o jogo de tentativas de driblar os aprisionamentos que a própria linguagem nos coloca, conforme Roland Barthes (1989). Esse processo é constituído por intensos encontros e diálogos, entre os colegas em aulas presenciais, entre o supervisor e o estagiário em orientações individuais, entre os monitores e os estagiários em momentos virtuais ou presenciais. Nessa interação desenvolve-se a autoria docente.

Entendemos por autoria do professor, mesmo daquele em formação inicial, toda a ação que exija a opção por metodologias e teorias, o desenvolvimento dos próprios materiais didáticos, a seleção das abordagens historiográficas e dos recortes temáticos. Ressaltamos a estreita relação 
entre a ideia de protagonismo do estudante e de autoria do professor, por entendermos que o exercício da autoria nos permite construir propostas de ensino a partir da realidade que se apresenta na sala de aula e do conhecimento das turmas para as quais essas propostas são pensadas. Nesse sentido, nossa contribuição para a área de ensino de história é reafirmar que a prática docente não é vazia de teoria, e que o professor possui um saber específico - o saber docente. Sobretudo, não é vazia de opções políticas e pedagógicas. Ao escolher, por exemplo, uma literatura negro-brasileira (SILVA, 2010), o professor opta por saberes construídos pelos negros e não sobre os negros, apostando na sua emancipação e valorização.

Para Tardiff \& Lessard (2011), o sentido do trabalho do professor não pode ser construído independentemente dos outros atores do cotidiano com os quais trabalham os docentes, no caso, os alunos. Nessa perspectiva, fundamentamos a ideia de autoria docente e protagonismo estudantil. É preciso levar em conta a pluralidade das experimentações dos jovens alunos, buscando conhecer seus pertencimentos comunitários, familiares, grupais, religiosos, igualmente as relações de classe, de gênero e étnico-raciais em que estão envolvidos. Por vezes, nessa interação acabamos por construir espécies de acordos entre mundos distintos, entre saberes diferenciados. É nessa negociação (MONTEIRO; PENNA, 2011) entre os saberes próprios dos jovens e os saberes específicos dos professores que está a habilidade própria do docente.

O planejamento em educação é uma temática que envolve diferentes concepções e abordagens. Entendemos aqui o planejamento como processo de autoria e criatividade que pressupõe escolhas permeadas pelas opções teóricas e metodológicas de seus proponentes. No caso do ensino de história, são escolhas no campo da História e no campo da Educação. Para Monteiro e Penna (2011), o ensino de história deve ser pensado como um "lugar de fronteira", utilizando-se de referenciais e conceitos desses dois campos. Nesse aspecto, não pensamos mais a partir da tradição cartesiana do método, constituída no contexto do pensamento moderno, em que planejar era praticar e organizar técnicas para alcançar resultados exatos: um bom plano, com boas técnicas, resultaria no alcance de bons resultados. Isso não significa negar o valor de ações planejadas e contextualizadas, em que teoria e prática são indissociáveis. Não se trata mais de construir e depois usar um bom plano ou um bom método, e sim de decidir ou selecionar teorias e metodologias, dentro de um contexto de produção cultural e de relação político-pedagógica. 


\section{A Autoria Docente e o Protagonismo dos Alunos nas Experiências de Estágios Obrigatórios}

Para Tardiff e Lessard (2011), o ensino escolar vem desempenhando historicamente o papel de filtro entre a sociedade e a cultura, por um lado, e as jovens gerações, por outro lado. Esse desempenho tem sido parte do que representa a especificidade do ofício do professor. Porém, na atualidade, para os autores,

O que é novo é a aceleração da transformação, tanto da sociedade quanto da cultura, o que torna a função da escola certamente tão importante quanto foi outrora, e até mais, porque ela atinge todos os membros de uma geração e por mais tempo do que outrora, porém mais arriscada e difícil para os docentes, porque os materiais de construção do trabalho são menos garantidos do que antes. (LESSARD; TARDIFF, 2011, p. 277).

Sabemos que as condições de trabalho da maioria dos professores no Brasil não garantem, em termos salariais, pedagógicos, temporais, espaciais e infraestruturais, o exercício do ofício de maneira qualificada e capaz de atender às exigências da contemporaneidade. No entanto, nossa escrita parte da premissa de que o momento do estágio curricular obrigatório tende ainda a criar ambientes e exigências capazes de construir práticas qualificadas e "inéditos viáveis" (FREIRE, 1996). Apontamos então para o que seja possível. A partir deste momento, sistematizamos dois relatos de práticas docentes de ensino de História na Educação Básica, constituídas nesse processo de estágio, cujo foco é o desejo de construir autoria do professor e protagonismo do aluno. A seguir, construiremos apontamentos parciais sobre eles, na conexão com análise documental de planejamentos de 48 relatórios de estágio.

Relato Primeiro²: Realizei as minhas duas práticas de estágio na minha cidade - Viamão -, que fica na região metropolitana de Porto Alegre, em turmas distintas, uma delas na Educação de Jovens e Adultos. Destaco aqui o quão importantes foram as doze horas de observação para entender o funcionamento da escola, bem como o andamento e o desempenho das turmas. Mas, além da observação, foi fundamental para a construção do planejamento a aplicação de um questionário individual. Este planejamento não foi livre, mas adaptado ao que foi pedido pelo professor titular, com centralidade na narrativa histórica centrada na Europa. Os planejamentos foram construídos a partir das especificidades de cada turma, sempre trazendo o aluno para o 
protagonismo das aulas. Foi desafio do planejamento deste estágio (re)construir parte do conhecimento histórico dos alunos, trazendo narrativas de cultura e história africana e afrobrasileira.

Relato Segundo ${ }^{3}$ : Minhas duas experiências de estágio tiveram em comum a escolha da mesma temática como central nos planejamentos: a História da África. O objetivo dessa escolha justificou-se a partir da Lei 10.639/03 e da intenção de atuar na construção de relações étnicoraciais baseadas no respeito à diversidade e no combate ao racismo. Nos dois planejamentos, a primeira unidade de trabalho trouxe questionamentos a respeito dos saberes dos alunos sobre a África e acerca do ensino da história desse continente - buscando compreender de que forma ele está sendo (ou não) contemplado nas escolas. A autoria foi priorizada nos dois estágios docentes, apresentando-se como um recurso importante para possibilitar a participação e o protagonismo dos estudantes nas aulas. Os materiais elaborados incluíram textos didáticos, mapas do continente africano, exibição de vídeos e proposição de roteiros de análise para os mesmos. A utilização de questionários aplicados no início dos estágios, mencionada anteriormente como uma ferramenta para pensar na relação entre autoria do professor e protagonismo do estudante, foi uma importante ferramenta utilizada nas experiências desse relato. Uma das questões proposta aos alunos no questionário foi “o que você conhece sobre a África e sua história?”. A partir da pergunta, foi possível analisar, antes de iniciar a discussão sobre o assunto, os saberes dos estudantes a respeito do tema, subsidiando as futuras discussões que seriam construídas ao longo do estágio. O uso de poemas e narrativas literárias sobre a África gerou importantes evocadores de memória para a construção de conhecimentos.

Sintese de palavras-chave encontradas em escritas de relatórios de práticas docentes: ao buscar palavraschave nas narrativas dos estagiários de 2013/2, referentes a temas de histórias e de culturas africanas e afro-brasileiras, ao conceito de educação das relações étnico-raciais ou à legislação, encontramos os seguintes resultados ou incidência das mesmas: cultura afro-brasileira (5), reinos africanos (3), escravidão (2), educação para a diversidade (2), história da África (1), Lei no 10.639/03 (1), consciência negra (1), Educação das Relações Étnico-Raciais (1), Preconceito e discriminação (1), resistência negra (1), tráfico de escravos (1), questões étnico-raciais (1), quilombos (1), reinos africanos (1), África (1), Zumbi dos Palmares (1). O uso de textos literários ou de autores referenciados como negros ainda é minoritário em relação ao uso de fontes historiográficas e de livros didáticos. Em relação aos planejamentos de ensino, observou-se a inclusão de temas referentes à Lei $n^{\circ}$ 10.639/03 (BRASIL, 2003) ou às propostas das Diretrižes 
(BRASIL, 2004), em 18 exemplos, no conjunto total de 48 planejamentos componentes dos relatórios de estágio. Nos demais, ou seja, em 30 planejamentos, não se observou a inclusão desses temas e/ou propostas. Na análise dos planejamentos de ensino, associada aos demais materiais componentes dos relatórios de estágio, observou-se a inclusão de temas relativos à: história africana; história dos afro-brasileiros; cultura africana; cultura afro-brasileira.

\section{Considerações Parciais}

Qual a presença étnico-racial hegemônica nos saberes expressos nessas práticas de ensino e nesses planejamentos? Os resultados parciais apontam a pequena recorrência do uso de narrativas históricas e literárias vinculadas aos conteúdos de história e cultura africana e afrobrasileira, com menos enunciação do diálogo entre saberes distintos e da educação das relações étnico-raciais. $\mathrm{Na}$ proposta desta análise, os planejamentos configuram-se como o que nomeamos de pedagogia das ausências (GOMES, 2017). Observamos que o conceito pedagogia das emergências.

Segundo pesquisadoras que tratam das produções nessa área, como Selva Guimarães Fonseca (1995; 1997) e Flavia Eloísa Caimi (2001; 2008), convivemos com uma diversidade de maneiras de pensar e de fazer o ensino de história. Caimi (2008) faz uma imersão investigativa nas memórias e relatos de estagiários de cursos de licenciatura em História durante a realização de suas práticas docentes, propondo a superação do caráter técnico-instrumental, que é tradicionalmente atribuído aos estágios dessa natureza, e assumindo a reflexão teóricometodológica como instância cognitivo-explicativa do trabalho docente. Em estudo sobre o modo pelo qual os professores de história mobilizam seus saberes na prática docente, Monteiro (2007) também observa que o significado da docência se relaciona com o compromisso da formação de cidadãos críticos. Monteiro sugere que esta seja "uma característica da identidade profissional dos professores de História, este compromisso com a dimensão formadora do ensino" (MONTEIRO, 2007, p. 66). Tal perspectiva relaciona-se com a experiência de vida de cada sujeito.

No caso do uso de narrativas históricas e literárias construídas por meio do protagonismo das epistemologias negro-brasileiras, observa-se, como resultados dos dados aqui analisados, uma tensão entre ausências e emergências (GOMES, 2017). 
Nossas experiências docentes - diferentes entre si e igualmente enriquecedoras - nos mostram que a escolha pela autoria apresenta muitas potencialidades ao professor de História, como uma ferramenta transformadora em suas aulas, pois possibilita que seus alunos sejam sujeitos protagonistas na construção do seu conhecimento, já que seus saberes e vivências são considerados na construção dos planejamentos. Essa autoria pressupõe opções políticopedagógicas, capazes de reiterar a pedagogia das ausências ou evocar a pedagogia das emergências. $\mathrm{Na}$ qualidade de emergentes estão os saberes emancipatórios construídos historicamente nas lutas das pessoas negras no Brasil, representadas por importantes intelectuais, poetas, contistas.

Nossa proposta construiu um olhar direcionado às escolhas teórico-metodológicas e às formas como se inserem, em planejamentos ou em currículos, a complexidade dos processos históricos. Desse modo, foi possível apenas anunciar a compreensão das apropriações das obrigatoriedades legais pelos sujeitos envolvidos na educação.

Concluímos com a inquietação de que a busca da aplicação desses marcos legais, constituídos a partir da Lei 10.639/03, ainda tem por premissa hegemônica um lugar de fala que trata do outro e não com o outro, trata antes das narrativas e literaturas sobre os negros do que pelos negros e com os negros. Uma dialogia emancipatória, por nós defendida, aposta no diálogo e na interação entre diversos sujeitos e saberes como um caminho para a educação das relações étnico-raciais.

\section{Notas}

${ }^{1} \mathrm{O}$ planejamento pensado como um acordo pressupõe uma negociação entre as partes já referidas. Nesse caso, não há plena autonomia no exercício da autoria na construção do planejamento. O planejamento muitas vezes é uma negociação que acaba não proporcionando a livre autoria em todas as suas possibilidades e sim uma autoria limitada.

${ }^{2} \mathrm{O}$ relato é feito na primeira pessoa do singular para evidenciar a autoria da licencianda.

3 O relato é feito na primeira pessoa do singular para evidenciar a autoria da licencianda. 


\section{Referências}

BARTHES, Roland. Aula. São Paulo: Editora Cultrix, 1989.

BRASIL. Lei n. 10.639 de 09 de Janeiro de 2003. Altera a Lei no 9.394, de 20 de dezembro de 1996, que estabelece as diretrizes e bases da educação nacional, para incluir no currículo oficial da Rede de Ensino a obrigatoriedade da temática "História e Cultura Afro-Brasileira", e dá outras providências. Diário Oficial da União, Brasília, DF, 10 jan. 2003.

BRASIL. Ministério da Educação/SECAD/SEPPIR. Diretrizes Curriculares Nacionais para a Educação das Relações Étnico-Raciais e para o Ensino de História e Cultura Afro-Brasileira e Africana.

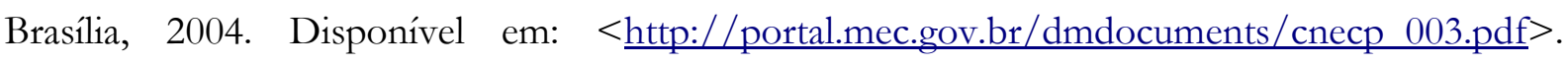
Acesso em: 22 nov. 2018.

CAIMI, Flávia Eloisa. Conversas e Controvérsias: o ensino de história no Brasil (1980-1998). Passo Fundo: UPF, 2001.

CAIMI, Flávia Eloisa. Aprendendo a ser professor de História. Passo Fundo: Editora da Universidade de Passo Fundo, 2008. 306 p.

CHARLOT, Bernard. Da relação com o saber, elementos para uma teoria. Porto Alegre: ARTMED, 2000.

FONSECA, Selva Guimarães. Caminhos da história ensinada. Campinas: Papirus, 1995.

FONSECA, Selva Guimarães. Serprofessor no Brasil: história oral de vida. Campinas: Papirus, 1997.

FREIRE, Paulo. Pedagogia da autonomia. São Paulo: Paz e Terra, 1996.

GOMES, Nilma Lino. Relações étnico-raciais, educação e descolonização dos currículos. Currículo sem Fronteiras, v. 12, n. 1, p. 98-109, jan./abr. 2012. 
GOMES, Nilma Lino. O movimento Negro Educador: saberes construídos nas lutas por emancipação. Petrópolis: Vozes, 2017.

MONTEIRO, Ana Maria. Professores de História: entre saberes e práticas. Rio de Janeiro: Mauadx, 2007.

MONTEIRO, Ana Maria Ferreira da Costa; PENNA, Fernando de Araujo. Ensino de história: saberes em lugar de fronteira. Educação e Realidade, Porto Alegre, v. 36, n. 1, p. 191-211, 2011. Disponível em: <http://seer.ufrgs.br/index.php/educacaoerealidade/article/view/15080>. Acesso em: 18 nov. 2015.

SANTOS, Boaventura de Sousa. Para além do pensamento abissal: das linhas globais a uma ecologia de saberes. In: SANTOS, Boaventura de Sousa; MENESES, Maria Paula. Epistemologias do Sul. São Paulo: Cortez, 2010. p. 23-71.

SILVA, Luiz (CUTI). Literatura negro-brasileira. São Paulo: Selo Negro Edições, 2010.

SILVA, Luiz (CUTI). Contos Escolbidos/Cuti. Rio de janeiro: Malê, 2016.

TARDIFF, Maurice; LESSARD, Claude. O oficio do professor: história, perspectivas e desafios internacionais. Petrópolis, RJ: Editora Vozes, 2011.

WALSH, C. Introducción. Lo pedagógico y lo decolonial: entretejiendo caminhos. In:

Pedagógias decoloniales: prácticas insurgentes de resistir, (re) existir y (re) vivir. Tomo I. Serie Pensamiento Decolonial. Quito, Ecuador, noviembre 2013. p. 23-68.

recebido em 29 set. 2018 / aprovado em 21 nov. 2018

Para referenciar este texto:

MEINERZ, C. B.; GOLEMBIEWSKI, F. A.; OYARZABAL, R. S. Ensino de História, Planejamento e Autoria: experimentações com literatura negra em estágios curriculares obrigatórios. Dialogia, São Paulo, n. 30, p. 59-70, set. /dez. 2018. Disponível em: $<$ https://doi.org/10.5585/Dialogia.n30.10617> 


\title{
Cecília Meireles e sua atuação política na educação brasileira: literatura, jornalismo e feminino
}

\author{
Cecília Meireles and his political action in Brazilian Education: \\ literature, journalism and women
}

\begin{abstract}
Nubea Rodrigues Xavier
Doutora em Educação pelo Programa de Pós-graduação da Faculdade de Educação da Universidade Federal da Grande Dourados. Professora no Centro Estadual de Educação Profissional de Dourados. Mato Grosso do Sul - MS - Brasil nubeaxavier@hotmail.com

Magda Sarat Doutora em Educação pela Universidade Metodista de Piracicaba. Professora associada da Universidade Federal da Grande Dourados. Mato Grosso do Sul - MS - Brasil mcsarat@gmail.com
\end{abstract}

Resumo: O artigo é um recorte de tese de doutoramento e tem como objetivo compreender o contexto educacional brasileiro sob o viés literário e histórico, entre 1930 e 1940, período em que os processos de engajamento social feminino se refletem na figuração educacional e política do país, descrita na produção jornalística e literária de Cecília Meireles. Cecília publicou materiais pedagógicos como cartilhas e livros infantis, escrevendo diariamente no jornal Diário de Notícias, na seção Página de Educação, coluna Comentário, de 1930 a 1933, e posteriormente em 1941. Nossas fontes se pautaram nessas publicações, por ter embates, críticas, discussões e orientações aos educadores em defesa dos direitos da criança. Como resultado, almejamos compreender em que modo a literatura perpassa a produção escrita da autora, e quais as implicações a partir dos equilíbrios de poder existentes na figuração da política educacional brasileira.

Palavras-chave: Escrita literária. Educação. Relações de poder.

Abstract: This paper is a doctoral dissertation cut and aims to understand the Brazilian educational context, under the literary and historical bias,from 1930 to 1940. In this period, the processes of female social engagement are reflected in the educational and political figuration of the country, particularly described in the journalistic and literary production of Cecilia Meireles. This author published pedagogical materials such as booklets and children's books and wrote daily in the Diário de Notícias newspaper in the section Education Page, column Comment, from 1930 to 1933, and later in 1941. Our sources were based on these publications since they present discussions and guidance to educators in the defense of children's rights. As our final result, we aim to understand the ways in which literature has permeated the written production of this author and its implications, starting from the balance of power existing in the figuration of Brazilian educational policy.

Key words: Literary writing. Education. Power relations. 


\section{Introdução}

A autora Cecília Meireles foi educadora, professora universitária, poeta, folclorista, ensaísta, tradutora, escritora e jornalista, produzindo inúmeros editoriais em defesa da educação estética em início do século XX.

Por educação estética compreendemos a aplicabilidade dos valores morais à formação educacional, respeitando as peculiaridades infantis. Esse tipo de valorização, pautava-se numa educação laica e de defesa dos direitos educacionais das crianças, embasadas pelo Manifesto dos Pioneiros, consoantes aos ideais da Escola Nova.

Cecília Meireles, conforme matérias escritas para a coluna Educação, do jornal Diário de Notícias, da cidade do Rio de Janeiro - no período de 1930 a 1933, e em1941 ${ }^{\mathrm{i}}$-, buscava romper com a ideia de padronização de ensino que existia na escola. Ela fazia uma abordagem cientificista, amparada pela sua rede de amigos pensadores, escritores e filósofos, e preocupava-se com a relação existente entre a criança, a família e a escola. A partir dessa perspectiva, Cecília defendia uma escola laica, gratuita e se opunha às decisões do ministro da educação Francisco Campos e do Governo Getúlio Vargasii , concretizando embates e disputas de poder, empreendidos principalmente pela sua produção jornalística e poética.

Respaldando a educação estética dessa autora, tivemos o Manifesto dos Pioneiros que foi um documento elaborado por 26 signatários - educadores, intelectuais, médicos, escritores, técnicos educacionais, artistas -,com destaque para Cecília Meireles, Monteiro Lobato, Anísio Teixeira, Fernando de Azevedo e Mário de Andrade ${ }^{\mathrm{iii}}$ que almejavam a elaboração de diretrizes e sistematização da educação brasileira. Tratava-se de uma busca, de uma revolução da educação, com ideias que disseminassem uma reestruturação das práticas pedagógicas e de infraestrutura escolar, valorizando a autoformação e a atividade espontânea da criança. A Escola Nova apresentou-se como um movimento de educadores e intelectuais que se pautavam nos pressupostos teóricos de John Dewey, opondo-se à escola tradicional, abarcando uma abordagem cientificista legitimada naquele momento histórico.

Assim, a produção escrita sobre a educação daquele período busca elencar como Cecília Meireles descrevia a criança das primeiras décadas do século XX, dispondo suas convicções e perspectivas para os modos de ser criança e destacando como a literatura completava sua escrita. O objetivo desta pesquisa é identificar, na escrita desta escritora e poeta, como a literatura desencadeou uma função social e política na atuação educadora de Cecília Meireles e quais equilíbrios de poder foram possíveis ao colocá-la como engajada ou distanciada em relação às figurações sociais da educação brasileira. Para averiguação desses 
pressupostos, nos pautaremos no material bibliográfico produzido por suas publicações jornalísticas no Diário de Notícias, no período de 1930 a 1933 e nas teorias sociológicas de Norbert Elias.

A pesquisa justifica-se por compreendermos que a formação profissional e literária da educadora Cecília Meireles incidiu em ideais educacionais para crianças. Por figuração relacional de poder entendemos que os indivíduos, ao fazer parte de redes sociais e com elas interagir, aprendem, ensinam, hostilizam e tomam decisões. Tais atitudes não são neutras, mas instituídas por interesses na relação de poder, pois cada ação interfere na vida privada e pública dos indivíduos determinando comportamentos, desejos, posturas e costumes. Assim nos apontou Elias (2011; 2003; 2000; 1980), ao buscar compreender como o indivíduo, em determinados períodos da história, "situa-se nas cadeias sociais de interdependência dos acontecimentos relativos exclusivamente a tais períodos na história” (LEÃO, 2007, p. 29), dispondo o processo histórico como dinâmico e repleto de tensões e conflitos.

Almejamos compreender como a escrita literária dessa autora se impôs perante os embates educacionais, e como as relações de poder se configuraram na formação da escola brasileira no início do século XX.

\section{As figurações sociais e a literatura na vida de Cecília Meireles}

Cecília Meireles teve a literatura como sua forma de se enxergar no mundo. "Eu canto porque o instante existe e a minha vida está completa. Não sou alegre nem sou triste: sou poeta...”

Sua autobiografia Olbinhos de gato, publicada inicialmente como editorial numa revista portuguesa, no ano de 1939, e posteriormente editada como livro na década de 1980, retrata, desde 1901, ano de seu nascimento, uma infância solitária, introspectiva, cheia de angústias e tristezas, em meio a um sentimento de pequenez pelo qual ela se enxergava: "Olhinhos de gato perde a vontade de ouvir, e - vai andando pra longe, com seus cacos e seus pedaços de concha!" (MEIRELES, 1983, p. 19).

Desde muito pequena, Cecília destacou-se na arte de escrever. Aos nove anos recebe das mãos de Olavo Bilac, "sua primeira medalha de mérito pelos versos escritos" (YUNES; BINGEMER, 2003, p. 115). Foi aluna exemplar, concluindo o curso primário em 1910.

$\mathrm{Na}$ fase da adolescência, formou-se como professora na Escola Normal Superior, "aos dezesseis anos já é mestra alfabetizadora e estuda línguas, cultura oriental e canto, 
enquanto escreve seu primeiro livro de poesias Espectro, editado em 1919" (YUNES; BINGEMER, 2003, p. 115, 116).

Cecília amparava-se nessas instruções enquanto defensora da Escola Nova. Desde então já promovia discursos e saberes que envolviam essa temática e as infâncias.

Enquanto jornalista, trazia à tona a escolha inadequada dos representantes escolhidos para avaliação, pela forma como estes faziam suas análises em uma única perspectiva, abordando critério humanístico religioso, desconsiderando o científico e filosófico. Uma sua faceta pouco estudada e explorada pela crítica é a de cronista, em que opina, dialoga, critica e se posiciona politicamente em relação à ditadura de 1930 a 1933, insurgindo-se contra um populismo autoritário e defendendo uma escola nova para a constituição de uma república efetivamente democrática.

Em 1934, Cecília funda, no Rio de Janeiro, com a ajuda de Anísio Teixeira, a primeira biblioteca infantil, intitulada Centro Infantil no Pavilhão Mourisco, demonstrando seu profundo interesse pelas temáticas que envolviam o aprendizado das crianças. No entanto, "graças às perseguições políticas, o espaço foi fechado por Getúlio Vargas. Como justificativa, alegou-se que a biblioteca possuía obras que atrapalhavam a formação das crianças" (SILVA, 2015, p. 14). A suspeita era de que Cecília tinha livros comunistas.

No ano seguinte, a Academia Brasileira de Letras lança um concurso de poesia, e Cecília, com o seu livro Viagem, venceu o concurso sobrepondo-se aos demais 29 livros avaliados. Segundo um dos avaliadores, Cassiano Ricardo, Cecília, “desloca o julgamento para um plano tão alto que os demais concorrentes só puderam ser considerados pelo contraste, e não pelo confronto" (LÔBO, 2011, p. 63). Todavia, novamente, a poeta e autora passa por impasses sobre sua produção.

Além desse fato inoportuno, Cecília não pôde realizar seu discurso de oradora, tal como gostaria, porque havia uma "censura acadêmica". Inicialmente, ela se dispôs a adequar seu discurso, porém, ao perceber que se tratava de algo além dos preâmbulos políticos, declina de fazê-lo.

Cecília e seus amigos intelectuais acreditavam que a Revolução de 1930 traria uma nova política educacional. No entanto, eles tiveram uma grande decepção com esse novo regime político, sob o governo de Getúlio Vargas, ao ver a nomeação de Francisco Campos para o Ministério da Educação e Saúde implantar ações retrógradas, dentre elas, o ensino religioso escolar. Mesmo diante dessa circunstância, Cecília e esses intelectuais se fortaleciam formando uma rede de relações, em que ela, mais do que todos, sustentava ideias inovadoras para a educação - o escolanovismo. A escritora, por meio da literatura, valorizava os 
conhecimentos das crianças, percebendo-as como sujeitos sociais. Nessa perspectiva, suas crônicas jornalísticas apresentavam conotação política e social.

A partir das suas publicações jornalísticas, consideramos que Cecília subverteu as normas de seu tempo, ao se colocar de maneira incisiva e resistente ao contexto de dura repressão, equilibrando-se com as estratégias de poder do governo, já que a consolidação desse poder se fazia com uma forte construção ideológica sobre nacionalidade, e com a identidade brasileira, ancoradas em teorias de segregação racial.

Dessa maneira, Cecília colocava-se à altura das exigências do respeito intelectual, ao demonstrar sua produção em um material extenso e aprofundado sobre suas idealizações de educadora e mulher.

\section{A escrita literária e jornalística de Cecília Meireles: as relações de poder no cenário político educacional}

Cecília Meireles foi uma defensora da infância e da coeducação $o^{\text {iv }}$. Concomitantemente à sua atuação literária enquanto escritora, poeta e artista, escreveu matérias também como educadora e professora universitária, diariamente - no período de 12 de junho de 1930 a 12 de janeiro de 1933 -, na coluna Comentário, seção Página de Educação, do Diário de Notícias.

Sua produção escrita não desvincula-se do estilo literário: suas crônicas jornalísticas traziam em seu bojo a valorização da literatura como possibilidade de interpretação da realidade, para que se percebesse a criança como protagonista social, tendo seu conhecimento respeitado, não pela perspectiva do adulto, mas pela ótica do seu tempo de infância. Assim, considerava que a educação poderia ter uma função política, percebendo as diferenças e respeitando as diversas identidades da infância, independentemente da classe social ou da religião.

Por conta disso, Cecília teve sua trajetória de professora marcada por represálias e imposições relacionados ao seu exercício profissional, por colocar sua perspectiva poética e artística em sua compreensão de mundo e de educadora. Dona de vasto conhecimento, ela transitava entre intelectuais, poetas, escritores, artistas e burocratas educacionais. Acreditava que a educação deveria ter uma diretriz e sistematização, e concretizava tal compreensão a partir de suas publicações nos jornais esclarecendo e ampliando as discussões e ações sobre a temática. Seus pressupostos educacionais acabaram por se contrapor ao governo Getúlio Vargas. 
A periodista e educadora, por sua vez, não deixou de se colocar frente a esses acontecimentos. Inicialmente, com as propostas da Revolução de 1930, se pôs a favor desses ideais "a Revolução, que neste momento acaba de transformar o Brasil numa formidável esperança para o mundo inteiro, traz no programa grandes nomes que a encaram, todas as características de um movimento significativamente educativo” (MEIRELES, 2001, v. 2, p. 120). Dessa forma, essa notícia foi remetendo outras com temáticas tais como: "As crianças e a revolução"; "Educação e revolução"; "Política e pedagogia"; "Educação artística e nacionalizadora"; "O momento educacional"; "A responsabilidade da revolução", entre outras (LÔBO, 2011, p. 33).

Sucessivamente, com as decisões do então ministro da educação, Francisco Campos, ao colocar-se a favor dos conservadores, a jornalista rebelou-se e fez da sua coluna uma estratégia de oposição ao governo Vargas. Uma delas foi colocar-se a respeito da aprovação do "Decreto $\mathrm{n}^{\circ}$. 19.941, de 30 de abril de 1931, que instituía o ensino religioso nas escolas públicas", acabando por tecer duras críticas, expondo a necessidade de se respeitar o princípio de laicidade do ensino imputado pelos educadores da Escola Nova.

Para a educadora, a escola deveria respeitar todas as outras formas de crendices e religiões, principalmente por se tratar da instrução e formação da criança. Não aceitava que a religião estivesse acima do cientificismo.

Em janeiro de 1933, por pressões políticas, a jornalista deixou de realizar suas publicações "por desencanto e por cansaço diante do conservadorismo sempre em oposição às ideias renovadoras" (AZEVEDO FILHO, 2001, p. 18), pois o jornal também sofreu perseguições políticas e Cecília cessou de escrever em 1933, retomando essa atividade somente em 1941. Com essas perseguições políticas, volta-se a outras frentes de trabalho. Esse tipo de repreensão demonstrava o quanto a oposição de Cecília, com suas publicações, surtia efeitos contrários ao que os reformadores educacionais defendiam como mudança social. Cecília, antes da ascensão de poder de Vargas, acreditava nos ideias de transformação da educação, bem como nas propostas sugeridas por Fernando de Azevedo. Todavia, quando Vargas se coloca a favor dos interesses da Igreja e inicia um governo autoritário, e Francisco Campos (Ministro da Educação) se pauta em adequar as reformas, voltando-se a uma perspectiva científica e de construção de edifícios escolares- e não às necessidades dos alunos, professores e família -, ela se coloca em oposição a esses procedimentos utilizando como armamento social, seu intelecto.

Nessas relações de poder, ocorre, em 1932, o lançamento do Manifesto dos Pioneiros, tornando a escrita de Cecília ainda mais inserida num limiar entre suas defesas educacionais 
e os conflitos políticos, o que a tornou uma jornalista incompreendida em seu tempo: "sua trajetória permeava as linhas demarcatórias do espaço social, trilhando caminho não convencional, sem se enquadrar nos cânones da cultura oficial. Desse modo, foi motivo de indiferença, de resistência e de perseguição" (RAMANZINI, 2014, p. 77-78). Suas matérias enfatizavam a valorização e utilização do folclore e da tradição popular como temáticas relevantes ao aprendizado da criança, e defendiam uma nova metodologia educacional, valorizando a sensibilidade e a inspiração infantil.

Azevedo Filho, organizador das publicações jornalísticas de Cecília, afirma que a autora impunha críticas à educação de maneira contundente, com preocupação com a formação da criança “[...] a partir do respeito à personalidade do aluno, em todas as fases de formação e em todas as idades do seu crescimento e desenvolvimento" (AZEVEDO FILHO, 2001, v.1, p. 17).

Em meio às pressões e imposições políticas, em 1936, Cecília Meireles vai para Portugal. Lá, seu amigo Álvaro Pinto, proprietário da Revista Ocidente, solicita que ela publique seus poemas e suas memórias de infância que, posteriormente, seriam editadas no Brasil, como Olbinhos de gato.

Em 1941, a autora retomou suas publicações na Página da Educação do jornal $A$ Manhã, reiterando na seção Professores e Estudantes, a valorização dos professores e do folclore infantil nas aulas práticas, além de defender as reformas educacionais.

No ano de 1946, tem-se o fim da ditadura Vargas, a sociedade inicia uma mobilização em busca de um desenvolvimento em várias áreas. Com esse novo contexto político, tanto a educação quanto os interesses voltados à emancipação feminina alcançam novas aberturas sociais.

No final da década de 1940, Cecília profere "três conferências em Belo Horizonte, no curso de férias promovidas pela Secretaria de Educação” (MEIRELES, 2016, p. 9) sobre literatura infantil, resultando na publicação do livro Problemas da literatura infantil, em 1951, obra que orientava como e o que escrever para criança, para que educadores soubessem utilizar corretamente os conhecimentos aplicados à valorização da criança.

Cecília, em 1951, aposenta-se como diretora de escola, mas continua trabalhando no Rio de Janeiro como produtora e redatora de programas culturais, na Rádio Ministério da Educação. Sua preocupação, durante todos esses anos, só aumentava em relação aos rumos da educação das crianças. Em 1953, lança o Romanceiro da Inconfidência que:

[...] reescreve o episódio da insurreição da província mineira que custou a vida de mártires da pátria no século XVIII, Cecília recompõe a cena, os bastidores e o palco do evento com invejável domínio de fatos e das 
imagens com que o projeta na literatura. (YUNES; BINGEMER, 2003, p. 119).

Durante a elaboração dessa obra, fez uma "investigação, revirando, ao longo de meses e meses, documentos que iam da filosofia a política, com leituras de Rousseau, Voltaire, Montesquieu, entre dezena de outros" (GOUVÊA, 2008, p. 97). Além dessa obra, também publica Batuque, Poemas escritos na Índia, Poemas italianos- todos em 1953; Pequeno Oratório de Santa Clara, Pistóia, Cemitério Militar Brasileiro e Panorama Folclórico de Açores, no ano de 1955; Canções, Giroflê, Giroflá e Romance de Santa Cecília, no ano de 1956.

Uma das últimas publicações em vida foi em 1964, ano de sua morte, a obra Escolha o seu sonbo e o livro de poesias $O u$ isto ou aquilo com temáticas exclusivas ao público infantil, dentre eles os poemas "O menino azul" e "Os pescadores e suas filhas".

Pontuamos que não foi somente na literatura que Cecília se desnudou para mostrar seus sentimentos, angústias, emoções; sua escrita jornalística também trazia a literatura como essência, concretizando seus desejos e intenções para a formação estética da criança "e, afinal o sentido da educação é o de prover o homem das forças que lhe sejam necessárias para essa realização de si mesmo" (MEIRELES, 2001, v. 4, p. 68); defendeu práticas, teorias e posturas que imbicassem uma maior aproximação ao mundo infantil. Essas abordagens em defesa da educação e da criança atingiam tanto os burocratas educacionais, como as educadoras, os inspetores, os dirigentes escolares, a igreja e as famílias.

Ao dispor dados biográficos sobre a vida pessoal, profissional e acadêmica dessa autora, queremos demonstrar o quanto sua atuação de escritora, poeta e artista perpassaram as demais figurações aos quais ela esteve envolvida. Seus princípios e percepção poética não deixaram de transparecer em sua inserção política educadora, o que a colocou em momentos de engajamento ou distanciamento social sobre os fatos políticos e sociais, demonstrando o quanto sua escrita foi preponderante para defender seus ideias e princípios sobre a criança e a menina no início do século XX.

\section{Algumas considerações à guisa de conclusão}

Verificamos que Cecília Meireles se ampara na idealização de uma voz própria para conseguir se expressar e delimitar sua posição enquanto mulher e educadora, no seu contexto social e histórico, como nos demonstram os equilíbrios de poder que ela vivenciou durante sua trajetória pessoal e profissional. 
Mediante o exposto, queremos atentar que sendo ela mulher, poeta e jornalista, sua postura enquanto educadora se desenrolava em espaços de poder, em uma linha de oposição aos órgãos governamentais e diretamente com o secretário de educação.

Nesses termos, as figurações sociais foram determinadas pela participação e vinculação da mulher, independentemente de ser mulher ou de sua escrita feminina, com Cecília tendo função importante dentro do Manifesto dos Pioneiros e da proposta da Escola Nova. Ela oferecia tanta imposição aos órgãos educacionais, que em 1933 sua coluna deixou de ser publicada.

Assinalamos que, no jornal, Cecília traçava diálogos com os educadores, intelectuais e a comunidade leitora, fazendo denúncias, críticas, além de posicionar-se contrária às decisões políticas e educacionais da época em relação à mulher e à criança.

Cecília buscava promover entre os educadores a compreensão de uma educação estética, onde a literatura possibilitasse a significação, além da escola, em transcender as práticas mecânicas de saber ler, escrever e contar "a preocupação de instruir, que até bem pouco dominava a de educar, a ansiedade dos pais também mal orientados, querendo a todo o transe que os filhos soubessem ler e escrever.” (MEIRELES, 2001, v.4, p. 25).

Seguindo as perspectivas eliasianas, queremos pontuar que a autora conseguia transitar em espaço, majoritariamente masculino, em meio a pensadores, burocratas e políticos, colocando-se como estabelecida. Se em determinado período, a jornalista ficou impossibilitada de publicar suas matérias, entre 1941 e 1943 teve novamente condições de continuar com suas críticas, desta vez no jornal $A$ Manhã - seção Professores e Estudantes - pontuando sobre a valorização dos professores, sobre folclore infantil, além das defesas quanto às mudanças educacionais. Para ela, a implantação da Reforma Fernando de Azevedo, apesar das inúmeras imperfeições, conseguiu "estimular as forças vividas do magistério; trouxe uma esperança nobre para os que se iam finando, desiludidos, na sombra do regime antigo.” (MEIRELES, 2001, v. 2, p. 111).

A atuação da autora, enquanto mulher, não se coloca como menor ou sem significância nas redes de interdependência social ao qual estava vinculada. Sua produção jornalística como estabelecida $a^{v}$ nos indica que, em dado contexto sócio-político, Cecília pôde sentir-se inserida, obtendo resultados com suas reivindicações. Porém, em outro, foi colocada de maneira distanciada, isolada, como foi o caso de quando a pressionaram para que parasse de publicar suas matérias no jornal ou quando fecharam a biblioteca infantil pela qual era responsável. Para Elias (2000), a sociedade não é elaborada somente por uma hierarquização de gênero, em que o masculino se sobrepõe ao feminino: as relações entre 
homens e mulheres se concretizam também por estruturas de poder, que se equilibram numa balança relacional de poder.

Como educadora, Cecília Meireles almejava um espaço social para a criança, como aquele pertencente a direitos, e respeitado a partir de suas peculiaridades. E mais: atuava enquanto escritora, jornalista e poeta perpetuando seus ideais em meio às redes de interdependência, trazendo à tona as sujeitas femininas das diversas infâncias de sua autobiografia, como também daquelas de suas matérias jornalísticas que atuavam com a educação e instrução das crianças.

As publicações no Diário de Notícias deixavam nítidas as inúmeras figurações das quais Cecília Meireles participava e atuava enquanto educadora e mulher, alcançando um patamar de equilíbrio com homens. Sua escrita composta por ímpeto e indignação em relação às ações governamentais daquele período, demonstrava os embates e disputas sobre os encaminhamentos para a educação de crianças.

Cecília teve em seus escritos sobre educação muita desenvoltura, não somente pela experiência como professora de criança, mas também por expor as mazelas e deficiências escolares, escrevendo sobre as lacunas entre os interesses das crianças e a realidade pedagógica concreta, sobre as práticas ou métodos incoerentes dos professores e sobre a necessidade de valorização da infância.

Ela argumentava de modo perspicaz e fundamentado sobre a criança, não como o adulto a compreendia, mas sobre a criança como sujeito social, dentro de uma percepção educadora. Como jornalista, suas inúmeras colunas no Diário de Notícias expressam a situação nas escolas, não atenuando as problemáticas que envolviam a atuação de professores, dos dirigentes, dos secretários educacionais, dos prédios escolares, dos pais ou responsáveis, e dessa forma escrevia sobre suas inquietações, apontava instruções, orientações e tecia críticas que eram lidas por mães, pais, educadores, crianças e responsáveis políticos.

Nesse campo jornalístico, Cecília tentou reaver as compilações da professora primária que a incentivou a estudar o folclore brasileiro, as considerações poéticas e literárias de seu educador Olavo Bilac, colocando suas impressões da formação de aluna e normalista como pontos cruciais na sua produção feminina e intelectual. Almejava e conduzia sua carreira poética, literária e jornalística sem desvencilhar-se de sua individualidade e liberdade para se colocar como difusora de novas posturas e comportamentos.

Publicando e escrevendo, Cecília traçou propostas, projetos e interveio no campo educacional brasileiro. Mesmo sem considerar-se feminista, escrevia e defendia a qualificação, a valorização, a instrução, a formação e a independência da mulher. Sem 
colocar-se religiosa, escrevia e defendia uma proposta ecumênica de fraternidade e amor universal. E na educação, sua pauta era liberdade, respeito, ludicidade e cientificidade.

Cecília Meireles foi transgressora, singular e determinada em sua atuação: elaborou uma infinidade de crônicas, livros, materiais didáticos, artísticos, poéticos, educacionais, e ainda uma produção jornalística, editada diariamente, entre 1930 e 1933, quando foi editora chefe.

$\mathrm{Na}$ teia configuracional que estava inserida, suas produções a faziam oscilar entre estar em evidência ou ser silenciada. Intelectuais, jornalistas, artistas, escritores, editores de revistas no Brasil e outros países como Portugal, Estados Unidos, Chile ou Índia, além de vários outros da América Latina, viam-na como uma personagem forte e indispensável para a literatura e educação tanto brasileira como estrangeira - tal situação foi demonstrada em palestras realizadas em Portugal nos anos 1930.

Nas figurações educacionais, podemos inferir que as redes de interdependência, às quais esteve vinculada, sua escrita literária e sua individualização auxiliaram-na colocar-se como estabelecida em certos momentos políticos.

Cecília teve em seus escritos sobre educação muita desenvoltura, não somente pela experiência como professora de criança, mas por expor as mazelas e deficiências escolares: apontava as lacunas entre os interesses das crianças e a realidade pedagógica concreta, escrevendo sobre as práticas ou métodos incoerentes dos professores e pontuando a necessidade de valorização da infância e não daquilo que o adulto compreendia como infantil.

Podemos dizer que foi uma escritora de várias facetas, todas elas sem desvincular-se da sua estética poética, dispondo-a nos modos de compreender a criança e a sua educação, propondo a compreensão das artes e da literatura como proposta de formação para a vida.

\section{Referências}

AZEVEDO FILHO, Leodegário. A. Prefácio. In: Cecília Meireles: crônicas da educação. Rio de Janeiro: Nova Fronteira: Fundação Biblioteca Nacional, v. I, II, III, IV, 2001.

ELIAS, Norbert. Introdução à sociologia. Lisboa: Edições 70, 1980.

- A sociedade dos indivíduos. Rio de Janeiro: Jorge Zahar: 2003.

. O processo civilizador: uma história dos costumes. v. 1. Rio de Janeiro: Zahar, 2011. 
SCOTSON, John L. Os estabelecidos e outsiders: sociologia das relações de poder a partir de uma pequena comunidade. Rio de Janeiro: Jorge Zahar, 2000.

FELGUEIRAS, Margarida. A escola pública em Portugal (Séc. XVIII-XX): problemas em debate. In: LOMBARDI, José C.; SAVIANI, Demerval; NASCIMENTO, Maria Isabel Moura (Org.). A escola pública no Brasil: história e historiografia. São Paulo: Autores Associados, 2005, p. 109-141.

GOUVÊA, Leila Vilas Boas. Pensamento e "lirismo puro" na poesia de Cecília Meireles. São Paulo: Edusp, 2008.

LEÃO, Andrea Borges. Norbert Elias e a educação. Belo Horizonte: Autêntica, 2007.

LÔBO, Yolanda. Cecilia Meireles. Recife: Fundação Joaquim Nabuco, Massangana, 2011.

MEIRELES, Cecília. Viagem. Rio de Janeiro: José Aguilar, 1967. Olbinhos de gato. São Paulo: Moderna, 1983.

Cecília Meireles: crônicas da educação. Rio de Janeiro: Nova Fronteira: Fundação Biblioteca Nacional, vol. I, II,III, IV , 2001. Problemas da literatura infantil. 4. ed. São Paulo: Global, 2016.

RAMANZINI, Isis Cristina. Paratopia criadora: Cecília Meireles, uma escritora atuante no cenário educacional. Revista L@el em (Dis-)curso.v. 6, n. 2, p. 72-83, 2014.

SILVA, Roberta Donega. Serenas e desesperadas: representações femininas na obra poética de Cecília Meireles. 2015. 117 f. Dissertação (Mestrado em Letras) - Faculdade de Ciências e Letras de Assis, Universidade Estadual Paulista Júlio de Mesquita Filholl, Assis, 2015.

YUNES, Eliana Lucia Madureira; BINGEMER, Maria Clara Lucchetti. Adélia Prado, Hannah Arendt, Cecília Meireles, Teresa Avila e Simone Weil: mulheres de palavra. São Paulo:Loyola, 2003. 


\section{Notas:}

${ }^{i}$ Essas produções jornalísticas foram compiladas em Crônicas de educação, organizada em quatro volumes por Leodegário A. de Azevedo Filho.

iiFrancisco Campos realizou uma reforma educacional que defendia a aplicação do ensino religioso nas escolas públicas. Tal ação fez com que Cecília Meireles tecesse duras críticas à sua atuação.

iiiMonteiro Lobato - escritor e editor brasileiro de obras infantis, dentre elas, O Sítio do Pica-pau Amarelo. Anísio Teixeira - educador brasileiro que implantou, nas décadas de 1920 e 1930, um novo modelo e formato de educação pública e gratuita no Brasil (difundido pelos pressupostos de John Dewey),foi educador, ensaísta, sociológico, professor e diretor universitário da Faculdade de Filosofia, Ciências e Letras da Universidade de São Paulo (USP), reformador da instrução pública do Distrito Federal, entre os anos de 1927 e 1930. Mário de Andrade - escritor brasileiro que exerceu importante papel na consolidação do Movimento Modernista no Brasil.

iv Coeducação seria o educar em conjunto meninos e meninas. Nesse período, as meninas não tinham assegurado seu direito de ir à escola, e este seria um dos requisitos do Manifesto dos Pioneiros. Segundo Felgueiras, a educação das meninas deveria prepará-las para melhor desempenhar as tarefas domésticas e do governo da casa, para ser as primeiras educadoras dos filhos e companhias agradáveis para os maridos. Esta educação, nas famílias de estrato social alto, estava tradicionalmente a cargo das preceptoras; nas de estrato mais baixo, com as mães ou em casas de terceiros, onde muito cedo iam trabalhar. Educação era assunto reservado às mulheres, onde apenas interferiam as orientações religiosas e, posteriormente, as médicas (FELGUEIRAS, 2005, p. 124).

vNorbert Elias (2000), no estudo Os estabelecidos e outsiders, colocou como ponto central o tempo e as relações de poder numa comunidade. A análise feita pelo autor supera as dicotomias do pensamento sociológico na formação da sociedade humana. Ao designar um grupo como outsiders, descreve que se trata de indivíduos excluídos e percebidos como inferiores dentro do seu próprio grupo - por não serem observantes das normas e regras sociais impostas. Os estabelecidos são aqueles que mantêm superioridade social e excluem os demais dentro de um mesmo grupo social.

recebido em 05 out. 2018 / aprovado em 21 nov. 2018

Para referenciar este texto:

XAVIER, N. R.; SARAT, M. Cecília Meireles e sua atuação política na educação brasileira: Literatura, Jornalismo e Feminino. Dialogia, São Paulo, n. 30, p. 71-83, set. /dez. 2018. Disponível em: <https://doi.org/10.5585/Dialogia.n30.10669> 
ARTIGOS 


\title{
Infusing an international online learning experience into the curriculum: a United States and Mexico collaboration
}

\author{
Infundindo uma experiência de aprendizagem internacional online no \\ currículo: uma colaboração entre Estados Unidos e México
}

\begin{abstract}
Flavia Iuspa
Received her Ed.D. in Curriculum and Instruction with specialization in International and Intercultural Education from Florida International University. Instructor an Director of the Master of Science in Curriculum and Instruction (MSCI). Florida - EUA

iuspaf@,fiu.edu
\end{abstract}

\begin{abstract}
Globally competent people have the knowledge, skills, and dispositions to understand and to find lasting solutions to global issues and problems using multiples perspectives. They understand interdependence and interconnectedness of the global systems, cultures and communicate effectively with different people around the world. The purpose of this paper is to discuss how an international online learning experience enhances our awareness of different perspectives and cultural diversity, the challenges facing humanity and the world, and our role as globally competent citizens. In particular, this paper discusses the design and implementation of an international online learning experience to promote global learning between two higher education students in the United States and Mexico. The paper uses global competency as the pedagogical framework for teaching and promoting global learning within the context of global competency.

Key Words: Global Competence. Global Learning. Online Learning. Multicultural Online Collaboration. International Cooperation in Higher Education. Cross-Border Delivery of Education.
\end{abstract}

Resumo: Pessoas globalmente competentes têm o conhecimento, as habilidades e as disposições para entender e encontrar soluções duradouras para problemas e problemas globais usando perspectivas múltiplas. Elas entendem a interdependência e interconexão dos sistemas globais, culturas e se comunicam efetivamente com pessoas diferentes em todo o mundo. O objetivo deste artigo é discutir como uma experiência internacional de aprendizado online aumenta nossa consciência sobre as diferentes perspectivas e diversidade cultural, os desafios que a humanidade e o mundo enfrentam e nosso papel como cidadãos globalmente competentes. Em particular, este artigo discute a elaboração e implementação de uma experiência de aprendizado online internacional para promover a aprendizagem global entre estudantes do ensino superior nos Estados Unidos e no México. O artigo considera a competência global como estrutura pedagógica para ensinar e promover a aprendizagem global dentro do contexto da competência global.

Palavras-chave: Competência Global. Aprendizagem Global. Aprendizagem Online. Colaboração Multicultural Online. Cooperação Internacional em Educação Superior. Difusão Transfronteiriça de Educação. 


\section{Introduction}

Global education seen as a curriculum provides the content and strategies for global learning. Global knowledge, skills and understanding are needed to engage people especially young learners in the effort to make the world a better place. Collaborative online learning is becoming a legitimate way of teaching global learning. As the global community becomes more open and transparent and racial, ethnic, cultural, economic and political conflicts escalate around the world, there is a need to find a modality for global expression.

The deepening global diversity within nations highlights the world's complexity and interdependence among nations. At the same time, a current backlash against globalization and the rise of nationalism, more than ever presents to higher education institutions the need to provide to students the ability to engage in meaningful engagement experiences with other cultures and perspectives. Global learning, defined as the process of diverse people collaboratively analyzing and addressing complex problems that transcend borders (LANDORF; DOSCHER, 2015), embodies international collaboration and engagement to address global challenges.

Global Learning promotes critical and reflective discourse and the engagement of simple and complex dialogue, which often leads to practical and structural action at the local, national, regional, and global levels (ABDULLAHI, 2010). Pike and Selby (1995) proposed four-dimensional model of global learning: spatial, issues, temporal, and inner dimensions. In the spatial dimension, concepts such as interdependence and interconnectedness at multiple levels including intrapersonal, interpersonal, international, regional and local issues and problems are explored. In the issues dimension, the focus is on key global issues, problems, and themes. In the temporal dimension, the focus on giving the future the central place in the educational discourse and process. In the inner dimension, the examination and reexamination of self and relationship with others are explored within the context of selfidentity, self-knowledge and self-discovery (ABDULLAHI, 2010). Collaborative online learning offers the opportunity to students in different countries and cultures to learn quickly about issues and problems impacting people and endangering the planet. The purpose of this paper is to discuss the implementation of international online learning experience between an American and Mexican universities to enhance cross-cultural awareness; a key disposition for global learning. The paper uses global competency as the pedagogical framework for teaching and promoting global learning. The purpose guided the paper research question: How does an international online learning experience enhances global competences? 


\section{International Online Learning and Global Competence}

Many universities and colleges in the United States and around the world are developing centers and institutes to provide a platform for engagement, activism, advocacy, partnerships, and international collaboration. The international online learning experience provides a more intensive, friendly, and innovative environment to design a curricular internationalization effort through the use of online technology. International online experience "encourages and supports the development and implementation of collaborative online international courses as a format for experiential cross-cultural learning" (SUNY, Guide for Course Development, 2017, p. 1). It seeks to build bridges between study abroad, instructional design, and teachers through team-taught courses, and in the process, it promotes, integrates, and enhances international, intercultural education, (global education, education for global citizenship) experiences across curricula (SUNY, Guide for Course Development, 2017, p. 1)

Consensus has been reached today about the need for students to develop global competency to face the challenges facing the 21st century (Partnership for 21st Century Learning, 2014; OECD, 2016). Global competence is defined as a disposition, "a way of thinking and doing and as a value" (REIMERS et. al., 2016, p. xxxii). Global Competence promotes a lifelong learning and inquiry based attitude, directed to not only promoting the understanding of the local and global issues relationship, but also to engaging students in working to find solutions to global challenges. Having a global competence, thus, embraces a disposition to inquire about the world (for example, engaging with questions of significance, exploring local-global connections, and seeking information beyond familiar environments). Boix-Mansilla (2016) described three dispositions global thinkers should have:

1) A disposition to understand multiple perspectives—others' and their own.

2) A disposition toward respectful dialogue (communicating across difference appropriately, listening generously, and sharing courageously).

3) A disposition toward taking responsible action (being inclined to see and frame opportunities to improve conditions, collaborating with others, and mobilizing themselves to act) (p. 13).

The international online experience, as a content and a global pedagogical framework, promotes cross/multicultural understanding between students in different countries through online collaboration. In the context of online collaboration, Law and 
NguyenNgoc (2010) discussed three dimensions: social, cognitive and affective. These dimensions are designed to influence the quality of cross-cultural interaction. It is important to recognize that these dimensions are not only aligned with the dispositions of global competence, but are also embedded in what the international online experience concept represents. The international online experience framework enhances students' social (crosscultural communication interaction), the cognitive (through the analysis of content area through different lenses), and the affective (through self-reflection and online discussion cross-culturally) fostering a holistic disposition toward global thinking and competence. Furthermore, it exemplifies a pedagogy for a global learning and the internationalization of the curriculum (ALTBACH; KNIGHT, 2007; IUSPA, 2014).

\section{International online experience Pre and Instructional Planning}

The international online experience was infused into the cross-listed courses Developing a Global Perspective (SSE 4380 and SSE 5381) offered at an university in south Florida, United States and an undergraduate course (INR 4XXX) at Universidad de Chihuahua, México, as part of their pedagogical international activities.

The involvement with the international online experience started during the summer term of 2016, when the American university was invited to participate in the US-Mexico Multistate international online experience Program (MCP). The program was an eye opener and rich in global content and curricular design. The goal of the program was to "increase inter-university collaboration between Mexican and US academic institutions through international online experience-enhanced courses that link students, professors, and staff, contributing to greater intercultural understanding and cross-border dialogue" (SUNY Website, para. 1). The professional development program provided a 180 hours of professional development. This online program offered in four phases (as well as a workshop in Mexico), led the participants from a gradual learning path of what international online experience is, to the matching and selection of universities partners between the US and Mexico, and more course specific international online experience planning and development between the US and Mexico partners.

The university partner in Mexico was a public higher education institution. From the start, the instructors developed a close working relationship and were committed to the design of a rewarding international online experience for our students. After several online meetings, discussions, and reflections on how to infuse and harmonize an international 
online experience for our respective students, the instructors decided to focus on the student learning outcome (SLO): Students will develop awareness of US and Mexico perspectives on global issues. The instructors collaboratively selected the content from a variety of articles related to the following global issues: Population Trends in the 21st Century, Climate Change, and Terrorism. The instructors decided to select these topics given the similarity in content in both courses.

After the pre-instructional planning, the instructors engaged in the instructional planning of the international online experience. The seven weeks' modules were developed and delivered through the Learning Management System (LMS) schoology. Schoology allowed students and professors from both universities to have access to a content without being restricted by the respective universities' student access to blackboard or moodle. The instructors worked together on the international online experience modules' set up (incorporating resources and activities instructions) as well as instructors' introduction video.

\section{International online experience Strategies and Activities}

The international online experience was offered to the respective US and Mexico students during the Spring 2017. The international online experience was 7 weeks long during which students were engaged in the cross-cultural analysis and discussion of global issues. The rationale for the international online experience cross-cultural online activities was that they "must provide opportunities for dynamic and reciprocal communication, interactions, and collaborations that facilitate knowledge co-construction" (CHEN; CAROPRESO; HSU; YANG, 2012, p. 25) among the students. The activities were developed in relations to the three dispositions of developing global competency: 1) recognition of multiple perspectives, 2) respectful dialogue, and 3) responsible action.

The seven weeks international online experience design model is as follows: International online experience Week 1 Introductions - Feb. 6 - 12, 2017. The purpose of international online experience week 1 activity was to help the international online experience US-Mexico students to recognize and appreciate likenesses/similarities and differences in people. To achieve this, the students were distributed in groups of 9 members (from the US and Mexico) to start working on Venn Diagram Get to know Each Other activity. This activity required each team to: 
1) with their international online experience US-Mexico Team members decide on three ways in which they were all alike (writing) those things in the intersecting areas of the diagram),

2) Include an image the represents who you are as a group, and

3) Each international online experience US-Mexico Team members must write in his or her circle three facts that are unique to him or her, as well as an image the represents who you are individually.

4) Finally, as a group develop the group's five golden rules/guidelines for communication within the group and with other international online experience USMexico Teams.

5) Each team was asked to upload its Venn-Diagram in the Venn Diagram Get to know Each Other discussion forum for the rest of the class to review and respond.

International online experience Week 2 - Feb. 13 - 19, 2017 and Week. 3 - Feb. 20 - 26, 2017. The purpose of international online experience week 2 and 3 was to examine demographics trends in the $21^{\text {st }}$ century and focus on Climate Change. These two topics were discussed together due to the link between population growth and climate change. Activities were divided as part 1 due on week 2 , and part 2 due on week 3 .

Week 2 part 1 activity required students to read two articles, one addressing population trends and the other one on climate change, and answer the prompt questions as a group:

1- What are the main points/ideas of the readings?

2- How are both readings related to each other?

3- What are some (minimum two) different US-Mexico perspectives that emerged from your US-Mexico international online experience team discussions of the two global issues?

To answer the questions, US- Mexico international online experience teams were required to meet synchronously (either through skype, adobe connect, or any tool of your choice) to discuss the readings and the possible answers to the questions. The synchronous meeting had a 30 minutes minimum requirement, and should be recorded. The recorded link for the meeting submitted to the professors under week 2 discussion forum together with group's word document answering the questions. 
Week 3 part 2 continued the discussion on population trends and the climate but more specifically to the US and Mexico. Each US- Mexico international online experience team was to:

1. Develop a table highlighting the different US-Mexico perspectives that emerged on the global issues of demographics trends and climate change.

2. Identify one image (picture, photograph, icons, drawing, etc.) that represents/summarize/captures both perspectives for each global issue.

3. Develop a 6 minutes maximum reflective video where they would explain a) why you choose that image and how the image relates to the US and Mexico perspectives, and b) how the image (you may have a different image if your $1^{\text {st }}$ image does not represent your team's interactions) relates to the way the group interact it taking into account the different backgrounds.

4. Upload the US-Mexico international online experience team video under week 3 discussion forum for the professors and classmates to watch and comment on.

International online experience Week 4 - Feb. 27 - March 5, 2017. The purpose of the international online experience week 4 was to discuss the transnational phenomenon of Terrorism. During this week, students worked on:

1. Developing at least three questions based on the readings to foster further understanding/discussions of the readings.

2. One member of the US-Mexico team would post the questions on the discussion board. Each US Mexico team should start a new thread.

3. Each group was asked to post the questions by Thursday so the class and instructors would have until Sunday to respond to at least one question from each US- Mexico team.

International Online Experience Weeks 5 and 6 Final Project. The purpose of week 5 and 6 was for the students to work and present on the final international online experience project based on the international online experience' Student Learning Outcome (SLO): Develop awareness of different perspectives on global issues. The students' awareness in this respect would be reflected in their ability to recognize, discuss, and identify the different US and Mexico perspectives on global issues. The Advisory Role Project consisted on the following: Project Scenario 
Given what you know now and the possible changes in US international policy, You and your US - Mexico team are advisors to a non-profit organization advocating for both nations to work together on a global issue of your choice (ex: human rights, immigration, trade, etc).

\section{Project Task}

Each group was required to develop/create a 6 min max video or PowerPoint with recorded audio. In this task, each group's awareness on different perspectives was to be reflected in their ability to:

1. Identify the historical perspective of the US and Mexico on the global issue.

2. Name and compare the pros and cons of the different perspectives (keeping in mind the US change in Administration).

3. Come up with one recommendation on how both nations can work together on that global issue despite of the different perspectives.

Finally, students were asked to complete a self-reflection self-essay. In this essay, we asked the students to reflect on the questions: 1) What challenges did you encounter while you were working on the final project?, 2) How did you solve them or What steps did you take to solve them?, 3) What was especially satisfying to you about the process or the finished product?, and 4) What did you learn about yourself as you worked on the final project?

\section{Lessons learned}

Implementing international online experience in the classrooms is a transformative experience worth taking. The instructors started the journey with the goal to present to our students a valuable cultural learning experience. From the 7 weeks journey, learning took place at the faculty and students level.

As a faculty, our goal was to design a learning environment where content and cultural awareness would not conflict with each other. Thus, our fall 2016 semester planning led to a very structured international online experience. However, the faculty quickly learned that for all the planning the instructors have done, students experienced some challenges in the following areas:

More time to get to know each other. Based on the students feedback, the one week given to them to get to know each other was not enough. Students in both classrooms, felt rushed to get 
to know each other. Students perceived this activity as the first activity to worked on. In a sense, the students focus on completing the assignment rather than in the interaction itself to get to know each other.

For example, some students stated:

While I was working on activity 1 part 1 , some of the challenges I encountered was effective communication with group and being positive with one another. This challenge occurred when the assignment was close to being due and people were getting anxious to make sure that it was submitted on time. The time difference was where the confusion was coming from.

While working in activity one, a major challenge was to agree on a day and an hour with eight people to do the video conference.

While working on activity 1 part 1 , the real challenge was trying to come together as a team to meet online and discuss. I found that to be a challenge because I was at work, others had to miss class, and time changes interfered. As a team, we were still able to come together and have the meeting. I was able to attend the meeting while working. I was unable to use the video or microphone to speak due to the nature of my job. I was, however, able to hear the discussion and write a comment. I was very satisfied with the finished product because it shows the U.S. and Mexico international online experience team's perspectives about different issues in a concise and easy to understand manner.

Source: the author

Upon reflection from the students' feedback, the instructors decided to include a week before the start of the international online experience, a one-hour adobe connect meeting between both classrooms. The instructors decided to do this to 1) first address both classes at the same time and go over via face-to-face the expectations towards the experience, and 2) to allow the students to start building a sense of learning community. This is meant to bring an added value of networked interactions promoting an initial cultural, linguistic, interpersonal, and motivational development among the students (CANTO; JAUREGI; VAN DEN BERGH, 2013), and their own global competencies.

The instructors also decided to expand the getting to know each other activities from one week to two weeks. During the 1st week, the students, as a class, will work on the getting to know each other through the Social Lounge Discussion Forum. To do this, each student would be asked to post a 10 seconds snapshot addressing: 1) his/her name, 2) country of 
origin, and 3) his/her favorite place on earth (and why?), and asked to review and comment on at least two classmates. During the second week, students would work with their assigned teams on the Getting to Know Each Other Activity Venn Diagram and the group's golden rules of communication.

\section{International Online Learning and Global Learning}

The international online learning activities were designed to foster in students a high level of interaction between both cultures. The variety of activities from discussions forums, videos creation, synchronous and asynchronous meetings required each student to leave their comfort zone and approach the activities with a level of creativity and openness to new perspectives. The activities underlying factor was that students cross-cultural engagement would promote communication with sensitivity to multiple perspectives (OECD, 2016) as well as the dispositions needed to be a global citizen as described by Boix-Mansilla and Jackson (2011).

The final project, the Advisory Role Project, presented to the students the scenario that each group was part of an advocacy, non-profit organization whose task was to present the US and Mexico's perspective on the global issue of their choice, and present a recommendation for both nations to work together. The final project presented to the US and Mexican students a pedagogical task of active engagement to complete, where group participation and communication was a key element of the project delivery. At same level, both instructors expected that communications challenges will emerge given the language difference. Cross-cultural communication was the factor that students talked about on their reflections:

It was challenging to be separated and not know the progress other group members were making

on the project. When we hadn't talked for a few days, it was impossible to know if others were still

working on the project, or if they were focusing on something else. When we were able to get in

touch and communicate our research/voice notes via e-mail, I felt reassured about our progress. 
In the final project there were a couple of difficulties to choose the topic, but we finally decided terrorism and I had to help with the voice notes since my classmates have more difficulties with English language.

We encountered a lot of issues when dealing with our final project. ... We had a huge issue with communicating who was going to turn it in, so that made our submission late.

The biggest challenge I encountered while working on this project was by far communication.

Working with students with very busy schedules in different time zones was quite challenging, but it made the finished product all that much rewarding.

We created a Whatsapp group to communicate and it allowed for everybody to see comments and messages at their own leisure.

Source: the author

As part of the self-assessment, students were asked at the end of the international online experience if the participation in this activity has helped them to re-define their definition of a global citizen, and if they still consider themselves a global citizen. The students' responses articulated that the international online experience had given them a certain understanding of their own global citizenship concept.

Below are some responses from the students' about global citizenship:

For a long time, I thought that a global citizen is a person who can live in different parts of the world, who speaks more than one language and who has friends in various regions of the world. After the international Online Learning experience, I realized that just meeting people and traveling does not make a person global citizen. I learned that a global citizen is an individual who takes the time to learn, respect and have empathy for other cultures. A global citizen is a person who is open to change and has an unbiased perspective on the global problems that our planet carries.

The ... experience allowed me to realize that being a global citizen is much more than knowing and understanding what is going on in the world. Being a global citizen to me now means communicating with others, sharing each other's thoughts and questions, regarding the issues effecting the world. Being able to understand that an issue in one part of the world will eventually effect you in another part of the world. After this international online experience, I consider myself a global citizen because 
\begin{tabular}{l} 
I was able to share my thoughts, thinking, and questions about global issues with \\
individuals from another country. I learned their perspective and they learned my \\
perspective. \\
\hline The ... experience affirmed my definition of a global citizen: an intentional \\
participant in global society who considers factors beyond my immediate \\
environment and experience. The international online experience let me hear \\
firsthand the environment and experiences of others and I still consider myself a \\
global citizen". \\
\hline The ... experience made me realize how difficult it is to communicate with others. \\
It takes plenty of patience to understand other's perspective as well to adapt to how \\
they get things done. I believe this is part of being a global citizen. I believe I have \\
refined my skills in global citizenship, but I still have a long way to go.
\end{tabular} Source: the author

Group work and number of students in the groups. Joining two courses and setting groups was another challenge. In order to promote better interaction among students, the students were placed in groups with members from the US and Mexico. To accommodate all students, the international online learning experience ended up with 5 groups of 9 students in each. The large number of students in the groups did not facilitate the getting together and work as a group. Issues such as time and/or schedule conflicts emerged quickly within the groups.

Capdeferro, Romero \& Margarida (2012) stated in their study on online learners and online collaboration that the reasons leading to online students learning frustrations are: “(a) imbalance in the level of commitment, responsibility, and effort, b) unshared goals and difficulties in organization, c) difficulties in communication/dialogue in terms of frequency, d) imbalance in quality of individual contributions, e) conflict and problems in reaching consensus; f) imbalance between individual expected mark and group mark" (p.32). The instructors recognized that the students experienced some of these frustrations while working on the assignments given the number of students in the groups and the added factor of cultural communication.

The students highlighted a key reflective point to improve the international online experience. By decreasing the number of students in the groups to no more than 6 ( 3 from each side), students will have the opportunity to engage in synchronous "videocommunication that are more static, present visual cues (facial expressions, body language, 
laughter), and play a crucial role in the exchanges intensifying and clarifying meaning and contribute to enhance interpersonal relationships" (CANTO; JAUREGI; VAN DEN BERGH, 2013, p. 86), and decrease the level of frustration online cross-cultural collaboration may bring.

International Online Experience and Overall students reactions. The instructors designed the international online learning experience with the learning objective: "Students will develop awareness of US and Mexico perspectives on global issues". The learning outcome aligns to the three dispositions of developing global competency: 1) recognition of multiple perspectives, 2) respectful dialogue, and 3) responsible action. The overall assessment of the students of the international online learning experience was welcoming and reinforced the course' learning outcomes:

I liked getting to meet new people from a different country. Getting to hear other opinions about America was more eye opening that I already knew it was. Stereotypes, although sometimes done with realizing it are wrong most of the time.

Communication Time difference Experience

Working together with my country's team (we were more united than in past projects)

Hearing the opinion of students from another country --Talking about global issues from more than one perspective

Teamwork work with people from other country practice the English

Teamwork. Cooperation. Hard work.

Source: the author

\section{Conclusion and implications for future practice}

Students in both the US and Mexico engaged in dialogue about global issues and problems and worked together to offer possible solutions. For a period of seven weeks, students engaged in a cross-cultural collaborative learning experiences, a global pedagogy tool, that provided students in both countries a learning environment to explore, compare and contrast global issues perspectives between the US and Mexico. As a result, new insights and deep understanding of cross-cultural perspectives and communication emerged.

The international online learning experience enhanced and reinforced the key dispositions of global competences of understanding multiple perspectives-others' and 
their own, respectful dialogue across cultures, and taking responsible action (BOIXMANZILLA; JACKSON, 2011; BOIX-MANZILLA, 2016). As the students engaged in the international online cross-cultural projects, students from the US and Mexico share a space for dialogue and action. This experience promoted an experimental learning beyond just the prescriptive content knowledge.

For the professors, this experience meant enhancing personal global awareness, perspectives, and engagement; promoting new teaching strategies; integrating teaching with research and service; improvement in online and co-teaching skills; and experiential collaboration. For students, the international online experience offered the opportunity to build diverse personal relationships; offered a motivation to travel and study abroad as the relationships growth even outside the classroom; and most importantly, the development to intercultural awareness, online intercultural communicative competence, digital literacies, and working effectively in virtual teams.

\section{Recommendations}

Based on our observations and students' feedback, we offer the following comments and recommendations. Firstly, the instructors strongly support the inclusion of an international online experience in a course to: (1) internationalize the curriculum, and (2) enhance students' global competencies. This commitment drives the instructors selfassessment and recommendations for the upcoming offering of the second international online experience course:

1- Allow more time to students to get to know each other.

2- Provide to US and Mexico students a brief cultural introduction of each nation.

3- Decrease the number of students per group.

4- Monitor group members' participations.

5- Remaining flexible, though is best recommendation. As the international learning experience starts, the instructors will remain flexible - like in any other learning environment - to unforeseen challenges.

6- Incorporate more Mexican readings.

7- Incorporate Harvard's Project Zero Thinking Routines such as the Claim/Support/Question reasoning routine. 


\section{References}

ABDULLAHI, S. Rethinking global education in the twenty-first century. In: ZAJDA J. (Ed.). Global pedagogies: schooling for the future, p. 23-34. Dordrecht, New York: Springer, 2010.

ALTBACH, P.; KNIGHT, J. The internationalization of higher education: motivations and realities. Journal of Studies in International Education. v.11, n.3-4, p. 290-305. 2007. <http://dx.doi.org/10.1177/1028315307303542>. Accessed Fev16 2018.

BOIX-MANSILLA, V. How to be a GLOBAL THINKER. Educational Leadership, v.74, n.4, p.10-16. 2016.

BOIX-MANSILLA, V.; JACKSON, A. Educating for Global Competence: Preparing Our Youth to Engage the World. Retrieved from: <https://www.asiasociety.org/files/bookglobalcompetence.pdf>. 2011. Accessed Jan08.2018.

CANTO, S.; JAUREGI, K.; VAN DEN BERGH, H. Integrating cross-cultural interaction through video-communication and virtual worlds in foreign language teaching programs: Is there an added value? ReCALL. v.25, n.1, p.105-121. 2013. <http://dx.doi.org/10.1017/S0958344012000274> Accessed Fev17. 2018.

CAPDEFERRO, N.; ROMERO, M. Are online learners frustrated with collaborative learning experiences? The International Review of Research in Open and Distance Learning. v.13, n.2, p.26-44. 2012. Retrieved from <http://www.irrodl.org/index.php/irrodl/article/view/1127>. Accessed Mar12 2018.

CHEN, S.; CAROPRESO, E.; HSU, C.; YANG, J. Cross-cultural collaborative online learning: If you build it, will they come? Global Partners in Education Journal. v.2, n.1, p. 25-4. 2012.

IUSPA, F. Assessing a Historically Hispanic Serving Institution Internationalization Process. Sage Open. v.4, n.3. Jul-Sep 2014. <http://dx.doi.org/10.1177/2158244014552427> Accessed Fev14 2018. 
LANDORF, H.; DOSCHER, S.P. Defining global learning at Florida International University. Diversity \& Democracy. v. 18, n.3, p. 24-25. 2015.

LAW, E.; NGUYEN-NGOC, A. Analysis of cross-cultural online collaborative learning with social software. Interactive Technology and Smart Education. v. 7, n.4, p.247-263. 2010. < http://dx.doi.org/10.1108/17415651011096058>. Accessed Mar21 2018.

OECD. Global Competency for an Inclusive World. Retrieved from: $<$ https://www.oecd.org/education/Global-competency-for-an-inclusiveworld.pdfhttps://www.oecd.org/education/Global-competency-for-an-inclusiveworld.pdf>. 2016. Accessed Mar21 2018.

Partnership for 21st Century Learning. Framework for State Action on Global Education. Retrieved online: <http://www.p21.org/storage/documents/Global_Education/P21_State_Framework_on _Global_Education_New_Logo.pdf>.2014. Accessed Fev06 2018.

PIKE, G.; SELBY, D. Reconnecting: From national to global curriculum. Toronto, Canada: World Wide Fund \& International Institution for Global Education, 1995.

REIMERS, F.; CHOPRA, V.; CHUNG, C.; HIGDON, J.; O'DONNELL, E. Empowering Global Citizens: A World Course. North Charleston; North Carolina: CreateSpace Independent Publishing, 2016.

SUNY, Collaborative Online International Learning. Guide for Collaborative Online International Learning: Course Development. State University of New York: New York, 2017.

YANG, J.; HUIJU, Y.; CEN, S.-J.; HUANG, R. Strategies for Smooth and Effective CrossCultural Online Collaborative Learning. Educational Technology \& Society. v.17, n.3, p. 208-221. 2014.

recebido em 10 julho 2018 / aprovado em 22 outubro 2018

Para referenciar este texto:

IUSPA, F. Infusing an international online learning experience into the curriculum: a United States and Mexico collaboration. Dialogia, São Paulo, n. 30, p. 85-100, set. /dez. 2018. Disponível em: <https://doi.org/10.5585/Dialogia.n30.10774 


\title{
O potencial transformador da arte: um diálogo entre Vigotski e Antonio Candido ${ }^{1}$
}

\author{
The transformational potential of art: a Vigotski and Antonio Candido
}

dialogue

\begin{abstract}
Denise Stefanoni Combinato
Doutora em Saúde Coletiva pela Faculdade de Medicina de Botucatu/Universidade Estadual Paulista. Psicóloga e professora do Departamento de Humanidades do Instituto Tecnológico de Aeronáutica, São José dos Campos, SP - Brasil denisecombinato@hotmail.com
\end{abstract}

"Livros não mudam o mundo, quem muda o mundo são as pessoas.

Os livros só mudam as pessoas."

Mário Quintana

Resumo: Este artigo faz uma reflexão sobre o potencial transformador que a arte, especificamente a literatura e o audiovisual, tem na Educação. Essa reflexão é resultado de um trabalho de pesquisa realizado em uma Escola Estadual de Ensino Médio Integral do Estado de São Paulo, que tem como objetivo investigar se há e quais são os impactos da articulação entre a arte literária e o audiovisual no processo ensino-aprendizagem. Tal reflexão fundamenta-se na Psicologia histórico-cultural e na leitura de duas obras principais: "Psicologia da Arte", de Lev Vigotski (1999) e "O direito à literatura", de Antonio Candido (1988). Entende-se que esse potencial de transformação da arte relaciona-se com o processo de humanização, que envolve a apropriação e a confirmação das características tipicamente humanas.

Palavras-chave: Arte. Literatura. Audiovisual. Educação. Humanização.

Abstract: This article presents a reflection on art's, specifically literature and audiovisuals, transformational potential on Education. This reflection results from a research carried out in a São Paulo State full period high school, aimed to investigate if there are and which are the impacts of literature and audiovisual articulation on the teaching-learning process. Such reflection is grounded on the Socio-historical Psychology and two major books: "Art Psychology" by Lev Vigotski (1999) and "The right to literature" by Antonio Candido (1988). The understanding is that art's transformative potential is related to the humanization process, which involves the appropriation and confirmation of the human typical characteristics.

Keywords: Art. Literature. Audiovisual. Education. Humanization. 


\section{Introdução}

Os livros mudam as pessoas, que mudam o mundo, que muda as pessoas, que mudam...

Por que mudar o mundo e as pessoas? O que mudar no mundo e nas pessoas?

Trataremos aqui de uma única mudança que relaciona mundo e pessoas: a mudança de um ser "candidato à humanidade" (Piéron, s/d, in LEONTIEV, 1978, p.255), regido pelas leis biológicas, para um ser humano regido pelas leis histórico-culturais. Isso significa a mudança de uma condição passiva de adaptação à realidade externa para uma relação ativa e consciente com a realidade, que vise à produção dos meios de sobrevivência.

Essa mudança depende da apropriação daquilo que o gênero humano ${ }^{2}$ já acumulou e produziu historicamente: "para que os indivíduos se insiram na história, humanizando-se, eles precisam de educação, da transmissão da cultura material e simbólica por parte de outros indivíduos" (MARTINS, 2013, p.10). Ou seja, o "mundo", através da educação escolar, precisa disponibilizar essa cultura para que as "pessoas", numa condição ativa, apropriem-se dela e desenvolvam as funções tipicamente humanas.

De acordo com Saviani (1992), "o trabalho educativo é o ato de produzir, direta e intencionalmente, em cada indivíduo singular, a humanidade que é produzida histórica e coletivamente pelo conjunto dos homens" (p. 21). Isso significa que, através do trabalho educativo, o aluno deve apropriar-se dos elementos culturais desenvolvidos ao longo da história para tornar-se humano. A escola é o espaço privilegiado de organização e disseminação desse saber sistematizado, sendo responsável, assim, por disponibilizar essa cultura para formar o ser humano.

Para tanto, não basta assimilar um conhecimento técnico-instrumental; é preciso garantir o acesso aos conhecimentos clássicos, ir além das necessidades básicas de sobrevivência e atingir as necessidades históricas.

A arte é uma dessas necessidades. Candido (1988) defende que não se pode negar aos homens o acesso aos "bens incompressíveis", sob pena de "desorganização pessoal" ou "frustração mutiladora" (p. 174). Segundo o autor, esses bens não são apenas aqueles que asseguram a integridade física como, por exemplo, alimentação, moradia e saúde, mas também aqueles que garantem a integridade espiritual como liberdade, justiça, direito à crença e à opinião, lazer.

Alguns argumentos utilizados por Candido (1988) na defesa de que a arte e a literatura estão nessa categoria (de bens incompressíveis) são: a literatura é uma "manifestação 
universal de todos os homens em todos os tempos" (p.174) e "ninguém é capaz de passar as vinte e quatro horas do dia sem alguns momentos de entrega ao universo fabuloso" (p.174). Ora, se não passamos um dia sequer sem recorrer ao devaneio, então a arte corresponde, de fato, a uma necessidade básica.

Numa perspectiva histórico-cultural, podemos dizer que essas necessidades espirituais estão relacionadas ao processo de humanização, ou seja, ao processo de desenvolvimento do gênero humano, em outras palavras, o desenvolvimento de características tipicamente humanas constituídas ao longo da história da humanidade como, por exemplo, a linguagem, o pensamento e a imaginação, funções tipicamente humanas denominadas de funções psíquicas superiores.

Se a arte é um patrimônio cultural da humanidade e promove o desenvolvimento das funções tipicamente humanas, concordamos com Candido (1988) que elas devem ser entendidas como bens incompressíveis e de acesso a todas as pessoas, sendo a educação escolar responsável pela socialização daquilo que é "clássico", "fundamental", "essencial" (SAVIANI, 1992, p. 21), ou seja, daquilo que "resistiu ao tempo" (p.25), pois "expressa as leis que regem a existência de determinado fenômeno, [...] algo cuja validade é universal" e que "se aplica tanto a fenômenos naturais como sociais" (p.63).

Concluída essa explanação sobre a necessidade de o mundo (com foco aqui na educação escolar) promover o conhecimento às pessoas (inclusive o conhecimento da arte), tendo em vista a transformação das pessoas e do mundo, discutiremos, com base em Vigotski (1999) e Antonio Candido (1988), três características da arte que foram objeto de discussão de um grupo de pesquisadores em uma Escola Estadual de Ensino Médio Integral do Estado de São Paulo: a arte como mediação da cultura; o papel da forma nas obras de arte; e o efeito produzido por elas no sujeito.

\section{Contextualização}

Desde fevereiro de 2017, está sendo desenvolvida uma pesquisa em uma Escola Estadual de Ensino Médio Integral do Estado de São Paulo, com auxílio da Fundação de Amparo à Pesquisa do Estado de São Paulo (FAPESP), cujo objetivo é investigar se há e quais são os impactos da articulação entre a arte literária e o audiovisual no processo ensinoaprendizagem. 
A pesquisa fundamenta-se nos princípios teórico-metodológicos da Psicologia histórico-cultural e o método utilizado é o da pesquisa-ação, caracterizado pela inter-relação entre intervenção (ensino) e produção do conhecimento (pesquisa).

Essa pesquisa envolve duas atividades paralelas e interligadas: 1) a pesquisa-ação com os alunos do Ensino Médio; e 2) o planejamento e a avaliação das atividades de pesquisaação, assim como a formação/capacitação do grupo de pesquisadores constituído por professores e gestores da Educação Básica e pesquisadores externos.

Em relação à pesquisa-ação com os alunos, estão sendo acompanhadas três turmas de alunos que iniciaram o $1^{\circ}$ ano do Ensino Médio em 2017 e encerrarão esse ciclo em 2019. Em cada bimestre, a partir de uma temática previamente estabelecida pelo corpo docente para o semestre ou para o ano, é desenvolvida uma atividade curricular interdisciplinar que articula literatura e audiovisual.

No final de 2017, concluíram o ano letivo nessa escola 356 alunos, sendo 100 alunos concluintes do $1^{\circ}$ ano do Ensino Médio, 137 alunos do $2^{\circ}$ ano e 119 alunos do $3^{\circ}$ ano.

Para a realização do trabalho pedagógico com esses alunos, em 2017 essa escola contava com três membros na equipe gestora (direção e coordenação pedagógica) e 20 professores, sendo uma professora responsável pela Sala de Leitura e três professores acumulando também as coordenações de áreas (Ciências da Natureza e suas Tecnologias; Ciências Humanas e suas Tecnologias; Linguagem, Códigos e suas Tecnologias).

Em relação às atividades de planejamento e avaliação da pesquisa-ação, e formação/capacitação do grupo de pesquisadores, são realizadas discussões teóricometodológicas e vivências sobre a arte, incluindo leitura e discussão de textos e livros teóricotécnicos; leitura e discussão de textos literários; exibição e discussão de curtas e documentários, com objetivo de auxiliar na qualificação da prática profissional dos pesquisadores e subsidiar o desenvolvimento da pesquisa-ação com os alunos.

Em 2017, esse grupo foi composto por professores (seis professoras, sendo três contempladas com bolsa de aprimoramento pedagógico da FAPESP) e gestores (diretora e coordenadora pedagógica) da Escola Estadual, além de três pesquisadoras externas, sendo duas pesquisadoras voluntárias e uma pesquisadora vinculada à Instituição de Ensino Superior, responsável por essa pesquisa.

Foram realizadas, de fevereiro a dezembro de 2017, 25 reuniões com o grupo de pesquisadores, com duração de uma hora e 40 minutos cada.

A reflexão sobre o potencial transformador da arte que esse artigo pretende abordar é fruto principalmente do trabalho desenvolvido com esse grupo de pesquisadores na escola. 


\section{A arte como mediação da cultura}

Vigotski (1999) afirma, em concordância com Guyeau, que a arte é uma "condensação da realidade" (p.315) e Antonio Candido (1988) caracteriza a literatura também como uma "forma de conhecimento" (p.176). Isso não significa que a arte seja uma reprodução da realidade, mas uma criação a partir da realidade. Um exemplo dado por Vigotski (1999) a esse respeito articula vida e arte a um milagre do Evangelho, a transformação da água em vinho: "a arte está para a vida como o vinho para a uva [...] a arte recolhe da vida o seu material mas produz acima desse material algo que ainda não está nas propriedades desse material” (p.307-308).

Em uma das reuniões do grupo de pesquisadores, assistimos a alguns trechos do documentário “O povo brasileiro", de Isa Grinspum Ferraz (2000), realizado a partir da obra de Darcy Ribeiro, "O povo brasileiro: a formação e o sentido do Brasil”" (1995). O documentário discute a formação do povo brasileiro, com destaque para as matrizes indígena, luso e africana. São apresentados aspectos de cada cultura que resultaram na miscigenação do povo brasileiro. O documentário contou com a participação, dentre outros, de Darcy Ribeiro, Chico Buarque, Gilberto Gil, Tom Zé e Antonio Candido.

Algumas manifestações das professoras, após a exibição do documentário, foram: "Você se vê ali [...] isso sou eu"; "Leva a gente para uma realidade de forma poética"; "Redescobrir-me como brasileira não tem preço!”.

A arte possibilita, além do conhecimento da realidade, um "redescobrir-se", uma vez que mobiliza "a subjetividade para muito além da cotidianidade, num movimento em direção tanto ao núcleo da própria personalidade como da realidade social” (DUARTE et al., 2012, p. 36).

Daí a importância de promover o acesso às obras literárias e audiovisuais aos professores em espaços de formação docente. O primeiro obstáculo para acessar os níveis eruditos, de acordo com Candido (1988), não é a incapacidade, mas a oportunidade. Exceto a professora de História, que foi quem indicou o documentário, as outras não demonstraram conhecê-lo. A exibição e a discussão mobilizaram o grupo para o conhecimento do documentário na íntegra e para a exibição aos alunos.

Vigotski (1999) também afirma que "a arte é o social em nós" (p. 315), o que significa que tanto a apropriação da arte como a objetivação de emoções e sentimentos em um objeto artístico envolvem uma apropriação social, uma mediação cultural. Podemos dizer que a arte caracteriza-se por uma "unidade dialética entre a singularidade e a universalidade, entre a 
objetividade e a subjetividade" (DUARTE, 2009, p.469), em um movimento de humanização. Assumpção e Duarte (2015) explicam que "a arte - seja na recepção ou na criação - possibilita aos indivíduos entrarem em contato com sentimentos que ultrapassam as experiências pessoais e se aproxima do gênero humano" (p.240).

\section{O papel da forma nas obras de arte}

De acordo com Candido (1988), "o conteúdo só atua por causa da forma”, ou seja, "a mensagem é inseparável do código, mas o código é a condição que assegura o seu efeito" (p.178).

Vigotski (1999) também defende a importância da forma na constituição da obra. Para o autor, é a contradição entre o conteúdo e a forma que produz a reação estética:

[...] durante séculos os especialistas em estética vêm afirmando a harmonia da forma e do conteúdo, dizendo que a forma ilustra, completa, acompanha o conteúdo, e de repente descobrimos que isto é o maior dos equívocos, que a forma combate o conteúdo, luta com ele, supera-o, e que nessa contradição dialética entre conteúdo e forma parece resumir-se o verdadeiro sentido psicológico da nossa reação estética (p. 199).

Após a leitura do texto "O direito à literatura", de Antonio Candido (1988) com o grupo de pesquisadores, e a discussão de que a literatura "humaniza em sentido profundo porque faz viver" (p. 176), uma professora relatou que sentia sede quando lera o livro "Vidas Secas", de Graciliano Ramos.

Qual o motivo de a professora ter sentido sede ao ler "Vidas Secas"? Será o conteúdo da obra? Será que um texto jornalístico que trate da seca no nordeste produziria o mesmo efeito?

De acordo com esses autores, não é o conteúdo ou puramente o conteúdo ou o conteúdo dissociado da forma que produz esse efeito; é a forma, a maneira como a obra de arte é elaborada e articulada ao conteúdo, que tem um papel fundamental.

\section{$O$ efeito da arte}

Partindo da realidade, mas não nos restringindo a ela; e com uma construção estética elaborada entre forma e conteúdo; a obra de arte, numa analogia à transformação da água em vinho, também provoca a transformação do ser humano como nos indica Vigotski (1999): 
[...] a verdadeira natureza da arte sempre implica algo que transforma, que supera o sentimento comum, e aquele mesmo medo, aquela mesma dor, aquela mesma inquietação, quando suscitadas pela arte, implicam o algo a mais acima daquilo que nelas está contido (p.307).

Essa transformação das emoções provocada pela arte é a catarse. Para o autor,

[...] toda obra de arte [...] encerra forçosamente uma contradição emocional, suscita séries de sentimentos opostos entre si e provoca seu curto-circuito e destruição. A isto podemos chamar o verdadeiro efeito da obra de arte, e com isto nos aproximamos em cheio do conceito de catarse (VIGOTSKI, 1999, p.269).

Consonante a essa visão, Candido (1988) afirma que a palavra organizada promove a organização dos sentimentos e pensamentos:

[...] o caráter de coisa organizada da obra literária torna-se um fator que nos deixa mais capazes de ordenar a nossa própria mente e sentimentos; e, em consequência, mais capazes de organizar a visão que temos do mundo (p. 177).

Apresentamos na sessão anterior o relato de uma professora que sentia sede ao ler "Vidas Secas". Outra professora, que afirmava que antes de participar do grupo de pesquisadores entendia a literatura como algo "separado da vida [...] e da relação com a sociedade", leu "Vidas Secas" após presenciar o relato da colega.

Essa professora afirmou que teve uma boa formação acadêmica, em um modelo tradicional, mas não teve uma formação estética e expressiva ao longo dos seus estudos. Por isso, frequentemente, valorizava o espaço de formação desse grupo, seja como subsídio necessário para a condução da pesquisa-ação, seja como aperfeiçoamento profissional e pessoal.

Em outro momento, essa professora, que afirmou ter descoberto a literatura no grupo de pesquisadores, relatou que leu um trecho de "Vidas Secas" aos seus alunos "para que eles pudessem sentir [...] sem estar no local", como uma forma de mobilizar o interesse deles pela literatura e o conhecimento da cultura pela literatura. Ela contou aos alunos sobre sua experiência com o livro. Disse que antes da leitura de "Vidas Secas", "sabia, mas não sentia", ou seja, ela sabia da condição da seca no nordeste brasileiro, em função da formação acadêmica, mas sentiu essa condição com a obra literária. Vários alunos manifestaram interesse e leram essa obra. 


\section{Considerações finais}

Buscamos abordar neste artigo o potencial de transformação da arte a partir da discussão trazida principalmente por dois autores, Vigotski e Antonio Candido, articulando essa discussão ao trabalho de pesquisa em desenvolvimento em uma Escola Pública de Ensino Médio Integral, com foco no trabalho realizado com o grupo de pesquisadores.

Os principais aspectos abordados pelo artigo foram: a arte como mediação da cultura, ou seja, a arte como forma de apropriação da realidade e de conhecimento; a composição da arte, integrando conteúdo e forma, com destaque para a interferência da forma no conteúdo para a produção da obra de arte; e, por fim, o efeito que a arte provoca no ser humano, em função da elaboração psíquica exigida a partir da contradição emocional desencadeada pela vivência da obra.

Entende-se que o potencial de transformação da arte relaciona-se com o processo de humanização na medida em que proporciona o acesso à produção historicamente acumulada e o desenvolvimento de funções psíquicas superiores ou a confirmação de traços essenciais ao ser humano como:

[...] o exercício da reflexão, a aquisição do saber, a boa disposição para com o próximo, o afinamento das emoções, a capacidade de penetrar nos problemas da vida, o senso da beleza, a percepção da complexidade do mundo e dos seres, o cultivo do humor (CANDIDO, 1988, p.180).

A leitura da obra "Vidas Secas", por exemplo, como consequência da participação em um grupo de pesquisadores que integra professores e gestores da Educação Básica com pesquisadores externos, parece ter provocado uma transformação em uma professora e, possivelmente, nos alunos com os quais trabalhou. Saber sem sentir é diferente de sentir mesmo distante de tempo e espaço. O acesso a essa obra parece ter transformado a sua relação com esse conhecimento, talvez ampliando sua compreensão da realidade, de si e do outro,

Os livros mudam as pessoas, que mudam o mundo, que muda as pessoas, que mudam...

\section{Notas explicativas}

1. Apoio: Fundação de Amparo à Pesquisa do Estado de São Paulo (FAPESP), processo no 2014/50841-4.

2. Gênero humano diz respeito ao processo de apropriação / objetivação das características humanas criadas socialmente ao longo da história. Nas palavras de Saviani (1992), refere-se à “formação da humanidade em cada indivíduo singular" (p.30). 


\section{Referências}

ASSUMPÇÃO, M. C.; DUARTE, N. A arte e o ensino de literatura na educação escolar.

Contexto, n.27, p.238-258, 2015. Disponível em: http://www.periodicos.ufes.br/contexto/article/view/10422/7354 Acesso em: 30 jan 2018.

CANDIDO, A. O direito à literatura. In: Vários escritos. 3. ed. São Paulo: Duas cidades, 1988. p. 169-191.

DUARTE, N. Arte e educação contra o fetichismo generalizado na sociabilidade contemporânea. Perspectiva, v.27, n.2, p.461-479, 2009. Disponível em: https://periodicos.ufsc.br/index.php/perspectiva/article/download/2175.../15289 Acesso em: 31 jan 2018.

DUARTE, N. et al. O ensino da recepção estético-literária e a formação humana. Eccos Rev. Cient., n.28, p.31-48, 2012. Disponível em: <http://www.redalyc.org/pdf/715/71523339003.pdf>. Acesso em: 31 jan. 2018.

LEONTIEV, A. O desenvolvimento do psiquismo. Tradução de M. D. Duarte. Lisboa: Livros Horizonte, 1978.

MARTINS, L. M. O desenvolvimento do psiquismo e a educação escolar: contribuições à luz da psicologia histórico-cultural e da pedagogia histórico-crítica. Campinas/SP: Autores Associados, 2013.

O POVO brasileiro. Direção de Isa Grinspum Ferraz. São Paulo: Fundação Darcy Ribeiro, TV Cultura e GNT, 2000. 2 DVD (280 min).

SAVIANI, D. Pedagogia histórico-crítica: primeiras aproximações. 3. ed. São Paulo: Cortez; Autores Associados, 1992.

VIGOTSKI, L. S. Psicologia da arte. Tradução de P. Bezerra. São Paulo: Martins Fontes. 1999. 
recebido em 02 fev. 2018 / aprovado em 01 out. 2018

Para referenciar este texto:

COMBINATO, D. S. O potencial transformador da arte: um diálogo entre Vigotski e Antonio Candido. Dialogia, São Paulo, n. 30, p. 101-110, set. /dez. 2018. Disponível em: $<$ https://doi.org/10.5585/Dialogia.n30.8328 


\title{
Escola e interculturalidade: elementos para pensar a diversidade no currículo
}

\author{
School and interculturality: Elements to think diversity in the curriculum
}

\author{
Luciana Pacheco Marques \\ Doutora em Educação pela Universidade Estadual de Campinas. \\ Professora Titular da Faculdade de Educação e do Programa de Pós-Graduação em \\ Educação da Universidade Federal de Juiz de Fora. Juiz de Fora - MG - Brasil \\ luciana.marques65@gmail.com \\ Gabriela Silveira Meireles \\ Doutora em Educação pela Universidade Federal de Minas Gerais. \\ Professora Adjunta da Faculdade Ubaense Ozanam Coelho, \\ dos Cursos de Pedagogia e de Psicologia. Ubá - MG - Brasil \\ gabrielasilveirameireles@gmail.com
}

\begin{abstract}
Resumo: O objetivo é pensar que a interculturalidade, enquanto mecanismo entre diferentes culturas, tornou-se uma perspectiva de se pensar a educação na sua globalidade. A perspectiva da interculturalidade contraria o discurso etnocêntrico, evidenciando as contradições nas práticas curriculares explícitas e implícitas, operando uma "rachadura" no sistema escolar e educacional, levando os/as profissionais que nele estão envolvidos/as a uma reflexão que propõe à necessidade de mudança e de desconstrução. Cabe-nos reconhecer que a complexidade dos enunciados denuncia a necessidade do enfrentamento das relações dominantes de poder na escola, visando torná-la um lugar de encontro, de aproximação e de articulação das diferenças, a partir da incorporação das relações interculturais e da promoção do diálogo entre os padrões culturais existentes e suas múltiplas significações. Torna-se um desafio à construção de uma nova relação com o currículo entendido como processo de construção social.
\end{abstract}

Palavras-chave: Escola. Currículo. Diferenças. Interculturalidade.

Abstract: The goal is to think that interculturality, as a mechanism between different cultures, has become a perspective of thinking about education as a whole. The intercultural perspective contradicts the ethnocentric discourse, evidencing the contradictions in explicit and implicit curricular practices, operating a "crack" in the school and educational system, leading the professionals who are involved in it to a reflection that proposes the need for change and deconstruction. We must acknowledge that the complexity of the statements denounces the need to confront the dominant power relations in school, aiming to make it a place for meeting, approaching and articulating differences, starting with the incorporation of intercultural relations and the promotion of dialogue between existing cultural standards and their multiple meanings. It becomes a challenge to build a new relationship with the curriculum understood as a process of social construction.

Keywords: School. Curriculum. Differences. Interculturality.

A lógica de mercado, entendida como uma nova ditadura de organização social, tem promovido o alargamento da exclusão de povos dos continentes, geralmente aqueles que pouco dominam os códigos da modernidade e, portanto, estão à margem da competitividade e do poder de consumo. Essas minorias têm, por sua vez, incitado o processo de 
“hibridização cultural” (GARCIA; CANCLINI apud CANDAU, 2000, p. 48) e começam a formar linhas de resistência e reação a esse sistema excludente.

A interculturalidade enquanto mecanismo de diálogo entre as diferentes culturas, tornou-se uma perspectiva de se pensar a educação. No entanto, seu nascimento se deu para o controle dos conflitos causados pela exclusão, devendo já superar esse motivo inicial. E como diz Candau (2000, p. 51): "Hoje urge ampliar este enfoque e considerar a educação intercultural como um princípio orientador, teórica e praticamente, dos sistemas educacionais na sua globalidade".

Nos Estados Unidos, movimentos de minorias étnico-culturais, principalmente de negros, impulsionou a necessidade de que novas comunidades, não hegemônicas, fossem ouvidas. Já no caso europeu, o movimento migratório e a inserção de estrangeiros nas escolas públicas europeias, configura-se na América Latina a preocupação com as populações indígenas. A autora ressalta o pioneirismo dos países latinos, em especial o Peru, que na década de 50, havia estabelecido a educação popular.

Apesar da defesa da perspectiva intercultural, o que ainda se percebe nas escolas é uma cultura hegemônica, de caráter uno, avesso ao diverso e às manifestações dessa diversidade. Há uma “desconexão entre a cultura escolar e a cultura social” (CANDAU, 2000, p. 52). Muito do que se ensina nas escolas não é o que se aprende na vida ou o que é exigido dos/as alunos/as em suas tarefas diárias e cotidianas.

Em suas origens a escola atendeu aos apelos da modernidade e a propagação da legitimidade da ciência clássica, e sob os ideais de igualdade, e universalidade, impermeabilizou-se aos contextos de sua clientela. Além desse primeiro equívoco, a escola insiste em historicizá-lo: mantém a cultura padronizada, ritualística, formal, dispensando a inserção dos avanços científico-tecnológicos e resiste a valorizar as diversas linguagens e expressões sempre presentes no meio social.

A superação da multiculturalidade pressupõe tentativas de inclusões efetivas dos grupos marginalizados, de forma permanente e com incansável objetivo de estabelecer relações dialógicas e democráticas entre todos os universos culturais. A aplicação desses conceitos demanda a superação dos artificialismos nos ambientes escolares de reservarem alguns momentos para o trabalho multicultural, a restrição do tema a algumas áreas curriculares ou a alguns grupos. A proposta deve ser a de se "partir da diferença", ou seja, da certeza da diversidade, conforme defendido no documento escrito num debate na Bolívia em 1996 sobre o tema “Educação Popular e Pedagogia da Diversidade". É preciso se decidir por um projeto educativo global e não universal, igualitário e não igual em suas ofertas. 
A perspectiva da interculturalidade contraria o discurso etnocêntrico, evidenciando as contradições nas práticas curriculares explícitas e implícitas. Enfim, insinua questões radicais à escola de hoje a todo o tempo, advertindo-a de sua ação desconexa e função instável. Ao fazer isso, a proposta intercultural de trabalho opera uma "rachadura" no sistema escolar e educacional, levando os profissionais que nele estão envolvidos a uma reflexão que propõe a necessidade de mudança e de desconstrução.

Pensando nessa necessidade da desconstrução de modelos unívocos de educação, bem como da revisão de posturas e experiências didático-pedagógicas homogeneizantes e binárias, Fleuri e Souza (2003) apontam para a existência de um entrelugar, que caracterizaria uma fronteira entre culturas diferentes que, a partir de suas complexas e diferentes experiências de aprendizagem, pudessem buscar a construção de novas perspectivas educacionais, através de relações interculturais.

Diante da complexidade social explicitada pela diversidade de culturas e identidades produzidas, seus deslocamentos e descontinuidades, torna-se relevante perceber que cada sujeito possui várias identidades e que "cada uma dessas identidades assume significados específicos conforme os sujeitos, as relações sociais e os contextos históricos em que se colocam" (FLEURI; SOUZA, 2003, p. 55). Essa visão remete à ideia de hibridização, que segundo Moreira (2001, p. 77), consiste em

\begin{abstract}
um modo de produção cultural, um processo em que distintos discursos são mobilizados, selecionados, incorporados, misturados e traduzidos para um dado ambiente. Nesse movimento, os marcadores originais dos discursos tendem a ser esquecidos, abandonados. As características do contexto de origem deixam de ser reconhecidas. Na nova montagem de conceitos e figuras, nas novas séries e equivalências discursivas, novos sentidos são criados.
\end{abstract}

No campo do currículo, este processo torna-se essencial no sentido de permitir a desconstrução, a crítica e a reformulação dos conteúdos tradicionais em confronto com os novos olhares produzidos. De acordo com Garcia e Moreira (2003, p. 9), esta lógica criaria a possibilidade de ver a "sala de aula como um espaço de ressignificação de conhecimentos, de produção de novos conhecimentos, de problematização dos diferentes conhecimentos, tal como eles estão postos na sociedade".

Com o entendimento de que não é possível a construção de uma identidade única capaz de englobar as diferentes identidades dos sujeitos, Fleuri e Souza (2003, p. 57) propõem o deslocamento de uma política da identidade para uma política da diferença, com o objetivo de "compreender a densidade, a dinamicidade e a complexidade dos significados que eles 
tecem". Na tentativa de fugir da lógica binária nas relações interculturais, faz-se necessária a superação da concepção de dominação cultural para que seja possível a valorização do hibridismo das identidades e do diálogo possível entre os diferentes sujeitos históricos e culturais envolvidos numa relação que visa ao deslocamento de sentidos hegemônicos para o reconhecimento dos vários sentidos possíveis.

Ao prever uma possível articulação entre os elementos antagônicos ou contraditórios numa relação intercultural, Fleuri e Souza (2003) mostram que, nesse espaço de hibridismo, não se trata de uma coisa (dominantes) nem de outra (dominados), nem mesmo da superposição de ambas as categorias (dominantes e dominados), mas de

um entrelugar que contestaria os termos e o território de ambas as categorias. Isso possibilita ir além e despertar o desejo de outro lugar e de outra coisa que, nesse caso, poderia ser identificado como novas possibilidades de relações pessoais e sociais entre sujeitos marcados por uma política de diferenças (FLEURI; SOUZA, 2003, p. 62).

De acordo com Bhabha apud Fleuri e Souza (2003, p. 63), essa complexidade da relação entre culturas nos incita a pensar na existência de uma "fronteira cultural" como espaço intervalar que se configura como "espaço de intervenção (tensão-negociaçãotradução) que introduz a 'reinvenção criativa da existência”'. É importante destacar, porém, que nos diferimos culturalmente não apenas dos povos distantes, mas também daqueles com que convivemos nos espaços cotidianos, entre eles a escola. Daí a importância de fazermos da escola um espaço em que possam ser construídas outras formas de relação que não a visão hierarquizada e purificada das culturas, que evidencia uma lógica homogeneizante do conhecimento, onde se exerce o poder hegemônico de educadores e educadoras sobre os alunos e alunas.

A ideia de bibridismo, que pressupõe a interação entre diferentes culturas onde se produzem novos valores numa fronteira que permite o diálogo, um "entrelugar, em que preconceitos e estereótipos podem ser desfeitos ou ressignificados" (AZIBEIRO, 2003, p. 93). Neste espaço de possibilidades, a educação se impõe como elemento articulador de encontros e confrontos entre diferentes culturas que, por meio dos significados produzidos, promove a interação entre as diversas maneiras de entender a realidade e produzir subjetividades a partir desta inter-relação. Para Bhabha apud Azibeiro (2003, p. 95),

o contexto cultural híbrido não é o espaço da síntese, mas da ambivalência. Ou seja, quando pessoas ou grupos de diferentes culturas se relacionam, o que acontece de mais importante não é a simples mistura, mas sobretudo 
a pluralidade dos significados, que possibilita a emergência de uma multiplicidade de sentidos em interação.

Da mesma forma, Bakhtin apud Azibeiro (2003, p. 96) descreve o sentido polifônico destas múltiplas vozes em interação, analisando "a linguagem como realidade viva e histórica", onde os vários sentidos encontram lugar para se expressar e se influenciar mutuamente. A escola é justamente esse lugar em que as várias "vozes" e os vários "sentidos" se encontram para dar lugar à multiplicidade. Ela é o lugar vivo de interação entre as diferentes culturas. Ela é o berço das misturas de todos os matizes!

Com isso, Azibeiro (2003, p. 97) nos alerta sobre a importância da ruptura com modelos rígidos e prontos e assume as várias possibilidades de atuação, de maneira que "a diversidade e complexidade do que chamamos popular desafia permanentemente qualquer enquadramento que se pretende único, mais correto ou mais verdadeiro". Percebemos, então, que a proposta de educação intercultural implica em uma mudança paradigmática que envolva a revisão de nossas concepções de mundo, no sentido de incorporar e articular diferentes maneiras de pensar, sentir e agir como parte integrante de contextos complexos que produzem significados múltiplos e próprios, que nos obrigam a reconhecer outras possibilidades de leitura da realidade.

Por aqui passa o questionamento sobre as práticas escolares desenvolvidas, as quais na maioria das vezes apenas reforçam a estrutura disciplinar a partir de concepções estereotipadas, sem uma reflexão crítica acerca do papel da escola enquanto um espaço de encontro entre diferentes culturas e identidades plurais. Como expõem Fleuri e Souza (2003, p. 65), "as relações entre os diferentes sujeitos, que agenciam relações entre suas perspectivas ópticas e éticas, constituem-se como o próprio lugar do aprender (e requerem o desenvolvimento de uma pedagogia do acolher e do escutar o outro)".

Trata-se da construção de um novo olhar sobre o outro, que nos convida ao deslocamento do conhecido para o desconhecido enquanto possibilidade de uma interrelação que busque "compreender os sentidos que suas ações assumem no contexto de seus respectivos padrões culturais" (FLEURI; SOUZA, 2003, p. 69). Desse modo, percebemos que as relações interculturais podem ser essenciais na ruptura com os processos de exclusão, no sentido de promover a convivência entre diferentes grupos que se identificam por determinada característica comum em um dado momento e permitir a construção de novas aprendizagens numa teia complexa de significações diversas. Nesse sentido, Fleuri e Souza (2003, p. 73) afirmam que: 
a educação intercultural ultrapassa a perspectiva multicultural, à medida que não só reconhece o valor intrínseco de cada cultura e defende o respeito recíproco entre diferentes grupos identitários, mas também propõe a construção de relações recíprocas entre esses grupos.

Um desafio se impõe, então, à formação de educadores/as: o questionamento de práticas monoculturais e etnocêntricas, de modo a construir outras formas de pensar o processo de aprendizagem, a partir do desafio da complexidade envolvida nas relações cotidianas da escola. Para Morin apud Fleuri e Souza (2003, p. 75), "a complexidade implica perceber os diferentes sujeitos e orientar suas relações e interações segundo uma lógica (ou paradigma epistemológico) capaz de compreender a relação da unidade do conjunto com a diversidade de elementos que o constituem".

Assim, cabe-nos reconhecer que a complexidade dos enunciados denuncia a necessidade do enfrentamento das relações dominantes de poder na escola, visando torná-la um lugar de encontro, de aproximação e de articulação das diferenças, a partir da incorporação das relações interculturais e da promoção do diálogo entre os padrões culturais existentes e suas múltiplas significações.

Garcia e Moreira (2003, p. 13) defendem, pois, que "a sala de aula deveria ser um riquíssimo espaço de diferentes saberes que se cruzam, entrecruzam, entram em conflito, produzindo novas possibilidades de compreensão do mundo e aumentando a compreensão que cada um pode ter de si mesmo".

Para que isto ocorra, precisamos buscar romper com a visão de escola que apenas reproduz uma dada cultura e formas de organização hegemônicas e refletir sobre a complexidade das relações estabelecidas neste espaço, para que se permita a afirmação das diferentes subjetividades e, ao mesmo tempo, a construção de relações interculturais democráticas entre a própria cultura escolar e o espaço cultural da comunidade, bem como das produções de significados trazidas pelos alunos em convívio nessa comunidade.

Ainda prevalece no imaginário dos(as) educadores(as) a noção de carência cultural das classes populares, descrita por Azibeiro (2003, p. 86) como a ideia de que "a cultura (ou falta de cultura) das pessoas de classes populares é que determina a incapacidade de permanência de seus filhos na escola”. Na verdade, esta concepção somente vem demonstrar que a escola se pauta por valores universais de uma cultura hegemônica, que acaba por se colocar como superior às outras manifestações culturais e culmina com a negação das diferenças. 
Existe, porém, uma outra forma de lidar com a diversidade cultural que se define pela assunção da diferença cultural, que "não apenas admite a existência de diferentes culturas, mas busca entender a singularidade e a originalidade de linguagens, valores, símbolos e estilos diferentes de comportamento que são tecidos pelas pessoas em seu contexto histórico e social peculiar" (AZIBEIRO, 2003, p. 87). Nessa perspectiva, a escola passa a assumir a construção de seus processos educativos com base nas relações interculturais, onde a interação e o diálogo produzam novos significados sobre os diferentes contextos culturais.

Ao compreendermos que a diversidade se faz presente inclusive dentro de uma dada cultura, conforme a singularidade de seus integrantes, torna-se indispensável a construção de relações interculturais na educação. A partir do conceito de diferença cultural, Bhabha apud Azibeiro (2003, p. 93), destaca que as diferenças culturais não podem ser entendidas como

dados ou evidências, que se manifestam naturalmente como antagonismos, mas como construções histórico-culturais, que decorrem de relações de poder, nas quais os diferentes grupos sociais, particularmente os subalternos, podem redescobrir e reconstruir o valor positivo de suas culturas e experiências específicas - ressignificando-as.

No sentido de buscar a ruptura com a estrutura disciplinar da escola que veicula somente uma forma de conhecimento cientificamente produzido e a introdução de novas articulações entre as diversas dimensões dos fenômenos a serem estudados, Morin apud Azibeiro (2003, p. 101-2-3) expõe três metáforas que nos permitem compreender a complexidade das relações reais:

a hologramática é definida a partir da noção de holograma [...] o todo só
existe a partir das e nas conexões entre as partes. E é também nessa
interação que cada uma das partes continuamente se reconstitui e recria
seus sentidos e seus contextos [...]. Já a organização recursiva e retroativa
é o entendimento de que os efeitos e produtos são necessários à própria
causação de um fenômeno e à sua própria produção, ou seja, o efeito
retroage sobre o fenômeno que o causou, modificando-o. Cada pessoa é,
ao mesmo tempo, causa e efeito de suas relações sociais, das interações
que estabelece [...]. A dialógica, já mencionada anteriormente, refere-se à
compreensão de que não é possível entender a realidade a partir de uma
única verdade [...] O mundo pode ser reconhecido a partir de diferentes
lógicas, constituídas a partir das várias perspectivas que estão em
confronto ou interação.

Sendo assim, pensar a partir do paradigma da complexidade pressupõe a eliminação de padrões rígidos e lineares de explicação da realidade, como também a consideração das 
interconexões produzidas especificamente no espaço intercultural de relações a partir dos diferentes contextos, lógicas explicativas e interpretações e significados possíveis. Azibeiro (2003, p. 104) acrescenta que o pensamento complexo a ser refeito continuamente e que consiste em "um pensamento que pratica o abraço e se prolonga na ética da solidariedade. Solidariedade que não se afirma em discursos ou palavras de ordem, mas é construída no dia a dia, nas ações e situações concretas em que nos encontramos".

A partir desta concepção de mundo aberta a todas as possibilidades, passamos a rever o processo educativo e a olhar o aluno através de suas potencialidades, refletindo sobre as possibilidades de lhe oferecermos relações produtivas de aprendizagem na interação com a diversidade. Pensando mais especificamente no cotidiano da sala de aula, torna-se um desafio à construção de uma nova relação com o currículo entendido como processo de construção social, através da interação entre o local e o global, o individual e o coletivo, na perspectiva do reconhecimento do caráter plural da educação escolar que deve promover a articulação entre as diferenças que favoreçam o exercício de uma cidadania também plural em consonância com a realidade pertencente ao cotidiano escolar.

\section{Referências}

AZIBEIRO, Nadir Esperança. Educação intercultural e complexidade: desafios emergentes a partir das relações em comunidades populares. In: FLEURI, Reinaldo Matias (Org.). Educação intercultural: mediações necessárias. Rio de Janeiro: DP\&A, 2003.

CANDAU, Vera Maria (Org.). Reinventar a escola. 3. ed. Petrópolis: Editora Vozes, 2000.

FLEURI, Reinaldo Matias; SOUZA, Maria Izabel Porto de. Entre limites e limiares de culturas: educação na perspectiva intercultural. In: FLEURI, Reinaldo Matias (Org.). Educação intercultural: mediações necessárias. Rio de Janeiro: DP\&A, 2003.

GARCIA, Regina Leite; MOREIRA, Antônio Flávio. Começando uma conversa sobre currículo. In: - (Org.). Currículo na contemporaneidade: incertezas e desafios. São Paulo: Cortez, 2003. 
MOREIRA, Antônio Flávio. A recente produção científica sobre currículo e multiculturalismo no Brasil (1995-2000): avanços, desafios e tensões. Revista Brasileira de Educação. 24a Reunião Anual da ANPED. Caxambu, MG, 2001.

recebido em 10 jun. 2018 / aprovado em 01 out. 2018

Para referenciar este texto:

MARQUES, L. P.; MEIRELES, G. S. Escola e interculturalidade: elementos para pensar a diversidade no currículo. Dialogia, São Paulo, n. 30, p. 111-119, set./dez. 2018. Disponível em: <https://doi.org/10.5585/Dialogia.n30.8783> 


\title{
Vamos brincar na terra? uma experiência de
} valorização e resgate da cultura infantil com moradores da comunidade de Arraiol na

\author{
Amazônia Amapaense
}

Are we going to play on Earth? an experience of valuing and rescuing

children's culture with residents of the community of the Amapaense Amazon

Priscilla Pantoja do Nascimento Brandão Mestranda em Educação na Universidade Federal do Amapá. Macapá - AP - Brasil prilpe@outlook.com

Ângela do Céu Ubaiara Brito Doutora em Educação pela Universidade de São Paulo. Professora da Universidade do Estado do Amapá. Macapá - AP - Brasil angela.brito@ueap.edu.br

Resumo: O trabalho discute o brincar ribeirinho da comunidade de Arraiol - Arquipélago do Bailique-AP. Investiga-se como o brincar contribui para a constituição da cultura infantil desta comunidade? Objetivou-se analisar o brincar, os brinquedos e brincadeiras para compreender como essas práticas sociais influenciam na constituição da cultura infantil do contexto investigado. O estudo utiliza como fundamentação, autores como Dewey (1976), na compreensão de que a criança vive a experiência como processo de aprendizagem, em Brougère (2012) que analisa o brincar como fenômeno cultural em uma perspectiva sociológica. Outro eixo de análise sustenta-se no diálogo acerca da interpretação das culturas em Geertz (1989), dentre outros. A metodologia fundamentouse no paradigma qualitativo, no uso da História Oral. Os resultados parciais demonstram que o brincar da terra é presente na comunidade. Mas, que é necessário um enfoque maior nos estudos envolvendo a temática, já que as produções ainda são escassas, principalmente na Amazônia Amapaense.

Palavras-chave: Brincar. Culturas infantis. Comunidades Ribeirinhas. Multiculturalismo. História Oral.

\begin{abstract}
The work discusses the play Riverside of the community of Bailique-AP archipelago. Do you investigate how play contributes to the creation of children's culture in this community? It was aimed to analyze the play, the toys and games to understand how these social practices influence the Constitution of the child culture of the context investigated. The study uses as grounds, authors such as Dewey (1976), in the understanding that the child experiences the experience as a learning process, in Brougère (2012) that analyzes the play as cultural phenomenon in a sociological perspective. Another axis of analysis is maintained in the about dialogue of the interpretation of Cultures in Geertz (1989), among others. The methodology was based on the qualitative paradigm, in the use of Oral History. The partial results show that the play of the Earth is present in the community. But that a greater focus is needed in the studies involving the thematic, since the productions are still scarce, especially in the Amapaense Amazon.
\end{abstract}

Key words: Play. Children's cultures. Riverside communities. Multiculturalism. Oral history. 



\section{Introdução}

O trabalho aborda a investigação do brincar e a cultura infantil, que se fundamenta na história oral, peculiar de vivencias na comunidade ribeirinha, realizada na comunidade de Arraiol, no Arquipélago do Bailique- AP, na Amazônia Amapaense. Propõe estudar os saberes culturais do brincar dos moradores para entender como a criança constrói seu próprio conhecimento social e cultural, assim investiga o brincar como um elemento mediador para a compreensão da contribuição dos jogos, brinquedos, brincadeiras na constituição das culturas infantis.

Os diálogos envolvendo a cultura, e as culturas infantis mais especificamente, aproximam-se da temática multicultural, quando se referem a forma como se enxerga a criança e do espaço que ela ocupa atualmente na sociedade, pois a conjuntura atual costuma naturalizar a estrutura social desigual e adultocêntrica existente, que não leva em consideração as vozes, saberes e potencialidades da criança, dando a entender que são seres ignorantes, com saberes superficiais e que por isso não tem algo importante a expressar. Ainda nos dias de hoje, a criança é constantemente estigmatizada, vista de forma estereotipada, como ingênua e facilmente manipulável.

Por conta dessa invisibilidade que a ela tem sido atribuída, o referido estudo reflete a importância que a criança e sua cultura têm na sociedade, trazendo o brincar como um processo formativo, que contribui significativamente em seu desenvolvimento integral e aprendizagens. Neste sentido, indaga-se de que forma o brincar e os brinquedos auxiliam na construção da cultura infantil das crianças da comunidade de Arraiol? Objetivou-se analisar o brincar, os brinquedos e brincadeiras para compreender como essas práticas sociais e culturais influenciam na constituição e valorização da cultura infantil do contexto investigado. A metodologia fundamentou-se no paradigma qualitativo, no uso da história oral, que analisa o contexto a partir das narrativas dos sujeitos, para compreender os fenômenos sociais em foco.

\section{0 contexto da comunidade de Arraiol}

A comunidade de Arraiol é uma vila de ribeirinhos que fica localizada na zona rural do município de Macapá, capital do estado do Amapá, mais precisamente na zona Norte do Arquipélago do Bailique, distrito que está situado no leste do estado brasileiro do Amapá. O 
distrito do Bailique dista 160 a 180 quilômetros da capital, Macapá. São cerca de 7 mil habitantes espalhados pelas 8 ilhas do arquipélago (Brigue, Curuá, Faustino, Franco, Igarapé do Meio, Marinheiro e Parazinho). Com cerca de 40 comunidades e 1.700 quilômetros quadrados de área, incluindo água e continente (IBGE, 2016).

A Vila Progresso, é a maior e mais estruturada das ilhas do arquipélago, trazendo com isto alguns problemas sociais como as drogas e a marginalidade, o que dificilmente é visto em comunidades com menos influências urbanas, geralmente as mais afastadas e menos populosas. A comunidade de Arraiol possui suas características peculiares, uma comunidade pequena, na qual a sabedoria, união e força de vontade se fazem presentes como principais características desse grupo.

Arraiol, está localizada em uma das áreas mais afastadas do Arquipélago, um pouco mais próxima do oceano Atlântico, tanto é, que em determinadas épocas do ano, em tempos de maré alta, pode se sentir o gosto salgado do oceano nas águas do rio. Conhecida e marcada por sua religiosidade católica, Arraiol tem sua comunidade base que se manifesta em seus cultos dominicais, nas novenas, nos terços, na festividade anual em honra ao santo padroeiro, nas visitas pastorais, enfim, em uma série de atividades envoltas ao fazer cristão.

Por ser uma comunidade mais afastada, sofre poucas influências do brincar urbano, na qual preserva muitos saberes e brincar da terra, bem como brinquedos do chão, feitos com elementos naturais, aproveitados da própria natureza, tendo como exemplo os bois de coco ou de cuia, que são feitos pelos pais ou pelas próprias crianças, com os quais elas brincam de "curralzinho" imitando os pais em suas tarefas diárias, neste caso o cuidar dos bois.

Em seus escritos, Lopes (2007), destaca que a comunidade possui diversas conquistas, que foram conseguidas por meio de muita batalha. Conta com o projeto viveiro florestal, uma biblioteca comunitária, posto de saúde comunitário, cantina comunitária, associação de moradores, além do centro de vocação tecnológica (CVT) - agro biodiversidade do Bailique, que acontece na modelagem da Pedagogia da Alternância, um embrião da escola família agroextrativista do Bailique, na comunidade do Arraiol, gestada pelo Ministério de Ciência, Tecnologia, Inovação e comunicação do Governo Federal e coordenada pela Universidade Federal do Rio Grande (FURG).

\section{As Culturas Infantis ribeirinhas}

A cultura infantil é socialmente produzida pela criança com base em tudo o que a 
cerca, principalmente em seu ato de brincar. Nesse processo, a criança estabelece relações, seja com os adultos, com outras crianças ou com os elementos materiais pertencentes ao seu meio social. A cultura infantil também se revela como fator fundamental na formação da identidade do meio em que a criança está inserida, podendo ser considerada parte do patrimônio imaterial da comunidade.

Neste sentido, Dewey (1976), acreditava que há íntima relação entre a experiência e a educação, porém, não basta a existência da experiência, mas a qualidade da mesma, isto é, as experiências precisam ser positivas, pois, nem toda experiência é educativa, havendo aquelas que podem produzir dureza, insensibilidade, incapacidade, restringindo, portanto, a possibilidade de outras experiências mais ricas.

Também, para Vigotsky, (2007) o desenvolvimento e a aprendizagem estão sempre relacionados, por meio do ambiente físico e social a criança inicia seu aprendizado bem antes de chegar no espaço escolar, com os conhecimentos derivados de experiências pessoais, concretas e cotidianas, que são chamados de conceitos cotidianos espontâneos.

$\mathrm{Na}$ mesma linha de pensamento, Gilles Brougère (2012), analisa o brincar como fenômeno cultural em uma perspectiva sociológica. A cultura lúdica, em suas características, diz respeito a relação da criança com a cultura em uma ótica antropológica, investigando desenvolvimento físico, evolução material e cultural, costumes sociais, características raciais, crenças etc.

Para Carvalho e Ferreira (2006) a cultura do ribeirinho, a sua maneira de se expressar corporalmente, é influenciada pelas suas experiências e como ele interpreta e se posiciona diante desses fatores. O trabalho exercido, predominantemente rural, e a forma de brincar das crianças trazem particularidades ao cotidiano dessas comunidades e influenciam a dinâmica de suas práticas e na construção da cultura. Deste modo, a cultura das crianças ribeirinhas é muito corporal, e abrange a maneira como eles se relacionam e se manifestam no mundo objetivamente e subjetivamente, no sentido de revelar a sua consciência e sua história, por meio da motricidade (CARVALHO; FERREIRA 2006).

Arenhart (2016, p. 147) considera que "a natureza da atividade do brincar, por si só, já é um espaço privilegiado de produção cultural da infância, pela possibilidade que as crianças têm de, por ela, experimentar, reproduzir e recriar a realidade e suas regras". Compreende-se que é principalmente por meio da brincadeira que a criança vai construindo sua visão de mundo e estabelecendo relações sociais.

Toda criança é socializada em um determinado meio cultural e suas brincadeiras não surgem do nada, ao contrário são frutos da sociedade em que está inserida e são repletas de 
significações, geralmente as brincadeiras costumam imitar a forma de vida dos indivíduos da sua cultura, como o trabalho de homens e mulheres e o convívio familiar, e mesmo aquelas crianças que utilizam brincadeiras que nada tem a ver com sua realidade, conseguem expressar seus sentimentos, anseios, suas vontades e fantasias (FRIEDMANN, 2013).

\section{Procedimentos metodológicos}

A investigação fundamentou-se no paradigma qualitativo, com o uso da metodologia denominada História oral. De acordo com Meihy (2002, p. 13), “a história oral é um recurso moderno usado para elaboração de documentos, arquivamento e estudos referentes a experiência social de pessoas e de grupos, é sempre uma história do tempo presente e também reconhecida como história viva". Adotou-se este modelo de pesquisa por considerar que a história oral é uma técnica que responde aos objetivos no tipo de estudo que foi proposto, pois, analisa o contexto, a partir das narrativas dos sujeitos, para compreender os fenômenos sociais em foco.

Para análise das narrativas foi feito o uso da técnica denominada análise do discurso, por ser uma abordagem social construcionista de pesquisa, adotando uma posição crítica no que diz respeito aos modos convencionados através dos quais entende-se o mundo e a nós próprios, isto é, modos que usamos para interpretar o mundo, no qual as análises interpretam a investigação do brincar com a terra no enfoque da cultura infantil. Considera-se que esses modos de compreensão foram edificados por meio de processos sociais, que portanto, são histórico e culturalmente específicos (COYLES, 2010).

De acordo com os princípios éticos para pesquisa com seres humanos em que se deve resguardar as identidades das pessoas, as crianças bem como os adultos tiveram sua identidade mantida em sigilo, sendo que durante a redação das informações, ao longo da análise/apresentação dos resultados da pesquisa, os dados coletados junto aos pais ou responsáveis e comunidade, foram identificados por nomes fictícios (nomeados por siglas), definindo também o gênero. Não houve uma quantidade definida de participantes dentro do universo populacional do local, já que a adesão à pesquisa se deu de forma voluntária, respeitando as condições de acessibilidade ou conveniência dos moradores, conforme Gil (2008).

As imagens ou narrativas dos participantes que aparecem no trabalho, estão devidamente autorizadas por meio de termo de consentimento livre e esclarecido, e o projeto 
foi devidamente submetido e aprovado pela Plataforma Brasil. O número do CAAE 87078518.4.0000.0003, identifica o respaldo para o pesquisador, demonstrando que o projeto teve o parecer de aprovação pelo comitê de ética e também é uma segurança para as pessoas envolvidas na pesquisa.

\title{
4 A natureza como espaço de fomento das Culturas Infantis ribeirinhas: narrativas dos moradores da comunidade de Arraiol
}

Os resultados parciais, foram colhidos durante os primeiros contatos com o lócus da pesquisa, com base nas vivências, por meio da observação não participante e dos relatos dos moradores. Nesse contato, foi possível presenciar algumas práticas culturais do brincar, muitas delas bastante tradicionais, assim como os brinquedos feitos de materiais que são extraídos diretamente da natureza e da terra. Por ser um lugar de biodiversidade muito rica e diversa, porém, sem brinquedos industrializados, as crianças usam sua criatividade, criando e recriando cultura, brincam com todo e qualquer tipo de elemento material que está ao seu alcance.

Os adultos contribuíram com relatos sobre o brincar. Em uma das narrativas acerca das boas lembranças que tem da sua infância na comunidade e de como observa o brincar de hoje das crianças, P1, participante do sexo feminino revelou:

\begin{abstract}
Não tinha outro brinquedo que a gente pudesse invejar naquela época, porque era aquilo que todas as crianças tinham, e gosto de ver criança brincando, porque eu acredito que a melhor lembrança que a gente guarda com perfeição da vida da gente, é a da infância, quase nada é ruim na nossa infância, tudo é muito gostoso de ser lembrado [...] Não é mais aqueles brinquedos da nossa época, mas eles ainda brincam sim, e muito, as meninas a gente ainda vê, brincando de boneca, brincam bastante, até bem grandinhas mesmo, os meninos são mais a parte de futebol, brincam de montaria, aí pela beira, remando [...] Eles brincam muito com bola, com barquinhos de madeira, pulando na água, nadando, fazem o futi-lama deles na beirada aí, parquinho, pira alta, pira esconde, pira pega, pira ajuda, vôlei, queimada [...] Todas essas brincadeiras (P1, relatos de pesquisa, 2018).
\end{abstract}

No contexto de um país plural como o Brasil, é salutar que se evidencie as peculiaridades culturais existente em cada canto da sociedade. Estas não podem ser tratadas com indiferença, mas valorizadas, pois fazem parte do arcabouço histórico brasileiro. Propiciar acesso à cultura é fundamental para o crescimento do indivíduo, daí a necessidade de valorização dos mais diversos aspectos culturais, seus costumes, suas artes, suas crenças 
para compreender a sociedade em que se vive. Nesse sentido, conforme Brandão (2002) depreende-se que, ao se vivenciar uma cultura, é possível conviver com e dentro de um tecido, cenário dinâmico, viver uma cultura é estabelecer em si e com os outros a possibilidade do hoje. Consiste tanto de valores simbólicos, imaginários que representam o patrimônio espiritual de um povo.

Em uma conversa com P2, participante do sexo feminino, acerca das brincadeiras da sua infância, e das brincadeiras mais tradicionais presentes na comunidade, relata:

Da minha infância, não me lembro muito, não me lembro até porque era mais difícil negócio de brincadeira na minha infância, eu tinha que ajudar muito os meus pais, mais na roça que nós trabalhava na época. Na minha infância mesmo né, era difícil brincadeira... só nadando em cima de aningueira, de boia de aninga, era o que nós brincava também... É uma árvore que tem no mato, a gente corta e faz boia dela pra nadar em cima, ela boia, foi em cima do que eu aprendi a nadar, em cima de aninga (P2, relatos de pesquisa, 2018).

Santos, evidencia as dificuldades que enfrentou na sua infância, por precisar trabalhar para ajudar seus pais acabou privando-se dos momentos de brincar. Entende que por se tratar de outro tempo histórico, não se pode fazer uma análise atual, pois essa análise deve ser feita de acordo com o tempo em que o indivíduo viveu, qual era o ideal de sociedade, as visões de mundo, etc. $\mathrm{O}$ que se sabe é que as crianças eram mobilizadas para ajudar nos meios de subsistência, no sustento da família. P3, participante do sexo feminino, também comentou sobre as crianças da comunidade, e seu cotidiano.

Elas são muito chegadas a brincar na água, na água e na ponte, como diz, elas vivem pra lá e pra cá, conversando, batendo papo umas com as outras, de vez em quando elas dão uma entrada aqui na biblioteca, dão uma mexida aí, leem um pouco, e brincam no parquinho também lá, que foi feito pra eles né. Aquele parquinho lá, ele era na frente da escola estadual, lá na outra ponta da comunidade, mas como a gente viu que ele ficava muito isolado, porque pra lá a escola terminava ali, e não tinha ainda outras casas, aquelas outras famílias não tinha, então quando terminava as aulas, ficava muito isolado e era perigoso deixar a criança pra lá, aí a gente trouxe aqui pro meio da comunidade, pra frente da igreja, porque todos que passam ali, tão observando, fica mais seguro pra eles, as vezes as crianças brigam, não é frequente mas muitas vezes acontece né. Aí foi trazido pra cá e eles se divertem muito, esse parquinho aí tem muita história, não só com as crianças da comunidade, mas com crianças que, os pais são filhos da comunidade e que moram em Macapá, e quando é nas férias ele vêm pra comunidade, principalmente nas férias de final de ano. E o parque é sonho deles, se ficar feio eles reclamam (risos), tem que ajeitar de vez em quando (P3, relatos de pesquisa, 2018). 
Nota-se que os adultos dessa comunidade, reconhecem a importância do brincar das crianças, incentivam e auxiliam, e sempre zelam pelos pequenos, não considerando a brincadeira como mero passatempo. Além disso, as crianças de Arraiol demonstram ter uma imaginação muito fértil, pois são capazes de criar e modificar objetos a partir do imaginário

Em Sarmento (2004), compreende-se que o lúdico faz parte do contexto social do adulto e da criança, no entanto, esta é uma característica central das culturas infantis, pois, é brincando que as crianças constroem sua visão de mundo, sua aprendizagem, interpretam, criam, recriam, e constroem relações sociais. Enquanto que para os adultos, a brincadeira é apenas uma forma de distração. E, por fim, a fantasia, se constitui como uma característica particular do mundo da criança. Através da imaginação as crianças constroem novas possibilidades, experimentam novas sensações, criando situações, amigos imaginários, transformando objetos em algo de seu interesse, a fantasia é um fator essencial nas culturas infantis.

No decorrer dos relatos, as brincadeiras tradicionais vão sendo rememoradas, em algumas é possível visualizar exatamente como eram ainda hoje no brincar das crianças, outras vão sofrendo diversas modificações, até que se transformem por completo ou fiquem apenas na memória.

Um dos principais elementos que as crianças utilizam para brincar é o próprio corpo, quando jogam bola, quando sobem em árvores, quando brincam na lama, nas cantigas de roda, o nadar no rio, andar de montaria, dentre outros. Dessa forma o corpo se torna parte da constituição da cultura infantil.

As bonecas feitas de cachos de açaí, de bacaba ou de espigas de milho, os barquinhos de madeira, ou de casca de melancia, e muitos outros são brinquedos sazonais (dependentes do verão e da roça), como o contato com a comunidade foi feito no inverno, não se tem imagens de alguns brinquedos, porém, foram relatados pelos moradores nos primeiros contatos com a comunidade. Alguns ainda são feitos com frequência, outros nem tanto. Segue o relato do brincar de P5, participante do sexo masculino que reside na comunidade:

A gente brincava muito de carrinho, a gente construía nossos carrinhos, de lata de conserva, sardinha, óleo, a gente montava, pra fazer o carro queria, o pneu era de sandália, fazia as ruas, aquela extensão de chão, tudo capinado, era dia e noite (P5, relatos de pesquisa, 2018).

As brincadeiras antigas, são constantemente lembradas na comunidade, por mais 
que algumas estejam caindo no esquecimento, percebeu-se que há uma preocupação, principalmente por parte dos professores e líderes da igreja que relataram que as cantigas de roda tradicionais e as brincadeiras são valorizadas e relembradas, ano após ano, como bem continua afirmando P5, : “A do uruá, nós fizemos ano passado, do jacarandá foi esse ano, todo ano há um resgate". P6, participante do sexo masculino, também corrobora afirmando:

\begin{abstract}
$\mathrm{Na}$ escola, eu brinco muito de cantigas de roda com eles, eles adoram brincar no rio, na lama mais ainda, de escorregar, e nas festas de quadrilha, a gente brinca de passar fogueira, passa fogueira, brinca de comadre, afilhados, e fica cantando músicas, vai rodando na fogueira e usando o nome dos santos, dá três rodas e aí no final a gente já é compadre, já é afilhado (P6, relatos de pesquisa 2018)
\end{abstract}

Enquanto na vida urbana cada vez mais se vive a era do consumismo, as roupas e a ostentação são a forma de dizer, onde o indivíduo se localiza na pirâmide social. Nessa comunidade, as crianças só se vestem de si mesmas.

$\mathrm{Na}$ parte lateral do barquinho feito de madeira, está escrito o nome da criança, precedido da contração "Comte.", que significa comandante. Seu avô informou que a criança pediu para que o seu nome fosse escrito no barco, provavelmente a criança com seu barquinho quis imitar o que vivencia no seu cotidiano, que são os microempresários que trabalham no transporte de passageiros da capital para o distrito.

O brincar "simplificado", é o suficiente para as crianças da comunidade de Arraiol, porque no simples, se encontra grandes riquezas culturais, basta que se compreenda essas riquezas, pois, o importante mesmo é brincar. Neste sentido, Hall (2002), faz uma crítica com relação a identidade no cenário atual, centrando-se na perda gradual do que se chama de identidade cultural, por conta da vida urbana e a cultura de massa, padrão este que contém símbolos e interesses universais, tais como o culto a marcas famosas, o consumismo e a busca de uma beleza padrão. Assim, a homogeneização e a fragmentação do sujeito e de sua identidade cultural, afetam diretamente a identidade das culturas híbridas.

Destarte, Geertz (1989) atenta para a ampliação do conceito de cultura para uma dimensão mais justa, não se deve tentar defini-la, reduzi-la, isso significa padroniza-la, não há como categorizar a cultura em uma estrutura facilmente compreensiva. Defende um conceito de cultura semiótico, isto é, que estuda os fenômenos culturais, desse modo afirma que a cultura é pública e o comportamento humano é uma ação simbólica, assim como a forma que uma sociedade toma, é reflexo substancial da cultura deste povo. Portanto, a 
cultura se configura como incompleta, como uma ciência estranha, em constante modificação.

Candau (2012) corrobora afirmando, que nesta relação globalização versus multiculturalismo como nova forma de globalização, as lógicas são compostas, as relações e movimentos não podem ser vistos de modo simplificado, a convivência social, no contexto de um mundo globalizado, busca padronização, enquanto que no campo do multiculturalismo, a busca é pela compreensão e respeito pelas particularidades culturais e as diferenças.

\section{Algumas considerações}

Com base em análises que foram feitas através de estudos já realizados acerca do brincar ribeirinho, para embasamento teórico do próprio estudo aqui presente, observa-se que há algumas pesquisas envolvendo temáticas relacionadas ao brincar e a culturas infantis em comunidades ribeirinhas ou tradicionais, porém, há uma escassez em se tratando da Amazônia Amapaense, mais especificamente no Arquipélago do Bailique e principalmente envolvendo as culturas infantis, ou a infância como um todo, os poucos estudos existentes, geralmente se voltam para a comunidade geral. O estudo da cultura infantil se torna bem mais escasso, comprovando que ainda é uma realidade pouco conhecida, reconhecida e valorizada como patrimônio cultural, apesar de muito rica.

De fato, ainda no Brasil contemporâneo, são presentes práticas etnocêntricas empobrecedoras que perduram em todo o cenário social, também conhecidas como práticas hegemônicas ou colonizadoras. A compreensão errônea do processo engessado de formação intelectual da criança, é histórica, devido o arrastar de pensamentos e necessidades que sempre se mantiveram envoltos as crianças, percebendo-as como seres a espera de algo, o ser adulto para servir o mercado de trabalho, e não seres em uma etapa de vida. Os estudos iniciais revelaram que Arraiol é uma comunidade muito rica em saberes e fazeres do brincar, nesse processo de aprender e ensinar, tendo como elemento central o brincar, percebeu-se que as crianças criam e recriam suas próprias culturas, modificando aquilo que elas aprendem e dando significados próprios, deixando ali registrado sua identidade.

É a busca pela desconstrução desse discurso monocultural arraigado nos indivíduos e pela valorização das diferenças e reconhecimento do outro que o texto dialoga, sugerindo reflexões acerca desta problemática. Mas para que o caminho seja positivo, é necessário o reconhecimento da cultura infantil, bem como a valorização do brincar e da infância e 
rebeldia contra o universo de preconceitos e discriminações presentes na sociedade brasileira. Assim é possível se situar de maneira crítica, de modo a promover experiências de interação com o outro, articulando igualdade e ao mesmo tempo o respeito ao diferente.

\section{Referências}

ARENHART, Deise. Culturas infantis e desigualdades sociais. Petrópolis, RJ: Vozes, 2016.

BRANDÃO. Carlos Rodrigues. A Educação como cultura. Campinas: SP: Mercado das Letras, 2002.

BROUGÉRE, G. A criança e a cultura lúdica. In: KISHIMOTO, T. M. [Org]. O brincar e suas teorias. São Paulo: Cengage learning, 2012.

CANDAU, V.M. (Org.) Didática crítica intercultural: aproximações. Rio de Janeiro: Vozes, 2012.

CARVALHO, N.; FERREIRA, N. Práticas lúdico-corporais de crianças ribeirinhas. Disponível em: <http://citrus.uspnet.usp.br/eef/uploads/arquivo/71 Anais 349.pdf>. Revista Brasileira de Educação Física, São Paulo, Esp. v. 2 0, p.349-76, set. 2006. Suplemento n. 5. Acesso em: 19. jan. 2018.

COYLES, A. Análise do discurso. In: Métodos de pesquisa em psicologia. 3. ed. Porto Alegre: Artmed, 2010.

DEWEY, J. Experiência e educação. São Paulo: Companhia Editora Nacional, 1976.

FRIEDMANN, Adriana. Linguagens e culturas infantis. São Paulo: Cortez, 2013.

GEERTZ, Clifford. A interpretação das culturas. Rio de Janeiro: LTC,1989.

GIL, Antonio Carlos. Métodos e técnicas de pesquisa social. 6. ed. São Paulo: Atlas, 2008.

HALL, Stuart. A identidade cultural na pós modernidade. 7. ed. Rio de Janeiro: DP\&A, 2002. 
INSTITUTO BRASILEIRO DE GEOGRAFIA E ESTATÍSTICA (IBGE). Amapá.

Disponível em: < https://cidades.ibge.gov.br/painel/historico.php?codmun=160030> Acesso em: 27 jan. 2018.

LOPES, José Cordeiro dos Santos. Arraiol do Bailique: uma história de resistência cabocla. 2017.

MEIHY, José. Carlos Sebe Bom. Manual de História Oral. São Paulo: Edições Loyola, 2002.

SARMENTO, Manoel Jacinto. As culturas da infância nas encruzilhadas da $2^{a}$ modernidade. In: SARMENTO, Manuel Jacinto; CERISARA, Ana Beatriz. Crianças e miúdos: perspectivas sociopedagógicas da infância e educação. Porto, Portugal: Edições ASA, 2004. Disponível em:

< http://www.andreaserpauff.com.br/arquivos/disciplinas/brinquedosebrincadeiras/4.pdf >. Acesso em: 12 jan 2018.

VYGOTSKY, L. S. A formação social da mente: o desenvolvimento dos processos psicológicos superiores. 7 ed. São Paulo: Martins Fontes, 2007.

recebido em 21 jun. 2018 / aprovado em 01 out. 2018

Para referenciar este texto:

BRANDÃO, P. P. N.; BRITO, Â. C. U. Vamos brincar na terra? Uma experiência de valorização e resgate da cultura infantil com moradores da comunidade de Arraiol na Amazônia Amapaense. Dialogia, São Paulo, n. 30, p. 121-132, set./dez. 2018. Disponível em: $<$ https://doi.org/10.5585/Dialogia.n30.8825>. 


\title{
A escolha profissional na perspectiva do estudante do ensino técnico de nível médio
}

\author{
Professional choice in the perspective of the high school technical
}

education student

\begin{abstract}
Nonato Assis de Miranda
Doutor em Educação pela Universidade Estadual de Campinas. Coordenador do Programa de Pós-Graduação em Educação - PPGE da Universidade Municipal de São Caetano do Sul, Coordenador do Curso de Pedagogia da Universidade Paulista. São Paulo - SP - Brasil mirandanonato@uscs.edu.br

Mateus Reis Santos Bolsistas Cnpq Programa de Iniciação Científica Ensino Médio. ETEC Jorge Street / Universidade Municipal de São Caetano do Sul. São Paulo - SP - Brasil mateustuxa@hotmail.com
\end{abstract}

Arcy Pires Piagetti Junior Mestrando em Educação na Universidade Municipal de São Caetano do Sul. Professor do Centro Paula Souza. São Paulo - SP - Brasil arcy.junior@etec.sp.gov.br

Resumo: o objetivo desta pesquisa foi identificar as motivações das escolhas profissionais de um grupo de adolescentes, bem como as intervenções do meio familiar nesse processo. Trata-se de uma pesquisa de natureza qualitativa realizada com adolescentes concluintes do Ensino Técnico de Nível Médio cujos resultados mostram que dentre os motivos que levaram as adolescentes a realizar a escolha profissional destaca-se a realização pessoal, mas o retorno financeiro esteve bastante presente, principalmente, na perspectiva das orientações parentais. A despeito da variedade de novas carreiras no mercado, esse aspecto não sobrepôs às carreiras mais tradicionais na hora da decisão das adolescentes, contudo, a influência familiar foi decisiva nesse processo. Ademais, a formação técnica de nível médio, segundo as participantes, não garante um bom emprego, é necessário ter um curso superior que facilitará a inserção delas no mercado de trabalho. Esse resultado permite fazer duas considerações: a) a preferência pela profissão em nível superior sobrepõe à de nível médio; b) a escolha da carreira continua tendo influência do núcleo familiar mesmo quando os adolescentes afirmam o contrário.

Palavras-chave: Adolescência. Ensino Técnico de Nível Médio. Escolha Profissional.

Abstract: the objective of this research was to identify the motivations of the professional choices of a group of adolescents, as well as the interventions of the family environment in this process. It is a qualitative research carried out with adolescents who completed the Secondary Technical Education whose results show that among the reasons that led the adolescents to make the professional choice stands out personal fulfillment, but the financial return was very present, especially from the perspective of parental guidance. Despite the variety of new careers on the market, this aspect did not overlap with the more traditional careers at the time of the adolescent's decision, however, the family influence was decisive in this process. In addition, the high school technical formation, according to the participants, does not guarantee a good job, it is necessary to attend an undergraduate course that will facilitate their insertion in the labor market. This result allows us to make two considerations: a) the preference for the profession at the higher level overlaps with the middle level; 
b) career choice continues to be influenced by the family nucleus even when adolescents claim otherwise.

Keywords: Adolescence. Secondary Technical Education. Choose Professional.

\section{Introdução}

A escolha profissional representa um momento crucial na vida do adolescente porque implica numa decisão que requer esboçar um projeto de vida, questionar valores, habilidades, bem como o que se gosta de fazer ou, até mesmo, o estilo de vida que se pretende ter (QUEIROZ; MOURA; VILLACHAN-LYRA, 2013). Esse cenário é desafiador para o adolescente cujo horizonte tende a agravar-se, na medida em que, "no contexto de trabalho contemporâneo" surgem "centenas de profissões, enquanto que muitas outras deixam de existir" (ALMEIDA; MAGALHÃES, 2011, p. 206).

Em geral, isso ocorre porque "A noção de trabalho configura-se não mais como uma progressão contínua e hierárquica dentro de uma organização, pois outras necessidades se impõem no mercado de trabalho" (ALMEIDA; MAGALHÃES, 2011, p. 206). Ademais, na perspectiva de Bauman, o mercado deixou de ser "aquela modernidade sólida e do capitalismo pesado" (BAUMAN, 2001, p. 76).

Esse panorama pode complicar a vida dos estudantes que, nem sempre, estão preparados para tomar decisões sérias porque, além de jovens e com pouca iniciativa, ficam angustiados diante da escolha profissional ou, até mesmo, "deprimidos, estressados, com dificuldade para sair da casa dos pais e definir seu próprio caminho" (WEINBERG, 2001).

Para minimizar essa situação, seria necessário que os pais compreendessem que a escolha profissional se dá na adolescência, cujo período é marcado por muitas transformações pelas quais seus filhos passam. Em razão disso, precisariam considerar que, embora sejam inúmeros os fatores a considerar nesse momento, deve-se ter em mente que a "[...] escolha tem que trazer realização pessoal", já que "não adianta escolher uma profissão que garanta alta remuneração" se por trás disso vier o sacrifício para exercê-la (PEREIRA, [20-?], p. 2).

Diante do exposto, questiona-se: será que para ter sucesso, dinheiro e reconhecimento é, inevitavelmente, necessária a formação superior? Ou ainda, será que, ao escolher uma carreira, o estudante poderia optar por algo que, realmente, goste ou teria que tomar uma decisão com base em outros fatores?

Esses questionamentos são importantes porque é sabido que, famílias com uma carreira em comum, de advogados, por exemplo, ou as (famílias) de baixa renda, mas que 
têm integrantes bem-sucedidos profissionalmente, em geral, tendem a influenciar mesmo que, sutilmente, seus filhos na escolha profissional.

Nesse caso, frases como: "essa profissão dá dinheiro", "o que importa é o bolso" ou até mesmo "quem faz o que gosta está pobre, pois não ganha dinheiro algum" são ditas pelos pais, irmãos ou pessoas próximas aos adolescentes com o intuito de persuadi-los acerca da escolha profissional.

Grosso modo, essas pessoas dão esse tipo de conselho desconsiderando que a autorrealização pode ser mais importante do que o retorno financeiro, pois, se não houver prazer com relação à profissão escolhida, o adolescente poderá frustrar-se tanto profissional quanto pessoalmente.

Os fatores econômicos são importantes e o ideal é que não sejam desconsiderados na ocasião da escolha profissional (MELO, 1994), mas "é preciso estar atento ao fato de que a identificação que cada um possui com uma profissão é um fator determinante para que essa escolha seja feita de forma assertiva" (CHIOCCA; FAVRETTO; FAVRETTO, 2016, p. 21).

A despeito dos inúmeros estudos (YOUNG; FRIESEN; BORYCKI, 1994) e pesquisas (YOUNG et al. 2001), por exemplo, apontando as contribuições da família no processo de escolha profissional, há controvérsias acerca dessa participação.

Para Silva (1996), a escolha profissional do jovem reativa as escolhas dos pais, acarretando, assim, antigos conflitos que muitas vezes não foram superados. Esse momento pode ser encarado pelos pais como uma possibilidade de reparação das próprias escolhas. Isso sugere que o jovem seja o depositário de fantasias inconscientes da família e, dessa maneira, cabe-lhe realizar aquilo que a família não realizou ou mesmo dar continuidade às tarefas já desenvolvidas por eles (SILVA, 1996).

Ao tomar uma decisão sobre a sua carreira profissional, a reação da família do adolescente causa impactos, sejam eles positivos ou negativos, no próprio adolescente, sendo elas sutis ou não. Portanto, por mais que a escolha feita pelo filho não satisfaça a expectativa depositada pelos pais, o apoio deles é importante para o bom relacionamento familiar. Além disso, o suporte dos pais ajuda o adolescente, que nessa fase da vida, procura alguém para ter como suporte (GONÇALVES, 1998).

Contudo, a reação negativa dos pais diante da escolha profissional do filho pode acarretar afastamentos e brigas entre os membros da família o que, por sua vez, gera mais insegurança ao adolescente podendo, inclusive, levá-lo a procurar apoio com pessoas não qualificadas para esse fim. 
Assim, considerando as proposições ora apresentada, o objetivo desta pesquisa foi investigar as concepções de alunos do curso de Ensino Técnico Integrado ao Médio (ETIM) em Administração acerca da escolha profissional.

\section{Os Desafios do Adolescente diante da Escolha Profissional}

Os desafios do adolescente para escolher uma profissão são muitos porque "[...] o desenvolvimento de carreira ocorre de modo não linear ao longo da vida" já que essa escolha ocorre na "[...] adolescência, período da vida repleto de significativas alterações fisiológicas e psíquicas, bem como em termos de papeis sociais" (ALMEIDA; SILVA, 2011, p. 75).

$\mathrm{O}$ adolescente, em geral, se vê numa situação bastante angustiante porque não está amadurecido o suficiente para tomar uma decisão dessa natureza (MIRANDA, 2006; MIRANDA; TRUFEN; BARROS FILHO, 2007). Isso ocorre porque as variáveis que compõem esse tema demandam análise crítica (SILVA; PACHECO, 2016) sendo que, nem sempre, eles e suas famílias estão preparados para esse tipo de demanda.

Com relação à questão da 'vocação', na perspectiva psicanalítica, por exemplo, é sabido que, "O problema é bastante profundo, porque, em última análise, deve-se considerar por que as pessoas fazem alguma coisa, em lugar de não fazer nada" (BOHOSLAVSKY, 2015, p. 48). Ademais, se a escolha profissional diz respeito a um planejamento de vida, é oportuno destacar que ela se remete a projeções complexas já que o "futuro implica desempenhos adultos e se trata [...] de um futuro personificado" (BOHOSLAVSKY, 2015, p.28). Nesses termos, "as escolhas profissionais têm linhas de contorno específicas nas diferentes fases de vida do sujeito" sendo que, [...] "em se tratando do indivíduo adolescente, a projeção futura referenciada num adulto exerce influência em sua escolha presente" (SILVA; PACHECO, 2016, p.2).

Diante do exposto, questiona-se: o que se deve levar em conta na hora de se fazer uma escolha profissional? Seriam as habilidades individuais, os interesses, as expectativas sociais ou quem sabe, ceder às pressões feitas pelos pais e escolher aquela profissão que eles julgam promissora? Destaca-se que essa possibilidade não é incomum, conforme apontado na pesquisa de Santos (2005) que investigou o papel da família e dos pares na escolha profissional.

São raros os casos em que os adolescentes se preocupam em discutir e se informar com antecedência acerca de qual seria o melhor caminho a seguir. A maior parte deles 
prefere, em geral, adiar o problema para a última hora levando-os a desistir dos cursos escolhidos nos primeiros semestres (LEMANN, 1999).

Segundo Macedo (1998), isso pode ser evitado, pois o jovem pode enfrentar a questão da escolha profissional sem grandes sofrimentos. Para tanto, seria necessário entender como a escolha de uma profissão é feita; quais os instrumentos condutores para determinada profissão de que cada jovem dispõe e como poderiam ser avaliados os interesses, aptidões, competências e potencialidades de cada pessoa por ocasião de sua escolha profissional. Ademais, a história de vida do sujeito da escolha dever ser levada em consideração por entender que uma escolha profissional não é construída nem acontece de um momento para outro, ao contrário, solidifica-se com o tempo (MACEDO, 1998).

Do mesmo modo, Whitaker (1997) considera a escolha como algo inerente à pessoa e não como uma vocação no sentido de um chamado irresistível para uma determinada profissão, conforme sugerem alguns psicólogos. Para essa autora, existem aptidões, interesses, características de personalidade, atitudes, valores, oportunidades educacionais dadas pelo nível socioeconômico etc., que devem ser considerados nesse momento.

Deduz-se, portanto, que as características individuais devam ser consideradas na tomada de decisão pelo adolescente quando for optar por essa ou aquela profissão.

Além disso, o adolescente, para definir seu futuro profissional, precisa considerar a situação do mercado de trabalho, as expectativas de sua família, mas sem perder de referência suas preferências individuais (BORDÃO-ALVES; MELO-SILVA, 2008; LEVENFUS, 1997; NEIVA, 1999).

Não obstante, quando ocorre a escolha profissional, na maioria dos casos, os adolescentes não estão suficientemente maduros e, nem tampouco, emocionalmente e devidamente informados para escolher uma profissão que satisfará seus interesses (SANTOS, 2005), pois muitas vezes são vítimas de um sistema educacional que, em geral, é precário (LEHMAN, 1999). Ademais, é uma fase de mudanças biopsicossociais caracterizada por transições já que “[...] durante esse período, o jovem fica num estado de desequilíbrio [...]" (LARA et al., 2005, p. 57). Nesse mesmo período “A vida cotidiana apresenta-se como uma realidade interpretada pelos homens e subjetivamente dotada de sentido para eles na medida em que forma um mundo coerente” (BERGER; LUCKMANN, 2013, p.35).

Deduz-se, portanto que o adolescente faz escolhas considerando aquelas que tenham significado e que dialoguem com seus ideais, sobretudo as que lhe tragam sentido. Assim, apesar de entender que o adolescente não tenha total clareza sobre o contexto em que se insere, ele precisa compreender que é necessário "deixar a condição atual para trás para 
ocupar uma nova" posição na sociedade (SILVA; PACHECO, 2016, p. 1). Concorda-se com esses autores, para quem, desse modo, o jovem adere aos papéis que o levará a ser como esse ou aquele adulto a quem valoriza e com o qual se identifica.

\section{Percurso Metodológico}

Esta pesquisa se caracteriza como qualitativa porque envolve abordagens interpretativas e naturalísticas dos assuntos. O pesquisador qualitativo estuda coisas em seu ambiente natural, tentando dar sentido ou interpretar os fenômenos, segundo o significado que as pessoas lhe atribuem (DENZIN; LINCOLN, 1994, p.2). Ademais, o estudo dos problemas da pesquisa, nesse caso, aborda "os significados que os indivíduos atribuem a um problema social ou humano" (CRESWELL, 2014, p.49-50).

Os dados foram coletados por meio de entrevista semiestruturada realizada com cinco estudantes do sexo feminino da $3^{\text {a }}$ série do ETIM em Administração de um colégio de São Caetano do Sul cujo tamanho da amostra foi definido pelo método da saturação que, segundo Glaser; Strauss (1967) apud Fontanella; Ricas; Turato (2008, p.18), originalmente consiste na "constatação do momento de interromper a captação de informações (obtidas junto a uma pessoa ou grupo) pertinentes à discussão de uma determinada categoria dentro de uma investigação qualitativa sociológica".

Por sua vez, a avaliação da saturação teórica a partir de uma amostra foi feita por um processo contínuo de análise dos dados, começado já no início do processo de coleta. Tendo em vista as questões colocadas aos entrevistados, que refletem os objetivos da pesquisa, essa análise preliminar buscou o momento em que pouco de substancialmente novo aparecesse, considerando cada um dos tópicos abordados (ou identificados durante a análise) e o conjunto dos entrevistados (FONTANELLA; RICAS; TURATO, 2008).

\section{A Escolha Profissional em Discussão}

Com relação à escolha profissional, das cinco entrevistadas, apenas uma não tinha, à época, uma decisão formada sobre o assunto. As demais desejam seguir carreira em nível superior (economia, direito, arquitetura, comunicação social).

A opção por dar continuidade aos estudos em nível superior deu-se porque, na concepção das participantes $(\mathrm{P})$, esse nível de ensino é mais especializado e cria melhores condições para a inserção futura, no mercado de trabalho. Em geral, elas compararam a 
formação em nível superior com a recebida em nível médio, conforme o depoimento apresentado a seguir:

[...] os cursos técnicos facilitam muito a vida das pessoas para arrumar um emprego bom (sic), mas não é como um curso superior que faz uma pessoa se especializar no que ela quer; o curso técnico é mais focado no emprego; eu não gostaria de ficar somente com o curso técnico, en quero fazer um curso superior (P1).

Destaca-se que a opção por um curso de nível superior pode estar atrelada ao retorno financeiro já que, no Brasil, a taxa de retorno da educação é relativamente elevada, da ordem de 12,9\%, tendo declinado desde o final da década de 1970 (MENEZES-FILHO, 2001 apud BARTALOTTI; MENEZES-FILHO, 2007). Não obstante, esses autores advertem que inúmeros estudos têm apontado que o comportamento das taxas de retorno da educação varia consideravelmente dependendo do nível educacional, de acordo com a oferta e demanda relativas por mão-de-obra dos diferentes níveis possíveis de instrução.

Isso induz pensar que o ensino superior traga um retorno financeiro maior que a formação em nível médio porque "[...] a educação superior, ao contrário dos níveis anteriores, tem um caráter mais profissionalizante e é subdividida em diversos cursos" (BARTALOTTI; MENEZES-FILHO, 2007, p. 488).

Essa perspectiva dialoga com a opinião dessa participante: "[...] no Brasil, principalmente, você precisa ter um curso que te deixa mais estável e o ensino superior é o minimo que as empresas estão pedindo, então você precisa ter o curso superior e vários cursos técnicos, não apenas o curso técnico" (P2).

Se por um lado, as exigências por formação em nível superior são muitas, por outro, o retorno financeiro para quem tem esse nível de formação é grande e diferenciado por cursos (NARITA; FERNANDES, 2001). Cada especialidade desenvolvida no ensino superior parece possuir demanda e oferta específica (BARTALOTTI; MENEZES-FILHO, 2007).

Esse ponto de vista corrobora a fala dessa participante que vê o assunto da seguinte forma: "para você seguir uma carreira, não pode ficar somente com o conbecimento técnico, tem que fazer alguma coisa em ensino superior; superior é uma coisa bem importante se você quer progredir na vida" (P.3).

A despeito do reconhecimento do curso técnico de nível médio, o ensino superior ainda é visto como solução para facilitar a inserção profissional no mercado de trabalho. Ocorre que "O técnico te ajuda a entrar no mercado de trabalho mais cedo; mas o ensino superior te dá mais capacidade para fazer o que quiser [...] eu acho que o ensino superior é um pouco melhor...” (P3) que o médio, opina uma estudante. 
Com relação à influência familiar sobre a escolha profissional, a pesquisa mostra que esse fenômeno ocorre direta ou indiretamente, mas não há ressentimento por parte dos participantes que veem isso como uma forma de orientação importante, conforme ilustrado nesse depoimento:

[...] primeiramente eu disse que queria fazer sociologia, mas meus pais me pediram para pegar (sic) alguma coisa que pelo menos você possa ganhar dinheiro; eu peguei alguma coisa que tem pelo menos o mesmo bloco de matérias principais; como um pouco de matemática aplicada; porque ai eu consigo trabalhar em empresa, no setor público ou em pesquisa por isso escolhi economia (P1).

Destaca-se que esse tipo de intervenção, quando feito de forma harmônica, pode ser positivo. Portanto,

[...] para cobranças dos pais, por vezes declaradas e, em outros momentos, sutis e veladas, ressaltando que quando o vínculo pais-filhos é harmonioso e verdadeiro, as opiniões parentais são valorizadas e até aceitas, sem a mera submissão dos adolescentes e, então, a família é sentida como fonte de apoio e sustentação (ANDRADE, 1997 apud ALMEIDA; MELOSILVA, 2011, p. 78).

Contudo, às vezes, os pais mostram-se inseguros frente à escolha da carreira dos filhos cuja insegurança despertada neles pode repercutir na decisão dos adolescentes a exemplo do que ocorreu com uma das participantes da pesquisa que pretendia cursar sociologia, mas em decorrência da influência familiar escolheu economia (OLIVEIRA, 2005).

Em razão disso, essa participante entende que "[...] de certa forma tem apoio da família, mas de certa forma eles estão me cortando (sic) um pouco porque en queria mesmo é fazer sociologia porque não sou boa em exatas não" (P1).

Esse tipo de influência não é positivo podendo inclusive gerar frustrações futuras à adolescente em relação à escolha profissional. Ademais, foi desconsiderado que:

As crises vivenciadas pelo adolescente e sua família incluem oscilações em sua definição profissional, indagações quanto à escolha de uma profissão rentável e segura, mas que não satisfaz, ou a opção por uma atividade que atrai, mas que não traz estabilidade financeira (SANTOS, 2005, p. 59).

Essa situação induz pensar que, ao invés de influenciar sua filha a escolher um curso de nível superior que pudesse trazer estabilidade financeira, o ideal seria que eles (os pais) pudessem reviver seus próprios conflitos da adolescência e apoiá-la em sua escolha.

Grosso modo, pode-se afirmar que a influência familiar manifesta-se como fator determinante na escolha profissional, mas o apoio e o aconselhamento adequados não criam 
uma barreira entre pais e filhos como acontece quando há mais críticas do que apoio. Assim, a certeza do rumo a seguir se torna maior por parte do estudante tendo em vista que a decisão deu-se mais por consentimento do que por pressão.

Mas, por vezes, a opinião das famílias é ignorada em razão de que o adolescente desconsidera as orientações recebidas optando por uma profissão com base em suas concepções. Mas, isso é raro, pois, em geral, eles evitam o conflito, postergando a decisão, conforme essa fala:

[...] to (sic) pensando em fazer arquitetura, mas ainda não é certeza... [...] meus pais me apoiaram, mas preferiam que eu fizesse engenharia... [...] é porque engenharia além de ganhar mais dinheiro tem melhores condições de mercado, mas como ainda não é certeza eu apenas ignorei, ainda penso em fazer arquitetura (P4).

Nota-se, portanto, que essa futura arquiteta mesmo diante da alegação dos pais de que cursar engenharia seria mais rentável do que arquitetura, ela os contraria mantendo sua escolha pela arquitetura.

Não obstante, essa decisão não é definitiva já que ela sinalizou que ainda pensa em outras áreas, como nutrição e jornalismo.

Assim, enquanto nos exemplos anteriores os pais foram filtradores para seus filhos, seja de forma positiva ou negativa, para a futura advogada quem mais a influenciou, mesmo que de forma indireta, foi seu irmão que é formado em Direito e sócio de uma empresa de advocacia.

Em razão disso, ela verbaliza: "[...] pretendo seguir direito, porque en já tive uma base com meu irmão que é advogado, eu sempre me imaginei sendo uma advogada" (P5).

Em relação à variabilidade de profissões, apenas a participante que pretende cursar economia notou alguma diferença, afirmando que a "maior ramificação profissional" facilitou o processo de escolha, fazendo com que optasse por uma carreira que mais a agradasse. As demais não perceberam nenhuma influência nesse sentido, ou seja, a escolha profissional para elas foi algo desenvolvido com o tempo.

É oportuno destacar ainda que, para os participantes, o Curso Técnico de nível médio propiciou um conhecimento melhor sobre o mercado de trabalho sendo que, para a futura estudante de Comunicação, a disciplina de Marketing foi responsável pelo desencadeamento do interesse por Comunicação Social.

Indagadas sobre a escolha profissional nos níveis técnico e superior, as participantes sinalizaram dois aspectos que merecem destaque: o mercado de trabalho e o conhecimento. 
Com relação ao conhecimento adquirido no Curso Técnico Integrado ao Médio (ETIM), cabe frisar que as depoentes partem do pressuposto de que há equivalência entre os conteúdos ministrados nos níveis básico e superior. Esse ponto de vista está alicerçado nas concepções dos professores, pois pelo menos "é o que alguns professores falam" (P3). Ademais, para a maioria delas, o conhecimento técnico de nível médio adquirido pode facilitar o acesso do egresso do ETIM ao mercado de trabalho.

Contudo, elas consideram que "o mercado de trabalho tem exigido cada vez mais especialização" sendo necessário, portanto, "o ingresso no ensino superior". Além disso, "o ensino superior é o melhor meio de preparação para o mercado profissional porque um graduado tem mais chances" (emprego) e "melhores remunerações" (MELO, 1994) quando comparado ao ETIM (P1; P3).

\section{Conclusão}

O estudo realizado com estudantes do ETIM em Administração revelou que elas têm um bom conhecimento sobre o mercado de trabalho facilitando sua escolha profissional em nível superior.

Apesar de elas terem concluído o ensino médio e se tornado técnicas, ou seja, aptas ao ingresso no mercado de trabalho, o ensino superior é almejado pela maioria delas por entenderem que a formação em nível médio não é suficiente para o ingresso no mercado de trabalho.

Com relação à escolha profissional, a pesquisa aponta que a opinião dos pais mostrou-se preponderante sobre a decisão dos filhos seja por meio de apoio, aconselhamento ou até mesmo certa pressão. Assim, "Mesmo o indivíduo possuindo o sentimento de que escolhe livremente, a família exerce um papel fundamental nesse processo" (ALMEIDA; MAGALHÃES, 2011, p. 208). Não obstante, entende-se que por mais paradoxal que possa ser, os jovens, apesar da insegurança característica da fase adolescente em que se encontram, têm condições de fazer escolhas sejam elas orientadas ou não pela família.

\section{Referências}

ALMEIDA, F. H.; MELO-SILVA, L. L. Influência dos pais no processo de escolha profissional dos filhos: uma revisão da literatura. Psico-USF, v. 16, n. 1, p.75-85, jan./abr. 2011. 
ALMEIDA, M. E. G. G.; MAGALHÃES, A. S. Escolha profissional na contemporaneidade: projeto individual e projeto familiar. Revista Brasileira de Orientação Profissional, v. 12, n. 2, 205214, jul.-dez. 2011.

BARTALOTTI, O.; MENEZES-FILHO, N. A relação entre o desempenho da carreira no mercado de trabalho e a escolha profissional dos jovens. Econ. aplic., São Paulo, v. 11, n. 4, p. 487-505, out./dez. 2007.

BAUMAN, Z. Modernidade Líquida. Rio de Janeiro: Jorge Zahar, 2001.

BERGER, P. L.; LUCKMANN, T. A construção social da realidade: tratado de sociologia do conhecimento. Tradução de Floriano de Souza Fernandes. 35. ed. Petrópolis, Vozes, 2013.

BORDÃO-ALVES, D. P.; MELO-SILVA, L. L. Maturidade ou imaturidade na escolha da carreira: uma abordagem psicodinâmica. Avaliação Psicológica, v. 7 n. 1, p. 23-34, abr. 2008.

BOHOSLAVSKY, R. Orientação vocacional: a estratégia clínica. 13. ed. São Paulo: Martins Fontes, 2015.

CHIOCCA, B.; FAVRETTO, L. H.; FAVRETTO, J. Escolha profissional: fatores que levam a cursar uma segunda graduação. ReCaPe Revista de Carreiras e Pessoas, São Paulo, v. VI, n. 1, jan./fev./mar./abr. 2016.

CRESWELL, J.W. Investigação qualitativa e projeto de pesquisa: escolhendo entre cinco abordagens. 3. ed. Porto Alegre: Penso, 2014.

DENZIN, N. K.; LINCOLN, Y. S. Handbook of qualitative research. London, Sage Publication, 1994. 
FONTANELLA, B. J. B.; RICAS, J.; TURATO, E. R. Amostragem por saturação em pesquisas qualitativas em saúde: contribuições teóricas. Cad. Saúde Pública, Rio de Janeiro, 24(1):17-27, jan. 2008.

GONÇALVES, C. M. A influência da família no desenvolvimento vocacional de adolescentes e jovens. Anais da $5^{a}$. Conferencia Bienal da EARA. Budapeste, Hungria, 1998.

LARA, L.D. et al. O adolescente e a escolha profissional: compreendendo o processo de decisão. Arq. Ciênc. Saúde Unipar, Umuarama, 9(1), p.57-61, jan./abr. 2005.

LEHMAN, I. P. Não sei que profissão escolher. São Paulo: Moderna, 1999.

LEVENFUS, R. S. Psicodinâmica da escolha profissional. Porto Alegre-RS: Artes Médicas, 1997.

MACEDO, R. B. M. Seu diploma, sua prancha: como escolher uma profissão e surfar no mercado de trabalho. 7. ed. São Paulo: Saraiva, 1998.

MELO, S. M. M. Orientação educacional: do consenso ao conflito. São Paulo: Papirus, 1994.

MIRANDA, N. A. Motivos da escolha profissional: um estudo com alunos calouros do curso de Pedagogia. Dissertação (Mestrado em Educação) - Universidade São Marcos, 2006.

; TRUFEM, S. F. B.; BARROS FILHO; J. Estudo comparativo acerca da escolha do curso de pedagogia em instituições particulares de São Paulo. Revista Ibero-Americana de Estudos em Educação, v. 2, n. 1, 2007.

NARITA, R.; FERNANDES, R. Instrução superior e mercado de trabalho no Brasil. Revista Economia Aplicada, São Paulo, v. 5, n. 1, p. 7-32, 2001.

NEIVA, K. M. C. Escala de Maturidade para a Escolha Profissional (EMEP): manual. São Paulo, SP: Vetor, 1999. 
OLIVEIRA, I. M. D. A. De quem é o vestibular? Articulações entre a família e a escolha profissional. In: VASCONCELOS, Z. B.; OLIVEIRA, I. D. (Org.). Orientação vocacional: alguns aspectos teóricos, técnicos e práticos (p. 61-77). São Paulo: Vetor, 2005.

PEREIRA, C. M. G. A escolha profissional do adolescente frente às demandas familiares e ao mercado de trabalho atual. [20-?]. Disponível em: $<$ http://www.eduvale.br/colegio/imprimir.php?id_editoria=\&id=528>. Acesso em: 12 dez. 2016.

QUEIROZ, E. F. F.; MOURA, R. B.; VILLACHAN-LYRA, P. Escolha da profissão: principais influencias pontuadas por estudantes do $2^{\circ}$ e $3^{\circ}$ ano do ensino médio. Anais do XIII Jornada de Ensino, Pesquisa e Extensão - JEPEX 2013 - UFRPE: Recife, 09 a 13 de dezembro. Disponível em: < http://www.eventosufrpe.com.br/2013/cd/resumos/R11121.pdf>. Acesso em: 10 set. 2017.

SANTOS, L. M. M. O papel da família e dos pares na escolha profissional. Psicologia em Estudo, Maringá, v. 10, n. 1, p. 57-66, jan./abr. 2005.

SILVA, L. B. C. A escolha da profissão: uma abordagem psicossocial. São Paulo: Unimarco, 1996.

SILVA, J. E.; PACHECO, M. M. D. Escolha da profissão do adolescente: pré-teste. Revista Científica On-line Tecnologia - Gestão - Humanismo, v. 7, n. 2, nov. 2016.

WEINBERG, C. (Org.). Geração delivery. São Paulo: Sá editora, 2001. Disponível em: $<$ http://www.saeditora.com.br/catalogo/geracao-delivery-adolescer-no-mundo-atual/>. Acesso em: 15 dez. 2016.

WHITAKER, D. Escolha da carreira e globalização. 11 ed. São Paulo: Moderna, 1997.

YOUNG, R. A. et. al. Career development in adolescence as a family project. Journal of Counseling Psychology, v. 48, n. 2, 2001, 190-202. http://dx.doi.org/10.1037/0022-167.48.2.190 
YOUNG, A. R.; FRIESEN, J. D.; BORYCKI, B. Narrative structure and parental influence in career development. Journal of Adolescence, n. 17, 173-191, 1994.

recebido em 19 out. 2017 / aprovado em 02 out. 2018

Para referenciar este texto:

MIRANDA, N. A.; SANTOS, M. R.; JUNIOR, A. P. P. A escolha profissional na perspectiva do estudante do ensino técnico de nível médio. Dialogia, São Paulo, n. 30, p. 133-146, set. /dez. 2018. Disponível em: < https://doi.org/10.5585/Dialogia.n30.8005> 


\title{
Rompendo os muros escolares
}

\author{
Breaking the school walls
}

\begin{abstract}
Adriana Salete Loss
Doutora em Educação pela Pontifícia Universidade Católica do Rio Grande do Sul. Professora Associada da Universidade Federal da Fronteira Sul. Chapecó - SC - Brasil

adriloss@uffs.edu.br
\end{abstract}

\begin{abstract}
Resumo: O texto "Rompendo os muros escolares" tem como tema central a discussão dos processos educacionais escolares, a partir das visões mono, multi e intercultural, objetivando provocar a reflexão sobre as práticas pedagógicas monoculturais e hegemônicas e sobre a necessidade da construção da resistência pedagógica por meio da educação multi/intercultural. O estudo de caráter bibliográfico, tem como foco a abordagem intercultural de Candau (2000), e em outros teóricos que fundamentam o multiculturalismo e a interculturalidade. A partir das reflexões evidencia-se que o desafio da educação intercultural está em problematizar as práticas pedagógicas e curriculares, na perspectiva de processos educativos e formativos voltados para pluralidade cultural, para a presentificação das diferenças e para a inclusão social. A educação intercultural como meio de resistência às propostas pedagógicas hegemônicas.
\end{abstract}

Palavras-chave: Educação Monocultural. Multiculturalismo. Educação Intercultural. Escola.

Abstract: The text "Breaking the School Walls" has as its central theme the discussion of school educational processes, based on the mono, multi and intercultural visions, aiming to provoke reflection on monocultural and hegemonic pedagogical practices and on the need to build pedagogical resistance by through multi / intercultural education. The study of bibliographical character, focuses on the intercultural approach of Candau (2000), and on other theorists who base the multiculturalism and the interculturality. From the reflections, it is evident that the challenge of intercultural education is to problematize pedagogical and curricular practices, in the perspective of educational and formative processes aimed at cultural plurality, for the presentiment of differences and for social inclusion. Intercultural education as a means of resistance to hegemonic pedagogical proposals.

Keywords: Monocultural Education. Multiculturalism. Intercultural Education. School.

\section{Introdução}

A presença do multiculturalismo tem desafiado os processos educacionais escolares para a educação intercultural, na perspectiva de superação das práticas pedagógicas monoculturalistas, etnocêntricas e excludentes. Pois, a pedagogia monocultural torna-se responsável, num sentido metafórico, pela construção dos "muros escolares", dos muros da igualdade nas desigualdades, dos preconceitos, das discriminações, das supervalorizações de alguns conhecimentos em detrimento de outros, dos processos competitivos, classificatórios e excludentes e da violência. 
A escola entre seus muros se institui com o poder de tornar o heterogêneo em homogêneo e as diferenças em igualdades, por meio de um discurso hegemônico. O discurso hegemônico é responsável pela divisão das classes sociais, pelas diversas formas de violência e exclusão social. Nessa perspectiva, de acordo com Gramsci (1999), existe "hegemonia" quando uma classe dominante não só é capaz de obrigar a uma classe subordinada a conformar-se a seus interesses, senão que exerce uma "autoridade social total" sobre essas classes e a formação social em sua totalidade, quando as frações de classe dominante não só dominam, senão dirigem e conduzem.

Desse modo, a proposta da educação intercultural, numa sociedade contraditória e conflitiva protagonizada pelos conflitos estruturantes (de classe), impulsiona à reinvenção dos processos educacionais como força contra-hegemônica e de resistência, na ousadia de romper com os "muros hegemônicos".

A educação intercultural, na perspectiva de Candau (2008) que se aproxima do multiculturalismo crítico de McLaren (1997), é o foco de nossas reflexões para a superação do modelo pedagógico escolar monocultural. Assim, o texto discute a emergência do rompimento dos muros escolares para a abertura, acolhimento e reconhecimento da pluralidade cultural e das diferenças, a partir de apontamentos críticos acerca das características das visões mono, multi e intercultural.

\section{Processos educacionais escolares: Entre o mono, o multi e o intercultural}

Para os Estudos Culturais, a cultura é um território de produção de significados em que entram em disputa diferentes grupos sociais, em que se constitui o jogo do poder da linguagem, do discurso, da construção da (s) identidade (s) e da (s) diferença (as). De acordo com Silva (2000), a identidade e a diferença são criadas pelos atos de linguagem do mundo cultural e social, resultantes de um processo de produção simbólica e discursiva e estão em estreita conexão com as relações de poder. Assim, a cultura passa a ser considerada como conjunto de conhecimentos, experiências e vivências singulares e plurais, que ocorrem em espaços e tempos diferentes.

A cultura é, por outro lado, a base de um forte vínculo social que nos aproxima daqueles com quem partilhamos as representações do mundo, os traços culturais em geral e os modos de se comunicar, formando um todo 'nós cultural'. Em suma, a cultura proporciona-nos uma noção de 
'nós' como membros de um grupo social que tem uma dada trajetória histórica; dá-nos a consciência de sermos continuadores dos 'outros', mas semelhantes a nós. (SACRISTÁN, 2002, p. 127-128).

Pela cultura ou culturas, o aprender e o pensar emergem e, mediatizados pela linguagem, consequentemente, geram novas construções e reconstruções das experiências individuais e coletivas. Ou, ainda, é na interação com os outros que o ser humano descobrese construtor da realidade, em que ao usar as ferramentas de sua cultura, nos seus modos de pensamento, e ao dialogar com outras culturas, se vê diante de novas possibilidades para o ser, fazer, viver, conviver e se relacionar. Assim, Sacristán (2002, p. 61) afirma: "Se a maior parte da experiência humana que assumimos na nossa biografia está alimentada através da rede da nossa socialização com os outros, isso deve-se, em grande parte, à linguagem".

Desse modo, a subjetividade humana também participa na constituição da identidade cultural do sujeito individual e coletivo. Para McLaren e Giroux (2000):

Nossas subjetividades são construídas em linguagem através do jogo de discursos e das posições de sujeito que consentimos em assumir. Os discursos não podem ser entendidos fora dos padrões institucionais, das formas de transmissão, das práticas sociais e dos interesses materiais que os caracterizam e sustentam. [...]. (McLAREN; GIROUX, 2000, p. 37).

Ainda, para estes autores o uso da linguagem é partidário e político. Isto é, a conceituação que damos para diversidade cultural, por exemplo, é constituída pela concepção de sociedade e de homem e mulher que possuímos. Se nossa concepção é acrítica podemos dizer que o respeito à diversidade se caracteriza pela atitude da tolerância entre as pessoas, os povos e as culturas. Já, numa perspectiva crítica, a diversidade cultural tem como característica, o acolhimento, o diálogo e o reconhecimento das diferenças culturais, estas permeadas pela desigualdade e pelo conflito.

Nessa direção, passamos a refletir sobre os processos educacionais escolares nas visões monocultural, multicultural e intercultural, com base nos fundamentos de Fleuri (2001, p. 48):

De um lado, o monoculturalismo entende que todos os povos e grupos compartilham, em condições equivalentes, de uma cultura universal. A visão essencialista, universalista e igualitária do monoculturalismo corre, porém, o risco de legitimar a dominação de um projeto civilizatório, que exclua ou subjugue as minorias cultuais.

Do outro lado, o multiculturalismo reconhece que cada povo e cada grupo social desenvolve historicamente uma identidade e uma cultura próprias. Considera que cada cultura é válida em si mesma, na medida em que 
corresponde às necessidades e às opções de uma coletividade. Ao enfatizar a historicidade e o relativismo inerentes à construção das identidades culturais, o multiculturalismo permite pensar alternativas para as minorias. Mas também pode justificar a fragmentação ou a criação de guetos culturais, que reproduzem desigualdades e discriminações sociais.

\subsection{A visão monocultural}

O monuculturalismo, conforme Kincheloe e Steinberg (2012), é caracterizado pelos discursos do neocolonialismo, em que os brancos são superiores aos outros de diferente cor, pela supremacia do Homem Branco; pelos discursos de igualdade na desigualdade; e, os discursos de educação assimilacionista, em que todos precisam ter acesso a cultura comum.

Nesse sentido, a concepção do monoculturalismo contribuiu para a presentificação de uma educação escolar caracterizada como:

- espaço organizado para o encontro das gerações - a escola reúne para a transmissão do conhecimento de geração a geração, numa perspectiva educacional do consenso e do conservadorismo;

-espaço do culto à cultura única - a escola incumbe-se da reprodução do pensamento dos grupos culturais dominantes;

- espaço do mundo intelectual - a emoção, os sentimentos e a afetividade entre professor e

o estudante são evitados, e a ênfase é dada ao pensamento racional e científico;

- espaço do sacerdócio docente - o educador é um sujeito vocacionado para o trabalho, considerado o "iluminado" para testemunhar a verdade e os valores morais.

Assim, para Peres (2000, p. 281), temos o professor monocultural com um perfil que:

- Considera a diversidade cultural como um obstáculo e um déficit ao processo de ensino aprendizagem;

- Defende um curriculum fechado e homogêneo, veiculando uma cultura oficial para todos - o etnocentrismo.

- Promove a competição dos alunos, criando dispositivos de compensação (educação compensatória) para os mais "fracos"/grupos minoritários.

- Reconhece e compreende as diferenças sociais e culturais, porém, desenvolve um trabalho de "manutenção".

- Ignora as vivências/experiências dos alunos, desvalorizando a educação não formal e informal.

- Permanece nas tradições liberais e conservadoras, fomentando os ghettos da escola. 
Desse modo, temos uma proposta de educação bancária, da pedagogia acrítica. A escola como reprodutora do sistema capitalista, que inculca noções de disciplina, de tempo e de trabalho produtivo, conforme Enguita (1989). Metaforicamente, a escola capitalista é o espaço em que se aprende o trabalho alienado e subserviente.

A visão monocultural, nos processos educacionais escolares, é fundamentada na concepção filosófica essencialista, que tem como objetivo o desenvolvimento do homem racional, intelectual e moral. Também, tem seus fundamentos na sociologia funcionalista, em que o trabalho escolar é a preparação para o trabalho no mercado. Nessa perspectiva, a relação educativa constitui-se de forma linear e fragmentada, em que o poder é centralizado no professor, aquele que sabe e ensina o outro (o aluno) que não sabe. A obediência ao professor é a obediência ao "chefe" para o futuro emprego, se vier a conquistar.

Assim, na sociedade brasileira, da pluralidade cultural e das desigualdades, quem serão os serviçais? Quem serão os desempregados, os excluídos, os marginalizados, os discriminados? A estas indagações é fácil de responder: são os negros, os povos indígenas, os trabalhadores assalariados, os sem teto, os sem terra; todos que a política neoliberal os rouba de seus direitos de cidadania.

\subsection{A visão multi e intercultural}

A literatura sobre Educação multicultural surge no contexto dos países anglo-saxões, e temos nos Estados Unidos, dois importantes autores que abordam a questão do multiculturalismo que são Peter McLaren e James Banks.

Peter McLaren (apud,2012, Kincheloe e Steinberg), reconhece cinco tipos de multiculturalismo; são eles: a) O Multiculturalismo conservador ou monoculturalismo; b) O Multiculturalismo liberal; c) $\mathrm{O}$ Multiculturalismo pluralista; d) O Multiculturalismo Essencialista de Esquerda; e) O Multiculturalismo Teórico. Os quatro primeiros tipos são voltados à concepção hegemônica de sociedade, acrítica aos processos educativos escolares, enquanto o último tipo se apresenta como perspectiva contra-hegemônica e crítica.

De acordo com Sabariego (2002), no contexto europeu existe um consenso geral dos autores que reconhecem o termo intercultural com a conotação diferente do multicultural.

O termo multicultural expressa simplesmente a situação real de uma sociedade com vários grupos culturais que mantêm uma certa coesão entre si a partir de alguns valores e normas. Enquanto o termo intercultural 
afirma explicitamente a realidade do diálogo, a reciprocidade, a interdependência e expressa um desejo, um método de intervenção por meio do qual a interação entre as diferentes culturas seja uma fonte de enriquecimento mútuo. (SABARIEGO, 2002, p. 74).

Assim, a interculturalidade reconhece as diferenças na diversidade cultural e constitui abertura para o etnoconhecimento e o etnosaber. A educação intercultural busca,

[...] reconhecer e valorizar as expressões culturais particulares de todos os agrupamentos humanos, não só por uma razão epistemológica, evitando assim todas as formas de etnocídio epistêmico, mas também por razões éticas e políticas, pois sem a garantia de sua identidade, as pessoas humanas não podem ser autônomas, livres e emancipadas. (SEVERINO, 2013, p. 42).

Desse modo, a educação escolar, na perspectiva da educação intercultural, se apresenta como espaço de culturas antagônicas, em que a diversidade está presentificada no individual e no coletivo. A relação intercultural emerge da singularidade e da pluralidade de concepções, ideias, valores, costumes, crenças, etc, constituindo-se na reciprocidade e no conflito. Ainda, em espaço da autonomia dos sujeitos, em que o educador compreende o educando como um ser de liberdade, ou seja, na relação educativa há a descentralização do poder, em que o diálogo problematiza as experiências culturais.

Para Sabariego (2002) educação intercultural, admite que a diversidade étnica e cultural é um elemento positivo e enriquecedor na vida de todas as pessoas e que pretendem contribuir para o educando no reconhecimento e aceitação tanto da própria identidade como reconhecer as identidades culturais dos outros.

Conforme Peres (2000), o professor/educador intercultural, tem atitudes práticoreflexivas e críticas; defende um curriculum aberto e flexível, adaptado aos contextos multiculturais; promove o diálogo e a colaboração (pedagogia interativa) com os grupos minoritários e com os grupos maioritários, defendendo um projeto social; defende a emancipação cultural e a reconstrução social; estimula a educação não formal e informal, estabelecendo pontes entre experiências anteriores à escola e os projetos curriculares; concilia a tradição com a inovação, revisitando cada vez mais os momentos mais significativos da cultura comunitária; e, defende a descentralidade da escola, em que essa instituição faz parte da comunidade.

Nessa perspectiva, Candau e Koff (2006, 489-490), pontuam alguns desafios a serem enfrentados pelos educadores para a promoção da Educação Intercultural: 
- Penetrar no universo de preconceitos e discriminações presentes na sociedade brasileira. Essa realidade se apresenta entre nós com um caráter difuso, fluído, muitas vezes sutil, e está presente em todas as relações sociais. A "naturalização" é um componente que a faz em grande parte invisível e especialmente complexa. Para a promoção de uma educação intercultural é necessário reconhecer o caráter desigual, discriminador e racista da nossa sociedade, da educação e de cada um (a) de nós. Desenvolver estratégias nessa perspectiva é fundamental.

- Questionar o caráter monocultural e o etnocentrismo que explícita ou implicitamente impregnam os currículos escolares. [...].

- Articular igualdade e diferença: é importante articular no nível das políticas educativas, assim, como das práticas pedagógicas, o reconhecimento e a valorização da diversidade cultural, com as questões relativas à igualdade e ao direito à educação, como direito de todos (as).

- Resgatar os processos de construção das nossas identidades culturais, tanto no nível pessoal como no coletivo. As histórias de vida e da construção de diferentes comunidades socioculturais são elementos fundamentais nessa perspectiva. [..].

- Promover experiências de interação sistemática com os "outros": para sermos capazes de relativizar nossa própria maneira de situarmo-nos diante do mundo e atribuir-lhe sentido, é necessário que experimentemos uma intensa interação com diferentes modos de viver e expressar-se. [...]. - Reconstruir a dinâmica educacional: a educação intercultural não pode ser reduzida a algumas situações e/ou atividades realizadas em momentos específicos, nem focalizar sua atenção exclusivamente em determinados grupos sociais. Trata-se de um enfoque global, que deve afetar todos os atores e a todas dimensões do processo educativo, assim como os diferentes âmbitos em que ele se desenvolve. No que diz respeito à escola, afeta a seleção curricular, a organização escolar, as linguagens, as práticas didáticas, as atividades extraclasse, o papel do professor, a relação com a comunidade etc.

- Favorecer processos de "empoderamento", principalmente orientados aos atores sociais que historicamente tiveram menos poder na sociedade, ou seja, menores possibilidades de influir nas decisões e nos processos coletivos. O "empoderamento" começa por liberar a possibilidade, o poder, a potência que cada pessoa tem, para que ela possa ser sujeito de sua vida e ator social. [...].

Assim, nos processos educacionais escolares, na perspectiva da educação intercultural, há o respeito, o acolhimento e o reconhecimentos dos diferentes saberes e inteligências. A pluralidade cultural, os processos de discriminação, as diferenças culturais, os preconceitos, as classes sociais, entre outros, são conteúdos emergentes para o diálogo crítico, na constituição da igualdade de direitos.

Nesse sentido, a educação multi/intercultural requer um processo pedagógico de mediação dos conflitos, em que aos sujeitos é facultada a liberdade para o diálogo, de modo a permitir a não cegueira frente ao mundo do Eu e do Nós. Assim, conforme Fontoura (2005, p. 56), "Optar pela interculturalidade significa optar por um tipo de sociedade que 
aposta na integração das diferenças. Integrar pressupõe dar a cada um, ao longo de toda a vida, a capacidade de participar ativamente no projeto de sociedade”.

\section{Considerações finais}

Os processos educativos e formativos, na perspectiva da educação intercultural, requerem uma relação educativa que instigue a socialização de experiências entre as diferentes gerações e culturas, permeada pela metodologia do conflito e da transformação. Isso significa, promover "uma relação de troca e de reciprocidade entre pessoas vivas, com rostos e nomes próprios, reconhecendo reciprocamente seus direitos e sua dignidade. Uma relação que vai além da dimensão individual dos sujeitos e envolve suas respectivas identidades culturais diferentes" (FLEURI, 2001, p.53).

Nesse sentido, a proposta da educação multi e intercultural necessita constituir espaços educativos promotores da participação, da sensibilização, da autonomia, da capacidade crítica e da ação interventiva no contexto social, pois conforme Peres (2000, p. 121):

A escola deve definir-se, cada vez mais, como um lugar de encontro, diálogo, afeto, convivência, onde todos e cada um se sintam bem e possam participar e intervir em atividades instrutivas/educativas, interessantes e estimulantes, independentemente das diferenças de raça, etnia, sexo, idade, religião, língua, cultura - uma escola aberta à negociação e à diversidade cultural, ou seja, uma escola multi-intercultural.

Assim, na perspectiva do autor a escola precisa se definir como espaço em que os sujeitos se sintam reconhecidos, incluídos e protagonistas, no sentido da cidadania intercultural.

Para tanto, é fundamental que haja a problematização das nossas concepções de ciência, de conhecimento, de educação, de escola e de cultura, para compreendermos a natureza das relações entre a cultura escolar, a cultura da escola e a cultura social, conforme Candau (2000). Também, é necessário que a escola possa romper com seus muros atentandose para o que afirma Rancière (2002, pl 25): “[...] Há embrutecimento quando uma inteligência é subordinada a outra inteligência. Ainda, ele afirma: [...] Para emancipar um ignorante, é preciso e suficiente que sejamos, nós mesmos, emancipados; isso é, conscientes do verdadeiro poder do espírito humano (2002, p. 27)”. 


\section{Referências}

CANDAU, Vera Maria; KOFF, Adélia Maria Nehme Simão e. Conversas com... sobre a Didática e a Perspectiva Multi/Intercultural. Revista Ciências da Educação - Educação \&o Sociedade, Campinas, v. 27, maio/ago. 2006.

CANDAU, Vera Maria (Org.). Reinventar a escola. Petrópolis: Vozes, 2000.

Direitos humanos, educação e interculturalidade: as tensões entre igualdade e diferença. Revista Brasileira de Educação, v. 13, n. 37, jan./abr. 2008. Disponível em: < http://www.scielo.br/pdf/rbedu/v13n37/05.pdf. >. Acesso em: 06 jun. 2018.

ENGUITA, Mariano Fernández. A face oculta na escola: educação e trabalho na escola. Porto Alegre: Artes Médicas, 1989.

FLEURI, Reinaldo Matias. Desafios à educação intercultural no Brasil. Revista PerCursos. v. 2, n. $0 . \quad$ FLORIANÓPOLIS, 2001. Disponível em: $<$ http://www.periodicos.udesc.br/index.php/percursos/issue/view/169>. Acesso em: 06 jun. 2018.

FONTOURA, Madalena. Uns e outros: da educação multicultural à construção da cidadania. Educa: Lisboa, 2005.

GRAMSCI. Cadernos do Cárcere. Rio de Janeiro: Civilização Brasileira, 1999.

HARPER, Babette; CECCON, Claudius; OLIVEIRA, Miguel Darcy de; OLIVEIRA Rosiska Darcy de. Cuidado Escola! São Paulo: Brasiliense, 2006.

KINCHELOE, Joe L.; STEINBERG Shirley R. Repensar el multiculturalismo. Barcelona: Ediciones Octaedro, 2012.

McLAREN, Peter. Multiculturalismo crítico. São Paulo: Cortez, 1997.

; GIROUX, Henry. Escrevendo das margens: geografias de identidade, pedagogia e poder. 2000. In: McLAREN, Peter. Multiculturalismo revolucionário - pedagogia do dissenso para o novo milênio. Porto Alegre: ARTmed, 2000. p. 25 a 49. 
PERES, Américo Nunes. Educação Intercultural - Utopia ou realidade? - Processos de pensamento de professores face à diversidade cultural: integração de minorias migrantes na escola (Genebra e Chaves). 2. ed. Porto: Profedições, 2000.

RANCIÉRE, Jacques. O mestre ignorante: cinco lições sobre emancipação intelectual. Belo Horizonte: Autêntica, 2002.

SABARIEGO, Marta. La Educación intercultural - ante los retos del siglo XXI. Espanha: DESCLÉE, 2002.

SACRISTÁN, Gimeno J. Educar e conviver na cultura global. Porto/Portugal: ASA, 2002.

SEVERINO, A. J. Interculturalidade, educação e encontro de pessoas e povos. In: CARVALHO, A. D. (Org.). Interculturalidade, educação e encontro de pessoas. Porto: Edições Afrontamento, 2013.

SILVA, T. T. da. (Org.). Identidade e diferença: a perspectiva dos estudos culturais. Petrópolis, Rio de Janeiro: Vozes, 2000.

recebido em 06 jun. 2018 / aprovado em 22 nov. 2018

Para referenciar este texto:

LOSS, A. S. Rompendo os muros escolares. Dialogia, São Paulo, n. 30, p. 147-156, set. /dez. 2018. Disponível em: < https://doi.org/10.5585/Dialogia.n30.8774> 


\title{
Por um currículo plural na perspectiva do multiculturalismo
}

\author{
For a pluralistic curriculum in the perspective of multiculturalism
}

\begin{abstract}
Maria das Graças Gonçalves Vieira Guerra
Doutora em Educação pela Universidade Federal da Paraíba. Professora do Centro de Educação da Universidade Federal da Paraíba. Paraíba - PB - Brasil

gracinhavieira@yahoo.com.br

Iracema Campos Cusati

Doutora na área de Didática, Teorias de Ensino e Práticas Escolares pela Faculdade de Educação da Universidade de São Paulo. Professora do Colegiado de Matemática da Universidade de Pernambuco. Recife - PE - Brasil iracema.cusati@upe.br

Kleber Ferreira Costa Mestre em Linguagem e Ensino pela Universidade Federal de Campina Grande. Professor assistente da Universidade de Pernambuco. Recife - PE - Brasil

kf.costa1@hotmail.com
\end{abstract}

Resumo: O multiculturalismo, como corpo teórico e campo político, tem sido discutido intensamente nos debates atuais. Entretanto, esse termo, polissêmico na contemporaneidade, não pode ser considerado modismo e como tal é foco da problematização nesse artigo, por gerar preocupações pelas consequências à formação de professores e à educação de futuras gerações. Inserida num contexto sociocultural, a escola produz e/ou reproduz a exclusão de vários grupos sociais, gerando insucesso e evasão. Para tal, apoiados nas reflexões apresentadas pelos teóricos, discutimos questões do cenário das políticas educacionais em função da diversidade étnico-racial, da interculturalidade e do multiculturalismo na busca de compreensão de como esse cenário pode contribuir para uma prática docente compromissada com as demandas sociais. Em tempos de choques culturais, a educação e a formação de professores não cabem se furtar quanto ao multiculturalismo, pois é premente incrementar pesquisas comprometidas com a concretização de ideais multiculturais na formação de professores e no currículo.

Palavras-chave: Multiculturalismo. Currículo plural. Escola multicultural.

Abstract: Multiculturalism, as a theoretical body and political field, has been discussed intensively in the current debates. However, this term, which is polysemic in contemporary times, can't be considered a fad, and as such is the focus of the problematization in this article, because it raises concerns about the consequences of teacher training and education for future generations. Inserted in a sociocultural context, the school produces and / or reproduces the exclusion of several social groups, generating failure and avoidance. To that end, based on the reflections presented by the theorists, we discuss issues of the educational policy scenario in terms of ethnic-racial diversity, interculturality and multiculturalism in order to understand how this scenario can contribute to a teaching practice committed to social demands. In times of cultural clashes, education and teacher training can't be avoided as far as multiculturalism is concerned, since it is urgent to increase research committed to the achievement of multicultural ideals in teacher training and curriculum.

Keywords: Multiculturalism. Plural curriculum. Multicultural school. 


\section{Introdução}

O multiculturalismo, como corpo teórico e campo político, tem sido discutido e revisitado intensamente em grande parte dos debates na atualidade principalmente pela necessidade de compreendermos a sociedade como constituída de identidades plurais, com base na diversidade de raças, gênero, classe social, padrões culturais, linguísticos e outros marcadores identitários. O multiculturalismo constitui uma ruptura epistemológica com o projeto da modernidade, no qual se acreditava na homogeneidade e na evolução natural da humanidade rumo a um acúmulo de conhecimentos que levariam à construção universal do progresso. Opostamente, entendemos por multiculturalismo a abordagem que vai além da valorização da diversidade cultural em termos folclóricos, aquela que questiona a construção das diferenças e, por conseguinte, dos estereótipos e preconceitos contra aqueles percebidos como diferentes em sociedades desiguais e excludentes (CANEN; OLIVEIRA, 2002).

Uma educação multicultural insere-se em uma visão pós-moderna de sociedade, em que a diversidade, a descontinuidade e a diferença são percebidas como categorias centrais que, contrapondo-se à percepção moderna da identidade como uma essência, estável e fixa, traz no bojo do multiculturalismo a percepção identitária descentrada, múltipla e em processo permanente de construção e reconstrução.

Considerando a polissemia do termo multiculturalismo e suas diversas abordagens, autores como Canen (1999, 2001), Canen e Grant (1999), Canen e Moreira (2001) desenvolvem reflexões para além da valorização da diversidade cultural ao questionarem a própria construção das diferenças e, por conseguinte, dos estereótipos e preconceitos contra aqueles percebidos como "diferentes" no seio de sociedades desiguais e excludentes. No caso da educação e da formação de professores em sociedades multiculturais e desiguais como o Brasil, adotar o multiculturalismo como horizonte norteador significa aceitar desafios para o currículo que deve incorporá-lo nas normativas, nos discursos e nas práticas.

Inserida neste contexto sociocultural está a escola, que produz e/ou reproduz a exclusão de vários grupos sociais, gerando problemas, dentre os quais, o insucesso escolar e a evasão. 


\section{Multiculturalismo e seus significados}

Multiculturalismo se refere a uma pluralidade cultural que convive de forma harmônica, muito embora qualquer tentativa de defini-lo seja fracassada. Segundo Werneck (2008, p. 429) o multiculturalismo "pode consistir na justaposição ou presença de várias culturas em uma mesma sociedade e também na relação entre elas". O termo costuma ser utilizado em estudos antropológicos e sociológicos que pretendem explicar como as sociedades que possuem um acervo cultural tão diverso convivem entre si. A globalização, se quisermos identificar como um processo de inúmeras culturas que interagem entre si, produz um efeito na sociedade, dita globalizada, que é uma forte tendência para eliminar diferenças, promovendo uma cultura planetária.

Diretamente afetados, os sistemas educacionais, evidenciando a formação de novos imaginários sociais, são desprovidos de referentes históricos, geográficos e temporais, caracterizados por uma forte presença da cultura da imagem que traz reflexos na educação multicultural.

No passado, o multiculturalismo refletiu em diversas civilizações com seu próprio conjunto de manifestações culturais. Quando estas civilizações interagiam entre si aconteciam vários fenômenos gerando um processo que eliminava gradualmente as diferenças e gerava uma espécie de cultura comum ao incorporar muitos dos avanços e das características culturais de outros povos. Isso fez com que o multiculturalismo criasse uma espécie de cultura que reunia elementos variados.

Hoje, com a globalização, podemos observar como um processo semelhante acontece mediado pelas profundas transformações tecnológicas e econômicas possibilitando não somente que as distâncias se tornem cada vez menores como também aproximando diferentes culturas que antes eram esquecidas. Esta circunstância se refere ao multiculturalismo que, embora apresente muitas variantes culturais de povos com histórias diferentes, também produz um tipo de homogeneidade que acontece gradualmente e de forma constante.

Historicamente, o multiculturalismo surge nos Estados Unidos, em meio a conflitos e trocas entre dois grupos, a saber: o daqueles que se encontravam à margem da sociedade capitalista e o daqueles que se consideravam hegemônicos. Nesse contexto, cujo princípio ético buscava a orientação da ação de grupos culturalmente dominados, aos quais não foi garantido o direito de preservação de suas próprias características culturais, surgiu a concepção de multiculturalismo. 
O processo de democratização do ensino, que ocorreu a partir dos anos de 1980 no Brasil, apontava para a possibilidade de elaboração e implementação de reformas educacionais e prosseguiu aos anos de 1990, incorporando ao debate, a temática do multiculturalismo com teóricos da educação alertando para a importância da inserção da referida temática pela necessidade de tornar a educação menos desigual e, portanto, mais conhecedora das diferenças. Paralelamente, na década de 1990, vivenciou a ascensão e o fortalecimento de movimentos sociais que atuaram no campo multicultural e que, por infindáveis lutas, foram conquistando políticas educacionais relevantes.

Nesse período, a educação passou a ser compreendida como um espaço específico para abordagens contra discriminações de todos os tipos e o multiculturalismo, tratado na educação - mediante a falência da modernidade - pela crítica ao passado e ao abandono dos referenciais teóricos de análise da sociedade.

Homi BhaBha (1998) adverte que a harmonia só é alcançada em condições tácitas de normas sociais construídas e administradas pelo grupo dominante, obscurecendo-se o exercício do poder. Nessa perspectiva, o multiculturalismo encoraja o crescimento da tolerância, que é por definição, o reconhecimento simplificado do outro. Assim, segundo o autor, deve haver um multiculturalismo crítico (chamado de revolucionário, ou emancipatório, ou contra hegemônico) que, tendo por base a política cultural da diferença, evidencia as contradições socioculturais. Rejeitando o preconceito, esse multiculturalismo considera as interpretações e pontos de vista do outro possibilitando, assim transformações e criações culturais. Atualmente, a crítica à hegemonização cultural, à discriminação e ao racismo se dilui num discurso orientado por uma concepção estática de cultura e que se resgatado um entendimento dinâmico de cultura, esta deixa de ser um conjunto de características rígidas transmitidas de geração em geração para ser uma elaboração coletiva que se reconstrói a partir de denominadores interculturais.

Nesse horizonte de inquietações, o propósito de identificar práticas multiculturalmente comprometidas para analisar experiências pedagógicas imbuídas de questionamentos sobre a construção das diferenças focadas em dimensões identitárias específicas, tais como raça, etnia, religião, gênero e outras, propicia articular o processo de ensino-aprendizagem a posturas desafiadoras de preconceitos com relação às mesmas.

Assim, a perspectiva teórica de nossa análise dialoga com autores que têm investigado práticas pedagógicas efetivamente comprometidas com o multiculturalismo.

O conceito de hibridização (BHABHA, 1998; MCLAREN, 2000) constitui categoria para a compreensão do multiculturalismo em práticas comprometidas com essa perspectiva. 


\section{A prática pedagógica multicultural: uma prática discursiva e híbrida}

O multiculturalismo tem sido revisitado nos debates atuais pela necessidade de promover a equidade educacional, valorizar as culturas dos alunos e colaborar para superar o insucesso escolar. Romper preconceitos contra aqueles percebidos como “diferentes" é premente, uma vez que futuras gerações precisam ser educadas com novos valores em relação ao respeito e à apreciação à pluralidade cultural, além de serem provocadas em desafio a discursos preconceituosos que constroem as diferenças.

Entretanto, assim como ocorre com outros termos na área, o multiculturalismo apresenta uma polissemia (CANEN, 1999, 2000, 2001; CANEN; GRANT, 1999; CANEN; MOREIRA, 2001), englobando posturas epistemologicamente diversas e até mesmo conflitantes.

Há no cotidiano escolar uma concepção de multiculturalismo apenas como valorização da diversidade cultural, entendida de forma banalizada e folclórica, na qual sua significação é reduzida a um adorno no currículo escolar e, por conseguinte, o termo é usado e definido para comemoração de datas especiais. Silva (2000) ressalta a necessidade de discutir seus sentidos de forma mais engajada com posturas teórico-críticas de transformação social. É fato que valorizar a diversidade cultural, sem questionamento sobre diferenças e estereótipos, pouco contribui para a transformação de uma sociedade desigual como a que vivemos. Porém, é notório que o conhecimento de ritos, tradições e modos de pensar de variados grupos contribuem para valorizar a pluralidade cultural e desafiar preconceitos. Portanto, cabe à escola identificar mecanismos históricos, políticos e sociais pelos quais são construídos discursos que reforçam e silenciam identidades, bem como lutar pela superação destes mecanismos. Do contrário, o professor continuará desenvolvendo ações de trabalhador cultural ao invés de alguém que, com conhecimento cultural, busca transformar relações desiguais e entrecruzar fronteiras culturais tanto em seus discursos quanto em suas práticas. Nesse sentido, permanente nos discursos docentes, a ressignificação do discurso pedagógico nos conduz à hibridização discursiva. Segundo McLaren (2000), a possibilidade de construção de uma linguagem híbrida, ou seja, daquela que interpenetre as fronteiras culturais, incorpore discursos múltiplos, reconheça a pluralidade e a provisoriedade de tais discursos, implica numa reinterpretação das culturas que buscam promover sínteses interculturais criativas.

A linguagem híbrida procura superar os congelamentos identitários e as metáforas preconceituosas levando a uma "descolonização" dos discursos (BHABHA, 1998). No 
processo de hibridização, os marcos discursivos dominantes e colonialistas podem ser reapresentados e definidos como novos referenciais culturais, com base no contato com as culturas plurais. Compreender a mobilidade das identidades e seu caráter híbrido e transitório converge à promoção de práticas discursivas que contemplem uma linguagem também híbrida, configurada por estratégias discursivas constituídas por sínteses culturais criativas, singulares, locais e provisórias.

\section{O currículo crítico na perspectiva da multiculturalidade}

Partindo da discussão em que a hibridização da linguagem perpassa pelos múltiplos espaços sociais gerando novos saberes, cabe apresentar o conceito de currículo entendido por Moreira e Candau (2008), que contribui para entender a educação no contexto de interculturalidade como já definida. Sendo assim, os currículos são:

[...] as experiências escolares que se desdobram em torno do conhecimento, em meio a relações sociais, e que contribuem para a construção das identidades de nossos/as estudantes. Currículo associa-se, assim, ao conjunto de esforços pedagógicos desenvolvidos com intenções educativas. (MOREIRA; CANDAU, 2008, p. 18).

O entendimento apresentado acima desmistifica uma visão de o mesmo estar relacionado a plano ou lista de conteúdo que tem que ser cumprido para se chegar a um fim inexato, para introduzir uma visão de currículo que parte da análise da sociedade, do conhecimento cultural, das relações sociais que constroem esforços, via Projeto Políticopedagógico numa abordagem socioeducativa e multicultural.

Nesse contexto, o currículo se integra a fatores socioeconômicos, políticos e culturais que trazem marcas de um contexto em si, ampliando a reflexão sobre a função do mesmo nesse tempo em que se coloca a escola no verdadeiro espaço formador e facilitador do acesso do aluno ao conhecimento e a formação de sua identidade cultural. Se, segundo Silva (1999 apud MOREIRA; CANDAU, 2008, p. 17), a pós-modernidade traz reflexões sobre a visão do presente e não do futuro; sobre o conhecimento de forma relativa e não permanente, e o estado de consciência parcial e não total, tais características apontam para uma mudança de comportamento sobre o olhar do currículo que deixa de ser rotineiro e uniforme para assumir uma expectativa dinâmica e diversificada.

O currículo, dessa forma, atua numa dimensão crítica que articula saberes relacionados à cultura de mundo com a cultura escolar, integrando conhecimentos e não desprezando-os, pois todos os conhecimentos se unificam na formação do sujeito pensante. 
Perceber a criticidade desse currículo é entender sua contribuição diante do desafio de formar homens, cidadãos, conscientes de sua função de sujeito construtor da sociedade, tendo agora o conhecimento do espaço acadêmico um papel importante, pois, ao assumir sua ressignificação, segundo Moreira e Candau (2008, p. 21), possa, esse conhecimento ser "um dos elementos centrais do currículo e que sua aprendizagem constitui condição indispensável para que os conhecimentos socialmente produzidos possam ser apreendidos, criticados e reconstruídos por todos/as os/as estudantes do país".

Se a função do currículo é formadora, historicamente ficou presa à rigidez das doutrinas alienantes e estruturalistas da classe dominante que imperou, implantando currículos-empresa, campo, comércio, fábrica, indústria, entre outros, ficando imbricada à função de servir a um grupo de interesses.

Hoje, redefini-lo, significa colocá-lo diante dos desafios da sociedade com características de transformação social e humanizante, em que sujeitos aprendem na relação com o outro e com o mundo, o que para Arroyo (2011, p. 141) significa destruir esse "critério de racionalidade" do currículo para abrir espaço para os sujeitos críticos e autônomos, pois, diz o autor, "sem sua crítica não haverá lugar para sujeitos, continuarão mantidos no ocultamento.” (ARROYO, 2001, p. 141).

Esse ocultamento citado pelo autor demonstra a não participação social que deixa a classe dominante aparecer visualizando o sentido de um currículo de interesse, sem compromisso com o social, como Arroyo cita em sua obra, reproduzindo a fala das autoridades ao povo, "vocês sem saberes, sem cultura, venham aprender dos sábios e cultos." (ARROYO, 2011, p. 141). Esse discurso da escola tradicional apresentado pelo autor sobre o currículo, confirma a ideia de que o conhecimento escolar é suficiente para a formação de um currículo de vida que considera todas as relações sociais e, que portanto, somente a escola mantém o poder de ser formadora dele, sem ao menos questioná-lo.

No contexto atual, vê-se claramente uma política educacional de resultados, um currículo constituído de avaliações externas. Parece que os espaços educativos giram em torno de mostrar resultados - como publicações - para ocultar problemas. Como reflete Arroyo (2011.), esse ocultamento é uma forma de destruir o multiculturalismo, a participação social e contribuir para o fortalecimento das antigas relações de inferioridade, cultura nacional, exclusão social, violação dos Direitos Humanos.

Segundo Jallade (2000 apud LOPES, 2004, p. 111), “o currículo é o coração de um empreendimento educacional e nenhuma política ou reforma educacional pode ter sucesso se não colocar o currículo no seu centro". Essa citação revela que não adianta mudanças do 
ponto de vista político-estrutural ou financeiro apenas, para a educação, deve-se levar em conta a perspectiva crítico-social sobre currículo que de fato direcione seu olhar para as necessidades de mudança que a sociedade almeja alcançar para esse tempo de híbridos conceitos.

O conhecimento do cotidiano, nessa perspectiva, une-se ao conhecimento formal integrando-se numa proposta de autossustentação das ideias do ser que, diante do pensamento da pós-modernidade, abre espaço para a formação da identidade, ampliando as orientações das políticas curriculares que por muito se restringem às perspectivas homogeneizantes.

Dessa forma, o currículo assume uma nova forma de integração às problemáticas da sociedade e as discussões abrem espaço para temáticas culturais como gênero, sexo, etnia, credo, tecnologia, direitos humanos, educação ambiental e outras, que embora os PCN (BRASIL, 1998) já fizessem referência através dos temas Transversais, há uma necessidade de incorporá-las mais ainda enquanto prática, vivência e mudança de atitude, pois o currículo é um espaço de disputa em que a sociedade necessita do mesmo para debater novas concepções de convivência.

Mas, como iniciar essa discussão se não for pelas experiências do cotidiano que são trazidas pelos alunos à sala de aula? É inevitável. A universidade, através do seu Projeto Político-pedagógico encontra um campo perfeito para desenvolver estratégias que lidam com a junção de natureza do cotidiano com o conhecimento sistematizado. Portanto, o currículo, para assumir a função de formador, tendo que experimentar primeiro a exploração do cotidiano como conhecimento prévio, se quiser ser verdadeiro e honesto à realidade, caso contrário, continuará a reproduzir antigas práticas, como critica Arroyo (2011, p. 125): “os currículos e o material didático carregam um déficit de experiências e têm dificuldade de reconhecer ainda as experiências sociais, nem sequer dos educandos e dos educadores como conhecimento devido, sistematizado".

Contudo, para se definir esse currículo oficial, faz-se necessário debruçar o olhar sobre alguns elementos constitutivos que marcam a universidade: o primeiro é reconhecê-la como esfera de estudos culturais que, segundo Moreira e Silva (2011, p. 114), "nas duas últimas décadas gerou um forte interesse pelo conceito de 'cultura popular' e estimulou, consequentemente, uma série de importantes esforços para teorizar a ideia do "popular". Nessa perspectiva, a universidade assume a função de pesquisadora das culturas do povo, sem esquecer os aspectos global e local do contexto atual. 
O segundo elemento diz respeito a relacionar o currículo ao contexto de pósmodernidade, em que as questões atuais são refletidas no ambiente da universidade à luz da cidadania, da participação social e dos direitos humanos, no tempo e no espaço de relações interativas e midiáticas.

E por fim, o terceiro, o mais importante para um currículo na perspectiva da formação humana, que diz respeito a libertar as vozes ocultas, daí a importância da reflexão no curso da ação ou reflexão-em-ação e o prático reflexivo (SCHÖN, 1983) e a reflexão sobre o agir do professor (MACHADO, 2004) no contexto de sala de aula, para não reproduzir estereótipos já conhecidos. Nesse sentido é importante retomar o pensamento de Moita Lopes (2006, p. 103) quando diz: "contemplar as vozes do Sul”, que são silenciadas nas salas de aula ao ponto de reprimirem desejos, expectativas e sentimentos por conta de hegemonia ditatorial entre sociedade, família e universidade historicamente constituídas.

Libertar para que a universidade desoculte o currículo oculto gerador de bullying que dá impressão de uma sociedade perfeita, de brancos, de homens, de jovens, de católicos entre outros, em um campo em que as necessidades do aluno, integram-se a todos em um espaço sem homofobia, sem discriminação de qualquer tipo, sem racismo, transformando esse “'homem modulado', o mais notável produto da sociedade moderna” (BAUMAN, 2000, p. 161), - sem perfil, descontextualizado, repetitivo e programado para ser sem "essência" - em um ser das relações pessoais e das inter-redes.

Com esses três elementos relevantes para repensar o currículo, o conhecimento e a cultura nos espaços escolares, acredita-se que se estará contribuindo para composição de uma proposta curricular de função formadora "em que o multiculturalismo apela para o respeito à tolerância e a convivência pacífica entre as diferentes culturas" (SILVA, 2010, p. 86). Uma proposta curricular, portanto, que, no contexto das teorias pós-críticas do currículo, possa fortalecer a expectativa de uma cidadania plena, pensando os problemas da sociedade e colocando o estudante em formação inicial como protagonista de sua história.

\section{Considerações Finais}

O presente estudo buscou, nas considerações teóricas sobre o multiculturalismo, potencializar uma análise das formas possíveis de concretizar um currículo multicultural. Partindo da necessidade de problematização da temática e também da proliferação do debate envolvendo Multiculturalismo, Formação de Professores e Práticas Escolares, vimos diante de uma questão fulcral - a necessidade de pensar e elaborar orientações para o currículo 
híbrido seja por exigência ou por decisão permeada pela diversidade cultural - mas que não pode se submeter, nem enquanto política, nem enquanto implementação ou avaliação, a pressupostos de normatização externos ao contexto escolar.

Espera-se que essa provocação possa potencializar também a construção de práticas pedagógicas baseadas nos universos culturais dos alunos, hibridizando o discurso escolar com outros provenientes de campos diversos fundados no multiculturalismo e numa perspectiva das diferenças. Portanto, almejamos que uma prática pedagógica multicultural, aquela que se constrói discursivamente no desafio de reconhecimento das diferenças e dos preconceitos a ela relacionados, propicie uma formação de professores multiculturalmente comprometidos.

\section{Referências}

ARROYO, Miguel Gonzáles. Currículo, território em disputa. Petrópolis, RJ: Vozes, 2011.

BAUMAN, Zygmunt. Em busca da política. Tradução: Marcus Penchel. Rio de Janeiro: Zahar, 2000.

BHABHA, Homi K. O local da cultura. Belo Horizonte: Editora da UFMG, 1998.

BRASIL. Secretaria de Educação Fundamental. Parâmetros curriculares nacionais: terceiro e quarto ciclos: apresentação dos temas transversais. Brasília: MEC/SEF, 1998. Disponível em: < http://portal.mec.gov.br/seb/arquivos/pdf/ttransversais.pdf>. Acesso em: 22 nov. 2018.

CANEN, Ana. Universos culturais e representações docentes: subsídios para a formação de professores para a diversidade cultural. Educação e Sociedade, n. 77, p. 207-227, 2001.

CANEN, Ana. Educação multicultural, identidade nacional e pluralidade cultural: tensões e implicações curriculares. Cadernos de Pesquisa, n. 111, p. 135-150, 2000.

CANEN, Ana. Multiculturalismo e formação docente: experiências narradas. Educação e Realidade, v. 24, n. 2, p. 89-102, 1999. 
CANEN, Ana; GRANT, Nigel. Intercultural perspective and knowledge for equity in the Mercosul countries: limits and potentials in educational policies. Comparative Education, v. 35, n. 3, p. 319-330, 1999.

CANEN, Ana; MOREIRA, Antônio Flávio Barbosa. Reflexões sobre o multiculturalismo na escola e na formação docente. In: CANEN, Ana, MOREIRA, Antônio Flávio Barbosa (Org.). Énfases e omissões no currículo. São Paulo: Papirus, 2001. p. 15-43.

CANEN, Ana; OLIVEIRA, Ângela M. A. Multiculturalismo e currículo em ação: um estudo de caso. Revista Brasileira de Educação, Rio de Janeiro, n. 21, p. 61-74, 2002. Disponível em: < http://www.scielo.br/pdf/rbedu/n21/n21a05.pdf/>. Acesso em: 02 jun. 2018.

LOPES, Alice Casimiro. Políticas curriculares: continuidade ou mudança de rumos?. Revista Brasileira de Educação, Rio de Janeiro, n. 26, p. 109-118, ago. 2004. Disponível em: $<$ http://www.scielo.br/scielo.php?script=sci arttext\&pid=S141324782004000200009\&lng=en\&nrm=iso > . Acesso em: 02 jun. 2018.

MACHADO, Anna Raquel (Org.). O ensino como trabalho: uma abordagem discursiva. Londrina: Eduel, 2004.

MCLAREN, Peter. Multiculturalismo revolucionário: pedagogia do dissenso para o novo milênio. Porto Alegre: Artes Médicas, 2000.

MOITA LOPES, Luiz Paulo da. Linguística aplicada e vida contemporânea. In: MOITA LOPES, Luiz Paulo da. (Org.). Por uma linguística aplicada indisciplinar. São Paulo: Parábola Editorial, 2006.

MOREIRA, Antônio Flávio Barbosa; CANDAU, Vera Maria. Currículo, conhecimento e cultura. In: BEAUCHAMP, Jeanete; PAGEL, Sandra Denise. NASCIMENTO, Aricélia Ribeiro do. (Org.). Indagações sobre currículo. Brasília: Ministério da Educação, Secretaria de Educação Básica, 2008. 
MOREIRA, Antônio Flávio; SILVA, Tomaz Tadeu. (orgs.) Currículo, cultura e sociedade. 12. ed. São Paulo: Cortez, 2011.

SILVA, Tomaz Tadeu da. A produção social da identidade e da diferença. In: SILVA, T. T. da. (Org.). Identidade e diferença: a perspectiva dos estudos culturais. Petrópolis: Vozes, 2000. p. 73-102.

Documentos de identidade, uma introdução às teorias do curriculo. 3. ed. Belo Horizonte: Autêntica, 2010. 153 p.

SCHÖN, Donald Alan. The reflective practitioner. New York: Basic Book. 1983.

WERNECK, Vera Rudge. Uma avaliação sobre a relação multiculturalismo e educação. Ensaio: aval. Pol. Pub. Educ., Rio de Janeiro, v. 16, n. 60, p. 413-436, jul./set. 2008. Disponível em: <http://www.scielo.br/pdf/ensaio/v16n60/v16n60a06.pdf>. Acesso em: 03 jun. 2018.

recebido em 14 jun. 2018 / aprovado em 22 nov. 2018

Para referenciar este texto:

GUERRA, M. G. G. V.; CUSATI, I. C.; COSTA, K. F. Por um currículo plural na perspectiva do multiculturalismo. Dialogia, São Paulo, n. 30, p. 157-168, set. /dez. 2018. Disponível em: < https://doi.org/10.5585/Dialogia.n30.8798> 
RESENHAS 


\title{
Formação de Professores no Brasil: leituras a contrapelo, de Olinda Evangelista e Allan Kenji Seki (Org.)
}

\author{
São Paulo: Junqueira \& Marin, 2017. 280 p.
}

\begin{abstract}
Eudite Fernandes Carneiro
Mestranda do Programa de Pós-Graduação em Ensino da Universidade Estadual do Sudoeste da Bahia. Bahia - BA - Brasil euditinha@,hotmail.com
\end{abstract}

A coletânea reúne textos de pesquisadores ligados ao Grupo de Estudos sobre Política Educacional e Trabalho, da Universidade Federal de Santa Catarina, que constroem argumentos por meio de "[...] uma metodologia de análise documental embasada no referencial marxista" (p.11). A obra é prefaciada por José Carlos Libâneo, que destaca a eficiente atuação do grupo na publicação de artigos e livros sobre políticas públicas educacionais, problematizadas nos oito capítulos que compõem a obra.

No primeiro capítulo, Eneida Oto Shiroma et al. discutem o reflexo das ideias neoliberais que dominaram o cenário político brasileiro no interior da escola pública, principalmente a partir dos anos 90. De maneira bastante interessante, dialogam entre o que denominam ser as nove faces da tragédia docente, quais sejam: o professor reconvertido e o professor desqualificado, o professor avaliado, o professor aprendiz, o professor multifuncional, o professor responsabilizado, o professor massificado da EAD, o professorinstrumento e o professor violentado. Para os autores, essas faces demonstram a existência de um professor reprimido frente aos protestos e demandas da categoria pela melhoria salarial e das condições de trabalho.

Cláudia Lino Piccinini e Glória de Melo Tonácio ocupam-se, no segundo capítulo, do debate educacional sobre a valorização docente, considerado meta primordial nos discursos do Estado, que ganhou destaque com a aprovação do Plano Nacional de Educação (PNE), em 2014, ao determinar diretrizes, metas e estratégias para a política educacional nos dez anos seguintes. Destacam as várias lacunas e contradições existentes nas metas do PNE, denunciam o modelo de financiamento empresarial assumido pela educação que "sob o escudo da democratização, se tornou um serviço lucrativo e pontuam que a valorização do 
professor [...] não deve significar somente aumento salarial [...], portanto, falar em valorização era e é, além de tudo, resgatar o caráter intelectual da docência" (PICCININI; TONÁCIO, 2017, p. 76). v

No capítulo três, Aline Decker faz uma intensa análise de documentos produzidos pelo Banco Mundial (BM) entre os anos de 2000 e 2014, objetivando o questionamento do seu projeto político de educação e de formação de professores na virada deste século. Alega que o BM apresenta um discurso generalista ao comparar dados educacionais dos EUA com os da América Latina e do Caribe. Destarte, a autora descortina as propostas educativas e reflete sobre as estratégias de persuasão articuladas pelo BM, representando o interesse do capital, ao conferir ao professor uma formação cada vez mais instrumental, outorgando o status de parceria ao setor privado.

Na sequência, no quarto capítulo, Maria Celma Alves complexifica, no âmbito de uma perspectiva crítica, o papel político e ideológico da Rede Kipus, especialmente nas proposições concebidas nos anos 2000, centradas no protagonismo docente e nas diretrizes vinculadas à UNESCO que, com a coordenação de Jacques Delors, constituíram a Comissão Internacional sobre Educação para o século XXI, culminando com o Relatório Delors.

Ao consultar diversas fontes, entre elas, Leis, Pareceres, Resoluções e Diretrizes, Maria Helena Michels e Kamille Vaz, no quinto capítulo, traçam um panorama histórico da educação especial, apontando as sucessivas mudanças na concepção de formação docente, iniciadas com as Diretrizes Curriculares Nacionais para o Curso de Pedagogia, de 2006, que retiram do campo da graduação as habilitações em Educação Especial. As autoras exploram, na trajetória da educação especial, as "[...] mudanças e adaptações da escola para atender aos ditames do capital" (MICHELS; VAZ, 2017, p. 164).

No capítulo seguinte, Lêda Letro Ribeiro apresenta concepções da formação inicial do professor da Educação de Jovens e Adultos (EJA), no Brasil, entre os anos 2000 e 2010. Para isso, examina diversos documentos oficiais e faz levantamento de produções acadêmicas sobre o tema, incluindo documentos publicados em Seminários Nacionais de Formação de Educadores para a EJA. A autora evidencia as disputas ideológicas e destaca os interesses do capital nas políticas voltadas a essa modalidade educativa.

O sétimo capítulo, escrito por Aline de Souza Mandeli, aborda a formação de professores no Brasil entre 2003 e 2014, período em que houve um crescimento exponencial da oferta de cursos em EAD, tanto nos setores públicos, quanto privados. A autora alega que apesar de o governo manter um discurso voltado para a democratização do conhecimento e o acesso às tecnologias, paradoxalmente as pesquisas demonstraram um 
processo de mercantilização do ensino, precarização e aligeiramento da formação docente para suprir as necessidades do capital. Mandeli apresenta dados construídos por meio da análise de documentos e discute os dados quantitativos, com foco no sistema Universidade Aberta do Brasil (UAB). Para a autora, a UAB pode ser caracterizada pela flexibilização e atendimento às demandas do mercado de trabalho

No último capítulo, Jocemara Triches, examina, em 27 universidades federais, as Diretrizes Curriculares Nacionais e suas mudanças para o curso de Licenciatura em Pedagogia. Ao analisar os documentos, procurou estabelecer relações de aproximação do projeto de formação docente aos "[...] interesses do capital para com a educação nas últimas décadas [...]" (TRICHES, 2017, p. 234). Quando discute o perfil desses licenciandos, a autora sugere que a escola e os professores são responsabilizados pelo sucesso ou não dos alunos, condição que manifesta uma concepção de docência ampliada, na ineficiência e desvalorização dos estudos e na fragmentação dos cursos.

Dentre os inúmeros motivos que levam à indicação do livro, é incontestável o teor reflexivo que a obra imprime, revelando "[...] o quadro trágico da formação e condição docente no Brasil contemporâneo” (p. 12). De fácil leitura, as produções oferecem subsídios para o debate sobre a precarização da escola e do trabalho e formação docente e levantam discussões sobre a necessidade da ruptura, do enfrentamento aos atuais modelos de políticas educacionais, “[...] entre seus conteúdos e as correlações de forças que as produziram” (p. 11), como mediadoras do processo de reprodução do neoliberalismo.

Pelos apontamentos, a leitura é indicada a professores, coordenadores pedagógicos, gestores escolares, pesquisadores da área educacional e demais interessados na temática, proporcionando ao leitor uma visão crítica sobre questões cruciais acerca da formação docente, ao evidenciar as ideologias de mercado impostas à educação, desconstruindo o discurso hegemônico da burguesia, cada vez mais estabelecida na razão instrumental da ordem societária do capital. 



\section{INSTRUÇÕES PARA OS AUTORES / INSTRUCTIONS FOR AUTHORS}





\section{ORIENTAÇÕES PARA SUBMISSÃO DE TRABALHOS À REVISTA DIALOGIA}

Além da língua oficial da Revista, o português, os textos poderão ser submetidos e publicados nos seguintes idiomas: inglês, espanhol, francês e italiano.

As resenhas devem corresponder a obras recentes de, no máximo, um ano do ano de sua publicação.

Os trabalhos submetidos à Comissão Editorial serão avaliados em relação ao mérito científico, adequação às orientações da Associação Brasileira de Normas Técnicas (ABNT) às instruções editoriais contidas neste documento.

Os textos enviados deverão ser originais e inéditos e que não seja simultaneamente postulado em outras revistas ou órgãos editoriais. Textos já veiculados em eventos científicos realizados fora do país não poderão ultrapassar um ano de sua divulgação e devem ter essa data explicitada.

A Comissão Editorial não aceitará resenhas ou artigos submetidos simultaneamente a outras publicações, nacionais ou estrangeiras.

Os autores devem submeter o texto à revisão ortográfica e gramatical antes de apresentá-lo à Revista.

Todos os artigos submetidos a revista passam pela verificação do programa CopySpider (software detector de plágio).

Se a pesquisa que deu origem ao artigo envolver seres humanos, é necessário declarar que as abordagens e os instrumentos metodológicos utilizados obedeceram aos procedimentos éticos estabelecidos para a pesquisa científica em Ciências Humanas.

À Comissão Editorial reserva-se o direito de aceitar ou não os trabalhos a ela enviados e, eventualmente, sugerir modificações ao(s) autor(es), a fim de adequar os textos à publicação.

Os artigos devem conter, no máximo, 3 (três) autores. A autoria deve ser limitada a aqueles que fizeram uma contribuição significativa para a concepção, projeto, execução ou interpretação do estudo relatado. Todos aqueles que fizeram contribuições significativas devem ser listados como coautores. O autor deve se assegurar que todos os coautores adequados e nenhum inadequado estão incluídos no artigo, e que todos os coautores viram e aprovaram a versão final do documento e concordaram em sua apresentação para publicação.

Todos os autores precisam ser identificados na plataforma de submissão online da Revista. Todos os campos do perfil dos autores devem ser preenchidos, tais como: nome 
(completo sem abreviações) instituição de vínculo (completo sem sigla), país e resumo da biografia (grau acadêmico, instituição, área de atuação, departamento).

Informar o número de Registro ORCID ${ }^{\circledR}($ Open Researcher and Contributor ID) de todos os autores. Caso não possua, fazer o cadastro através do link:

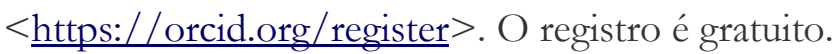

Para cada artigo exige-se que pelo menos um dos autores tenha o título de doutor.

Para submeter artigo é necessário estar cadastrado como autor na plataforma virtual da revista: http://www4.uninove.br/ojs/index.php/dialogia

Cada autor só poderá ter um manuscrito em tramitação, entre o início da submissão e a publicação final. Será observado um intervalo de dois anos entre a publicação de textos escritos pelo mesmo autor e o início de um novo processo de submissão.

O texto enviado não deve conter identificação do(s) autor(es). Para assegurar a integridade da avaliação por pares cega, para submissões à revista, deve-se tomar todos os cuidados possíveis para não revelar a identidade de autores e avaliadores entre os mesmos durante o processo.

Isto exige que autores, editores e avaliadores (passíveis de enviar documentos para o sistema, como parte do processo de avaliação) tomem algumas precauções com o texto e as propriedades do documento:

Em documentos do Microsoft Office, a identificação do autor deve ser removida das propriedades do documento (no menu Arquivo > Propriedades), iniciando em Arquivo, no menu principal, e clicando na sequência: Arquivo $>$ Salvar como... $>$ Ferramentas (ou Opções no Mac) > Opções de segurança... > Remover informações pessoais do arquivo ao salvar $>\mathrm{OK}>$ Salvar.

Os trabalhos enviados devem vir acompanhados, em arquivo separado, de formulário de autorização, (conforme modelo disponível na página virtual do periódico) sobre a exclusividade de publicação do artigo pela revista Dialogia.

A instituição e/ou quaisquer dos organismos editoriais desta publicação não se responsabilizam pelas opiniões, ideias e conceitos emitidos nos textos, sendo esses de inteira responsabilidade de seu(s) autor(es).

Todos os trabalhos serão submetidos à leitura de, pelo menos, dois pareceristas, externos a instituição originária da revista, garantindo o sigilo e o anonimato tanto do(s) autor(es) quanto dos especialistas dos pareceres. Se a avaliação de ambos os pareceristas for positiva, compete aos editores decidir da sua publicação. No caso de um dos pareceres ser negativo, o artigo será encaminhado para outro avaliador. 
O tempo médio entre a submissão do artigo e a publicação, mediado pelo processo de avaliação é de, aproximadamente, 6 meses.

As sínteses dos pareceres, em caso de aceite condicionado ou recusa, serão encaminhadas ao(s) respectivos autor(es).

Os trabalhos devem ser submetidos exclusivamente por meio da plataforma disponível no endereço eletrônico da Revista Dialogia.

\section{NORMAS BÁSICAS DE FORMATAÇÃO}

Os textos devem ser elaborados conforme as instruções a seguir.

1) Digitados no Editor Word (.doc); fonte Times New Roman; tamanho 12; alinhamento à esquerda; espaçamento 1,5.

2) Os artigos devem ter entre 14 mil e 28 mil toques (considerados caracteres e espaços), e as resenhas, entre 3,5 mil e 7 mil toques (considerados caracteres e espaços).

3) Os artigos devem apresentar os seguintes quesitos, nesta ordem:

a) Título (diferenciar maiúscula/minúscula);

b) Title: Título do artigo em língua inglesa;

c) Resumo (entre cem e 150 palavras);

Os resumos deverão ter os principais indicadores do desenvolvimento do artigo.

Obrigatoriamente, deverão conter o objeto de pesquisa, a questão de pesquisa, o modelo teórico utilizado como fundamentação, a abordagem metodológica, as categorias fundamentais e algumas das conclusões do estudo realizado, seja de caráter empírico ou meramente teórico.

d) Palavras-chave (máximo cinco, separadas e finalizadas por ponto, inicia com letra maiúscula);

e) Abstract: versão do resumo, em inglês;

f) Key-words: versão das palavras-chave, em inglês, (manter a ordem alfabética da versão em língua portuguesa);

g) Nos Indicativo de seção os números são separados por 1 (um) espaço em branco; h) Ao final, obrigatoriamente, devem ser registradas as referências de todos os autores citados no texto, apenas eles, com as informações completas. A revista adota o sistema autor-data. O recurso tipográfico utilizado para destacar o título deverá ser itálico (dúvidas consultar ABNT NBR 10520 e 6023 respectivamente).

4) As notas explicativas (não usar notas de rodapé), que não se confundem com referências à fonte, devem vir ao final do texto (antes das referências), com numeração sequencial em algarismos arábicos. 
5) As unidades de medidas devem seguir os padrões do Sistema Internacional de Unidades (SI), elaborado pelo Bureau Internacional de Pesos e Medidas (BIPM) [www.bipm.org]. Em casos excepcionais, a unidade adotada deve ser seguida da unidade expressa no SI, entre parênteses.

6) As palavras estrangeiras devem ser grafadas em itálico e os neologismos ou acepções incomuns, em fonte normal e entre "aspas".

7) Os trabalhos que exijam publicação de gráficos, quadros, tabelas ou quaisquer tipos de ilustração devem apresentar as respectivas legendas, incluindo a fonte completa. Os arquivos devem ser inseridos no texto e encaminhados separadamente e, sempre que possível, no formato original do programa de elaboração (por exemplo: CAD, CDR, EPS, JPG, TIF, XLS). As imagens devem ter alta definição (mínimo de 300 dots per inchs [DPIs]). Mapas ou micrografias devem ser representados com as respectivas marcas de escala.

Identificação das ilustrações (figuras, gráficos, quadros, imagens ) - ABNT NBR 6022:2002 - Informação e documentação - Artigo em publicação periódica científica impressa - Apresentação - item 6.9

a.São indicados na parte inferior

b.exceção das tabelas que seguem IBGE

8) Sempre que envolve imagens nas publicações da Universidade Nove de Julho é necessário autorização: do fotografado e do fotógrafo. Foto com menor tem que ter autorização dos pais também. Para requerer os formulários nos envie um e-mail.

\section{NORMAS PARA CITAÇÕES E REFERÊNCIAS}

As normas para citações nos textos a serem publicados na Revista Dialogia deverão seguir as determinações da Associação Brasileira de Normas Técnicas (ABNT).

Referencias - ABNT NBR 6023:2002 - Informação e documentação - Referências Elaboração - item 6.3

a.Alinhadas à esquerda, espaço simples

Para acesso consultar as normas na página da Biblioteca http://docs.uninove.br/arte/pdfs/manual-elaboracao-Trabahos-ABNT.pdf 